\title{
3 Análisis semasiológico
}

El objetivo de este capítulo consiste en ofrecer un panorama general de los adjetivos y adverbios en cuestión. A partir de su polisemia en la actualidad, analizaremos los cambios semánticos que conducen desde su origen léxico al valor semántico de exactitud y precisión. Además, pretendemos fechar las primeras documentaciones en el corpus para así establecer la cronología del campo semántico. En cuanto a los adverbios, analizaremos la cronología del inventario de adverbios en -mente, adverbios cortos y posibles locuciones adverbiales.

Nos basamos principalmente en nuestra muestra base estructurada en cortes de medio siglo y, para detectar las primeras documentaciones de determinados usos, volvemos al CDH (nuclear y ampliado) para buscar combinaciones léxicas relevantes. Así, nos aseguramos de citar, en la medida de lo posible, la primera documentación de cada uso en el CDH. Además, tendremos en cuenta diccionarios del latín, diccionarios históricos del francés y portugués, así como diccionarios panrománicos con el fin de detectar posibles calcos o préstamos cultos.

El análisis empírico de los cuatro pares sigue el orden cronológico de aparición de los lexemas en el corpus: mientras que justo/justamente y cabal/cabalmente se documentan ya a partir de la Edad Media, preciso/precisamente aparecen a lo largo del siglo XVI y exacto/exactamente hacia finales de este mismo siglo. Tal y como apuntamos anteriormente, queda por comprobar si el par cabal/cabalmente es el primero del grupo de los adjetivos y adverbios de exactitud.

\subsection{Justo y justamente}

En el español actual, tanto justo como justamente son polisémicos, ya que comparten una serie de significados conceptuales. Los diccionarios distinguen tres significados principales del adjetivo justo, que sirve como base léxica de los adverbios justamente y justo. El primer significado, relacionado con la justicia, es el que fue heredado del latín IŪstus 'justo, según la justicia':

El tribunal dictó una sentencia justa e irreprochable. (CLAVE 1999, s.v. justo)

Perdona misericordiosamente y castiga justamente. (Darío Fernández Flórez, Lola, espejo oscuro, 1950) ${ }^{1}$

1 Ya que ninguno de los tres diccionarios consultados ofrece un ejemplo de justamente ${ }_{1}$, citamos uno de la muestra base de nuestro corpus. 
El segundo significado es el de 'exacto'/'exactamente', es decir, el que coincide con los demás del grupo de los adjetivos y adverbios de exactitud:

Eso ha sucedido justamente como yo pensaba. (DLE 2014, s.v. justamente)

Estoy justo en medio de la calle. (CLAVE 1999, s.v. justo)

Además, hay un tercer significado, 'apretado, estrecho, ajustado’:

Este vestido viene justamente al cuerpo. (DLE 2014, s.v. justamente)

Las mangas están un poco justas. (Moliner 1998, s.v. justo)

En cuanto a las clases de palabras, se observa que justo se usa como adjetivo, como adverbio y como sustantivo:

Adjetivo: Me queda el dinero justo para llegar a fin de mes. (CLAVE 1999, s.v. justo)

Adverbio: Llegó justo cuando arrancaba el tren. (Moliner 1998, s.v. justo)

Sustantivo: Según las bienaventuranzas, los justos verán a Dios. (CLAVE 1999, s.v. justo)

Consiguientemente, justo es polisémico por combinar tres significados conceptuales y polifuncional por representar tres clases de palabras. En el caso de justamente y justo, la polifuncionalidad está condicionada por la polisemia en el sentido de que no todos los significados aparecen en todas las clases de palabras, tal y como se advierte en la Tabla 5. Llama la atención que justo 'según la justicia' solo se usa como adjetivo y - en ciertos contextos religiosos- como sustantivo, pero no como adverbio. En cambio, justo ${ }_{2}$ 'exacto, preciso' y justo 'apretado, ajustado' conocen tanto el uso como adjetivo como el uso adverbial:

Tabla 5: Polisemia y polifuncionalidad de justo y justamente.

\begin{tabular}{llll}
\hline & adjetivo & adverbio & sustantivo \\
\hline 1. 'según la justicia o razón' & justo & justamente & justo \\
2. 'exacto, preciso' & justo & justamente, justo & \\
3. 'ajustado, apretado' & justo & justamente, justo & \\
\hline
\end{tabular}

En resumen, la función básica que aparece en los tres significados de justo es la de adjetivo, mientras que el uso como sustantivo está restringido a un uso muy concreto del primer significado en el discurso religioso. Por otro lado, el uso de justo como adverbio se limita al segundo y tercer significado. El adverbio justamente, a su vez, conoce los tres significados. 


\subsubsection{El origen léxico: IŪstus en latín}

El adjetivo latino IŪSTUS, -A, -UM 'justo’ se deriva del sustantivo IUS 'derecho como conjunto de todas las leyes; pretensión legal; juzgado, tribunal' (TLL 2009, s.v. IŪSTUS; Blánquez 2012, s.v. JUSTUS). Del sustantivo IUS deriva también el verbo IURARE y, a su vez, el sustantivo IUSTITIA deriva del adjetivo IŪSTUS. Como raíz indoeuropea de IUS se han reconstruido las formas *IOUOS 'estado de regularidad, de la normalidad requerida por las reglas del ritual' (Walde 1938) o *YEWos ‘unión, ligadura, vínculo’ (García Hernández 2010, 30-31).

En el lenguaje jurídico, es decir, en una lengua de especialidad con términos técnicos propios, el sustantivo IUs 'fórmula' adquiere el uso específico de 'fórmula jurídica, derecho'; por lo tanto, IUs sufre una «tecnificación» (García Hernández 2010, 36-37, 42). Asimismo, IURARE significa en el lenguaje jurídico 'contraer un compromiso pronunciando la fórmula de unión' (García Hernández 2010, 38). Esa idea de una fórmula ritual también se prolonga en el adjetivo IŪSTUS ‘formal, ritual, convencional’ (García Hernández 2010, 39).

En este sentido, el latín IUs hace referencia a una fórmula repetida y el verbo correspondiente IURARE indica 'repetir ciertas palabras'. De modo que el significado 'justo, legítimo, según la justicia' tiene su origen etimológico en un significado más concreto y el primer cambio semántico de IUS en la época latina corresponde a la dirección general de un cambio semántico que va de concreto a más abstracto (Traugott 1988, 135).

En latín, IŪSTUS se relaciona, por lo tanto, con el ámbito jurídico y el derecho, y califica a aquello que es legítimo (TLL 2009, s.v. IŪSTUS; Blánquez 2012, s.v. JUSTUS). En el latín clásico, el significado 'justo, conforme a razón, legítimo, verdadero, debido, merecido’ está ampliamente documentado: IŪSTUS DOMINUS ‘señor legítimo' (Cicerón) (de Miguel [1867] 2000, s.v. JUSTUs; Blánquez 2012, s.v. JUSTUS: Glare 2012, s.v. IŪSTUS), IUSTISSIMA CAUSA 'causa muy justa', IUSTA BELLA 'guerras justas, legítimas', IŪSTUS HERES ‘heredero legítimo’ o IŪSTUS SUPPLICIUM 'castigo merecido' (Blánquez 2012, s.v. JUSTUs; Segura Munguía 2013, s.v. IŪSTUS). $\mathrm{El}$ adjetivo hace referencia a acciones o estados regulados y sancionados por la ley: IUSTI DIES 'el período de tiempo permitido para cumplir una comanda oficial' (Glare 2012, s.v. IŪSTUS) se corresponde, concretamente, con el 'plazo de treinta días para pagar concedido al deudor' (Blánquez 2012, s.v. JUSTUS).

Además, se usa en el sentido de 'regular, normal, ordinario': IUSTUS EXERCITUS 'ejército regular' (Segura Munguía 2013, s.v. IŪSTUS) y en el sentido de 'equitativo, razonable, llevadero': IUSTUS SERVITUS o IUSTA SERVITAS 'esclavitud suave, tolerable' (de Miguel [1867] 2000, s.v. Justus; Segura Munguía 2013, s.v. IŪSTUS). También describe un comportamiento moral de las personas: 'bueno, humilde, compasivo, imparcial’ (de Miguel [1867] 2000, s.v. JUSTUS; Glare 2012, 
s.v. IŪSTUS), como en ejemplos de tipo IUSTUS VIR 'hombre justo' (Cicerón) (Blánquez 2012, s.v. Justus; Segura Munguía 2013, s.v. IŪSTUS).

Por último, IŪSTUS también significa 'conveniente, suficiente', como en IUSTUM PONDUS ‘peso exacto’ o IUSTA FORMA 'hermosura perfecta' (Ovidio) (Blánquez 2012, s.v. JUSTUS; Segura Munguía 2013, s.v. IŪSTUS), y ‘entero, perfecto, completo’: IUSTA MURI ALTITUDo 'altura conveniente de la muralla' (Caesar) (véanse s.v. JuSTUS: de Miguel [1867] 2000; Blánquez 2012). Este adjetivo describe, pues, el tamaño, el grado o la cantidad perfectos, completos o necesarios para un fin (Glare 2012, s.v. IŪSTUS). Asimismo, el sustantivo derivado IUSTUM, -I se usa en el sentido de 'la justa medida, lo que conviene' (Blánquez 2012, s.v. JUSTUM). Nos parece probable que sea este el uso que apunta hacia el cambio semántico que dará lugar al significado de justo ${ }_{2}$ 'exacto, preciso'.

En cuanto a los usos adverbiales, existía en latín clásico el adverbio IŪSTĒ, usado en el sentido de 'justamente, con razón, equitativamente, con justicia' (TLL 2009, s.v. IŪSTUS; Blánquez 2012, s.v. JUSTE), por ejemplo, por Cicerón, y también con el significado ‘a un precio justo’ (de Miguel [1867] 2000, s.v. JUSTE). Además, ya autores como Horacio, Ovidio o Séneca usaron el matiz 'demasiado' en el uso adverbial de PLUS IUSTO o ULTERIUS IUSTO ‘más de lo justo, en exceso’ y LONGIOR IUSTO ‘demasiado largo’ (Blánquez 2012, s.v. JUSTUM).

En latín, no se documenta la perífrasis IUSTA MENTE. No aparece en la lista exhaustiva de Karlsson (1981, 145-148), ni en el TLL (2009). Sí se documentan tanto el antónimo INIQUA MENTE 'injustamente' (por ejemplo, Ovidio: INIQUA MENTE FERENDO) Como varias perífrasis con otros adjetivos de actitud que podrían considerarse sinónimos parciales de IŪSTUS: DEVOTA, HONESTA, FIRMA, GENEROSA y MODERATA MENTE (Karlsson 1981, 135-148). En este sentido, es llamativa la ausencia de documentación de IUSTA MENTE, aunque los latinistas consideran probable que tal forma se haya usado; así, por ejemplo, Müller-Lancé (2012) expone IUSTA MENTE ‘con actitud justa o razonamiento justo' como ejemplo de una perífrasis adverbial latina.

\subsection{2 ¿Origen culto o patrimonial de justo $_{1} /$ justamente $_{1}$ en español?}

En principio, los lexemas españoles de origen latino llegan por dos posibles vías: palabras directamente heredadas que se usaron ininterrumpidamente en la lengua hablada (léxico patrimonial, popular) y préstamos cultos que se retoman a través del latín escrito (semicultismos y cultismos) (Lapesa 2008, 100-102). Sin embargo, en ocasiones, el origen de una voz no se puede adscribir de manera inequívoca a una de las dos vías, ya que oralidad y escritura mantienen una interfaz compleja, por ejemplo, en el discurso religioso. Además, voces de origen 
culto pueden extenderse sucesivamente a registros populares informales en un proceso llamado coloquialización o popularización (Hummel 2019, 148).

Respecto a juste en francés y en las demás lenguas romances, von Wartburg (1948 en FEW 5, 90a, s.v. JŪSTUS) argumenta que - a pesar de que las respectivas formas puedan parecer patrimoniales- IŪSTUS fue retomado del latín escrito por las lenguas romances a raíz de la traducción latina de la Biblia a finales del siglo IV, conocida como la Vulgata. En ella, se otorgó un nuevo sentido a IŪSTUS: ‘devoto, quien cumple con las normas religiosas'. Se trata de una innovación del latín tardío cristiano, puesto que la familia léxica del latín IUs originariamente no se vinculaba a la religión (García Hernández 2010, 40). Es en el discurso religioso, donde Justus se convierte, por ejemplo, en uno de los sobrenombres de Cristo (Blánquez 2012, s.v. Justus). Asimismo, Segura Munguía (2013, s.v. IŪsTUs) apunta para el latín el uso del sustantivo IŪsTus 'justo, santo, bueno’.

A nuestro modo de ver, se trata de una especialización semántica: IŪSTUS 'correcto, quien sigue las normas (del ritual)' -igual que antes se había especializado en el discurso jurídico - se adapta al discurso cristiano, en el que las normas y las leyes las dicta Dios. Hay, pues, dos variantes contextuales de un mismo significado base: la variante contextual jurídica y la religiosa. El nuevo uso religioso probablemente radica en el poder de la iglesia como institución con alcance amplio en la sociedad medieval.

El latín IŪSTUS pasó a varias lenguas romances: francés y provenzal juste (antiguamente just, plural jusz), catalán just, español y portugués justo, italiano giusto, friulano yust, veglioto (dálmato) yost, sardo central (logudorés) yústu, así como retorromance (engadino) ğüst o yust (Meyer-Lübke 1935, s.v. JUSTUS; TLL 2009, s.v. IŪSTUS). Aunque la gran difusión de esta voz en las lenguas romances con sus diversas adaptaciones fonéticas- podría interpretarse como argumento a favor de su origen hereditario-patrimonial, que remontaría al latín vulgar, nos inclinamos por un origen culto-escrito. La gran difusión panrománica podría deberse a la influencia de la Vulgata en aquellas sociedades medievales en las que fue promovida como Biblia oficial (Enrique-Arias 2008).

Esto se confirma en el extremo oriental de las lenguas romances: el origen del adjetivo just en rumano es claramente culto y no patrimonial. Concretamente, es un préstamo del francés juste (véanse s.v. just: Marcu/Maneca 1986; Ciorănescu 2007; Vinereanu 2009) y es clasificado como «neologismo» por lexicógrafos del rumano, ya que solo aparece hacia finales del siglo XIX. El hecho de que just no se haya prestado anteriormente al rumano parece confirmar la hipótesis de von Wartburg (1948 en FEW 5, 90a, s.v. JŪSTUS) según la cual IŪSTUS no se conservó en el latín vulgar hablado, sino que el origen de sus correlatos en las lenguas romances se remonta al discurso religioso promovido por la Vulgata. Dado que esta versión latina de la Biblia no se usaba en la parte oriental de Europa, donde 
tampoco se usaba el latín como lengua culta durante el medievo, IŪSTUS no pasó al rumano antiguo. ${ }^{2}$

Según el FEW (1922-2002), el francés juste fue reintroducido por la iglesia con dicho matiz religioso y reaparece a partir del siglo XIII para materias de justicia con el significado 'correcto, bien, como tiene que ser'. Esto es, se trata de un cultismo. También el Dictionnaire historique de la langue française (= DHLF) (2000, s.v. juste) clasifica el francés juste como cultismo prestado del latín. En cambio, Corominas/Pascual (1997) defienden que justo llegó al español por la vía hereditaria (es decir: se trataría de una voz patrimonial, popular), ya que no ven razones concluyentes para considerar justo un cultismo en las lenguas romances, con la excepción del francés juste. En los apartados que siguen, analizaremos los primeros testimonios de justo y justamente en español y expondremos argumentos que apoyan la hipótesis de un origen culto, y no popular, de justo.

Ya que la tradición religiosa y la tradición jurídica son los dos ámbitos principales para la historia de la escritura en las lenguas romances, no sorprende que el uso medieval del adjetivo justo se documente ampliamente. El «efecto de corpus» favorece la atestiguación de justo. El Diccionario Medieval del Español menciona las acepciones de justo ${ }_{1}$ tanto en un contexto jurídico como religioso: 'que obra según justicia/ley’ y ‘que vive según la ley de Dios’ (Alonso 1986, s.v. justo).

Según la Enciclopedia del idioma del mismo autor, la acepción de justo (adjetivo, sustantivo) 'que vive según la ley del Dios' data del siglo XII. Un siglo más tarde reaparece el significado originario: justo (adjetivo, sustantivo) 'que obra según justicia y razón’ (Alonso 1958, s.v. justo). En este sentido, las primeras documentaciones escritas de esta voz en español corresponden al ámbito religioso y el uso jurídico - o sea: el que retoma el uso clásico- sería posterior.

En el $\mathrm{CDH}^{3}$ se recoge una primera documentación de justo ${ }_{1}$ en el siglo XII, pero es en el siglo XIII cuando su uso es documentado ampliamente. Citamos las primeras atestiguaciones en el corpus de justo como adjetivo y como sustantivo antónimo de pecador:

(1) Passado es d'este sieglo mio Cid el Campeador el día de cincuaesma, ¡de Christus aya perdón!

Assí fagamos nós todos, justos e pecadores. (Anónimo, Poema de Mio Cid, 1140 [s. XIV]) ${ }^{4}$

2 Agradezco al profesor Adrian Chircu de la Universidad de Cluj-Napoca, Rumanía, sus comentarios y su ayuda sobre aspectos del rumano.

3 Todos los ejemplos citados y enumerados en esta monografía proceden del CDH, salvo los casos en los que la procedencia se espefica en la cita (CORDE, CORPES XXI, Frantext, Google, etc.). Las negritas son nuestras.

4 Tal y como explican Rodríguez Molina/Octavio de Toledo y Huerta (2017, 11-13), el Poema del Mio Cid no se puede tomar como documentación fiel de la lengua medieval del siglo XII, ya que 
(2) Aplegos Abraam a el e dixol: «E asis perdera el justo por el peccador? Quiçab ha .l. justos en esta villa e pues matarlos as e non parçiras al logar por los .l. justos? [...]

Gozat mucho conseio de Syon e cantad la conpanna de Jherusalem; afe do verna a ti to rey iusto e salvant e affreyto, cavalgant sobre asno e sobre pollino fil de asna. (Almerich, $L a$ fazienda de Ultra Mar, 1200)

En nuestra muestra base, sacada del CDH para un análisis cualitativo y cuantitativo, gran parte de los primeros testimonios escritos de justo se vinculan al uso religioso. En los primeros períodos observados, el empleo de justo como sustantivo - que se limita al discurso religioso de 'quien vive según la ley de Dios'- predomina sobre el empleo adjetival, representando el $75 \%$ en la primera mitad y el $62 \%$ en la segunda mitad del siglo XIII.

Desde el siglo XIII, justo se documenta con ambas variantes contextuales; califica a personas que viven según la justicia y el derecho y a personas que obran según las leyes divinas y la voluntad de Dios. En el siglo XIII, la variante contextual de justo que remite claramente al significado primario relacionado con la justicia y el derecho ('que obra según justicia y razón') es minoritaria:

(3) E preguntaron-le: ¿Por qué se conosce ome que es justo? E dixo: Por que non faga cosa que venga daño a ninguno, nin fable mentira por pro de sí. E el peor ome del mundo es el que teme al derecho. E non enbidies la riqueza a aquel que non sabe bien guiar su fazienda. (Anónimo, Bocados de oro, 1250)

Ya que el uso religioso predomina desde un punto de vista cuantitativo en el corpus analizado, probablemente cuenta con una mayor difusión y profundidad histórica. La abundancia del uso religioso de justo en los primeros siglos del corpus apoya el origen religioso propuesto por von Wartburg (1948 en FEW 5, 90a, s.v. Jūstus). De ser así, el desarrollo de justo toma un desvío: en la traducción de la Vulgata de finales del siglo IV se crea un nuevo significado específico de IŪstus ('devoto, quien cumple las normas religiosas'). Este llega a las lenguas romances (con excepción del rumano) a través del latín tardío escrito, debido a la gran influencia de esta traducción bíblica. Más tarde, el español retomó o «recicló» la acepción original de IŪsTus 'correcto, según la justicia' y se trataría, pues, de un cultismo semántico que data del siglo XIII.

el manuscrito en el que se basa el texto recogido en el corpus (CORDE y CDH) es bastante posterior, del siglo XIV y cuenta con varios errores editoriales. En el Cordemáforo, esta obra recibe la etiqueta roja; por lo tanto, no consideramos fiable esta única documentación de justo en el XII. 
En conclusión, creemos que el español justo presenta una evolución paralela al francés juste: según el DHLF (2000, s.v. juste), esta palabra -igual que la familia léxica a la que pertenece - provenía originariamente del vocabulario religioso. En los primeros textos del francés, se usa en un sentido religioso ('según la justicia y las reglas divinas'), también como sustantivo, y se laiciza en el siglo XIII, cuando empieza a usarse como calificativo de personas que cumplen las leyes y las reglas establecidas por el derecho.

\subsubsection{Variación entre justo (cultismo) y derecho/derechero (voz patrimonial)}

Otro argumento a favor del origen culto de justo es la existencia de palabras patrimoniales para el concepto de 'justo, según la justicia'. Según von Wartburg (1948 en FEW 5, 90a, S.v. JŪSTUS), las palabras hereditarias medievales eran los derivados del latín DIRECTUS, es decir, de derecho en español. El sustantivo español derecho, que se documenta ya en el siglo XI, proviene del latín vulgar DERECTUS y este del latín clásico DIRECTUs (que a su vez se convierte en el cultismo directo) (Corominas/Pascual 1997). En latín, el adjetivo DIRECTUS, -A, -UM (participio de DIRIGO, DIRIGERE) se usaba en el sentido de 'que está en línea recta, recto, derecho' y, en referencia a personas, 'rígido, recto, severo' (Blánquez 2012, s.v. DIREcTUs). Asimismo, el adverbio derivado DIRECTO significaba 'en línea recta', 'directamente, sin rodeos' (Blánquez 2012, s.v. DIRECTO).

Como señala García Hernández (2010, 43-45), el sustantivo DIRECTUM (también derivado de DIRIGERE) fue sustituyendo a IUS desde el latín imperial, ya que contaba con varias ventajas: tenía más sustancia fonética que IUs y la noción de lo ‘recto’ frente a lo ‘torcido’ estaba ya presente en muchos conceptos jurídicos clásicos: «El pensamiento cristiano impulsó la idea de la ley entendida como camino recto» (García Hernández 2010, 44). El origen del significado ‘justo, correcto' en el adjetivo DIRECTUS remonta a una colocación frecuente de IUS DIRECTUM 'derecho directo, sin intermediaros'. Esta colocación fraseológica, a causa del desgaste fonético de IUS, sufre una elipsis y el adjetivo DIRECTUS absorbe el significado total. Asimismo, la colocación DIRECTO IURE ‘en derecho directo' pasa por una elipsis de IURE y, consiguientemente, el adjetivo DIRECTUS, participio sustantivado, asume el valor del sustantivo (García Hernández 2010, 44-45). ${ }^{5}$

Ya antes del fin del imperio, DIRECTUM ‘derecho’ se usaba en la lengua popular y este uso se prolonga en las lenguas romances (García Hernández 2010, 44).

5 Agradezco al profesor Jairo Javier García Sánchez de la Universidad de Alcalá de Henares que me haya llamado la atención sobre el origen y uso de DIRECTUS. 
Por tanto, el español derecho es una palabra hereditaria ${ }^{6}$ y de documentación anterior a justo. Derecho se usa también como adjetivo y, además, cuenta con un derivado adjetival anticuado: derechero. Como muestran los siguientes ejemplos, derechero y derecho son semánticamente cercanos a justo en el siglo XIII y ambas voces se entremezclan en el discurso religioso y jurídico:

(4) Apres les dixo: «Lavatvos e seed mondos, e redrat vuestras malas obras de mi e partidvos de mala, e fech bien. Mantenet iudicios derechos, e yo perdonaré vuestros pecados. (Almerich, La fazienda de Ultra Mar, 1200)

(5) Í revisclaron muchos omnes de santa vida, derecheros e justos, de creencia complida; parecieron a muchos, cosa es bien sabida, ca lo diz sant Matheo, una boca sabrida. (Gonzalo de Berceo, El duelo de la Virgen, 1236-1246)

Para ver la variación léxica entre los sinónimos justo y derechero, consultamos el corpus Biblia Medieval (Enrique-Arias 2008) que permite comparar las diversas traducciones de la Biblia al castellano durante la Edad Media. Tal y como observa von Wartburg (1948 en FEW 5, 90a, s.v. JŪSTUS), en la Vulgata el adjetivo IŪSTUS califica a personas con un comportamiento temeroso y obediente a Dios. La comparación en el corpus de Biblia Medieval muestra, por ejemplo, que la descripción de Noé como VIR IUSTUS en la Vulgata es traducida por omne derechero en la General Estoria de Alfonso el Sabio, mientras que en la Biblia Escorial del siglo XV se retoma varón justo:

(6) hae generationes Noe Noe vir iustus atque perfectus fuit in generationibus suis cum Deo ambulavit [...]. (Vulgata, siglo IV)

De Noe \& sus fi|ios \& del fecho dell arca. | II NOE |... era omne | derechero \& perfecto en sus generationes. |...| Et andido con dios \& touo se toda uia con el. | (Alfonso X, General Estoria, siglo XIII)

Estas son las genera|çiones de noe đI noe | era varon justo conpli|do en su generaçion | enlos camjnos de dios andudo | noe [...]. (Biblia Escorial I.i.3, siglo XV)

(versículo 6:9 del libro Génesis sobre Noé, corpus Biblia Medieval)

6 De nuevo, esto se confirma en otras lenguas romances como el rumano: el adjetivo drept ( $<$ derept $<{ }^{\star}$ DERECTUS $<$ lat. DIRECTUS), que equivale a los significados 'justo, legítimo, correcto, directo', es una palabra patrimonial, heredada por vía popular del latín (Vinereanu 2009, s.v. drept; Pușcariu 1975, s.v. drept) y que sigue las evoluciones fonéticas propias del rumano. La base vocálica de drept (< ${ }^{\star}$ DERECTUS < lat. DIRECTUS) es la misma del español derecho, y se diferencia del cultismo directo, que a su vez corresponde al cultismo rumano direct. De acuerdo con la regla general del rumano, el adjetivo rumano drept se usa también como adverbio, incluso ocasionalmente con el significado 'exacto' (Ciorănescu 2007, s.v. drept). 
Esa misma variación se observa en el siguiente ejemplo, en el cual los dos viRos IUSTOs de la Vulgata se convierten en varones derecheros en la traducción alfonsí y, de nuevo, en omnes justos en la Biblia Escorial:

(7) et reddat Dominus sanguinem eius super caput eius quia interfecit duos viros iustos melioresque se et occidit eos gladio patre meo David ignorante [...]. (Vulgata, siglo IV)

Y torne Dios sobre la cabeça del su pecado porque mato los dos varones derecheros y mejores que el, y matolos a espada non lo sabiendo mi padre David. (Alfonso X, General Estoria, siglo XIII)

E torne el sennor su sangre | en su cabeça que dos omnes justos \& mejo|res quel \& matolos a espada \& mj pa|dre daujd non lo sopo [...]. (Biblia Escorial I.i.3, siglo XV)

(Primer Libro de los Reyes (2:32), corpus Biblia Medieval)

Como muestran estas documentaciones, en la época alfonsí todavía se conservaba el uso preferente de la voz patrimonial derechero y derecho. Efectivamente, en el $\mathrm{CDH}$, estos superan en frecuencia a justo y justicia en los textos atribuidos a Alfonso X. ${ }^{7}$ En general, se asume que la lengua jurídica del medievo y especialmente la lengua alfonsí son los textos que mejor reflejan la oralidad de la época (Company Company 2012a, 12).

Sin embargo, el cultismo justo acaba reemplazando a la voz popular derechero: en el $\mathrm{CDH}$, este último prácticamente se limita a la Edad Media y cae en desuso. ${ }^{8}$ En el total de los textos de la Edad Media del CDH (hasta 1500), ya predomina justo sobre derechero. Por ejemplo, la combinación de los lemas ${ }^{9}$ hombre + justo da 95 resultados en el CDH y la de varón + justo 97; frente a 19 para hombre + derechero y 2 de varón + derechero. La desaparición de derechero y la sustitución de derecho/derechamente por las variantes latinizantes directo/ directamente reflejan el esfuerzo de relatinización del castellano, que favorece también la expansión de justo.

7 En el CDH, la búsqueda en los textos escritos por Alfonso X muestra las siguientes frecuencias (en el uso sustantival y adjetival): hay 168 ocurrencias de justo y 382 de justicia frente a 2028 de derecho y 227 de derechero.

8 La dispersión diacrónica de la frecuencia de derechero en el CDH es la siguiente: en la Edad Media cuenta con una frecuencia normalizada de 10,42 (por millón de palabras). Durante los siglos XVI-XVII baja notablemente a 0,23. No hay registros en los siglos XVIII y XIX, pero reaparece muy marginalmente en el siglo XX, con una frecuencia relativa de 0,04 (que equivale a tan solo 9 ocurrencias).

9 Al buscar lemas, también se incluyen formas flexionadas (plural) y ortografías antiguas como omne. Buscamos la combinación de dos lemas sin especificar el orden (ante o posposición del adjetivo). 
Consiguientemente, derechero cae en desuso a medida que justo aumenta sus contextos de uso. Justo no solo se usa en referencia al comportamiento de personas, sino que también pasa a caracterizar algo hecho según la justicia, por ejemplo, leyes. En este sentido, extiende su uso a través de una metonimia. A pesar de que Alonso (1958, s.v. justo) data el uso de justo 'arreglado a justicia y razón' en el siglo XVI, en el corpus se detecta ya en la segunda mitad del siglo XIV. Es decir, a partir del siglo XIV se recupera el uso de justo con su significado original ligado a la justicia, que se usaba ya en el discurso jurídico del latín (véase IŪSTUS 'legítimo, correcto’, apartado 3.1.1):

(8) Digo primeramente que deve ser ordenada por derecho de ley; ca como la medeçina es ordenada a provecho e salut del cuerpo humano, así las leyes justas son ordenadas a provecho e conservaçión de la comunidat, las quales deven ser comunes e todos las deven guardar e así mesmo regir e reglar por ellas. (Anónimo, Tratado de la Comunidad, 1370)

Un siglo más tarde, se observa otra extensión de uso de este adjetivo como calificativo de sucesos o hechos: la construcción [(no) ser + justo + que $]$ o $[$ ser + justo + verbo en infinitivo], que se documenta a partir del siglo XV:

(9) luego vengan al consejo corporal muy de buena mente sin entençion pecunjal non encubriendo la verdat por que al buen medico non es justa cosa. onde galieno jn primo decretiçis diebus. titulo quarto. Diziendo demostre la cosa que proue \& çierto por esperiençia sso sin preçio por que non es justo que en cubra la verdat \& çetera. (Estéfano de Sevilla, Visita y consejo de médicos, 1400)

(10) Non es justo que los ynocentes amigos de los culpados devan morir. (Anónimo, Floresta de philósophos, 1430)

(11) El comendador Lorençio Mendez dixo que si el dicho señor corregidor e regidores vieron que es justo quitar esta dehesilla a la tierra e dalla a estos o no, que se remite a ellos e hagan lo que fuere justiçia e si testimonio quisieren los labradores de la contradiçion, [...]. (Anónimo, Libro de Acuerdos del Concejo Madrileño, 1493-1497)

\subsubsection{El paradigma de los adverbios de justicia}

Tal y como apuntamos anteriormente, no se documenta en el latín tardío la perífrasis ?IUSTA MENTE, lo cual es llamativo, dado que tanto la tradición discursiva religiosa como la jurídica generalmente propulsaron el uso de estas frases adverbiales (Hummel 2013d, 231-232).

En el CDH, la primera ocurrencia de justamente 'con justicia' data de principios del siglo XIII. El adverbio aparece, pues, paralelamente a su adjetivo base, a pesar de que Alonso (1958, s.v. justamente) fecha justamente más tarde, en el siglo XVI. Originariamente, la perífrasis latina con MENTE 'mente, ánimo, intención' denotaba la actitud y el estado de ánimo del sujeto de la acción y no la acción en 
sí (Gasca Queirazza 1970; Kovacci 1999, 708-709; Company Company 2014b). En el caso de justamente ${ }_{1}$ 'según la justicia', el sufijo adverbial es semánticamente transparente, como muestra esta primera atestiguación:

(12) Cap. XX. De como deve ser el rey o prínçipe o regidor de reyno de buena abdiençia a todos los que antél venieren.

De buena abdiençia deve ser el rey o prínçipe o regidor a todos los que antél venieren, e remediarlos a todos justamente con justiçia ygual. E deve en la semana dos o tres vezes dar abdiençia al su pueblo, e ver las petiçiones por sý mesmo, porque por aý podrá saber quáles son forçadores, e robadores, e obran de malas maneras. E pueda remediar a cada uno con derecho, que quando el fecho queda en mano de dotores, lazra el que poco puede por la traydora codiçia, que les roba las conçiençias e la voluntad del bien fazer, e les faze judgar el contrario de la verdad. E quando el señor es presente e vee las cosas, el temor les faze sofrir su mala codiçia e usar justamente, quánto más sy es conoçido por justiçiero. (Anónimo, Libro de los doce sabios o Tratado de la nobleza y lealtad, 1237)

La interpretación de remediar justamente como 'remediar con espíritu justo o actitud justa' implica la actitud mental del actor de la acción, por lo que justament $_{1}$ caracteriza tanto la acción como el sujeto agente. Además, aparece en combinación con otro circunstancial de modo: con justicia igual. Asimismo, en este ejemplo se observa nuevamente la proximidad semántica con derecho: remediar con derecho. Entre los siglos XIII y XIV, el CDH registra 110 ocurrencias del lema justamente, frente a 370 ocurrencias del lema derechamente. En este sentido, en los primeros textos es notablemente más frecuente el adverbio derivado sobre la base adjetival patrimonial derecho que el derivado sobre el cultismo justo.

Otro argumento a favor de que la familia léxica de justo pertenecía al registro culto durante la época medieval es la ausencia de variación en justamente. Las variantes patrimoniales más frecuentes del sufijo -mente durante la época del español medieval eran los sufijos diptongados -mientre y -miente. Especialmente en el siglo XIII se documenta una amplia gama de variantes de este sufijo: el formativo adverbial aparece con apócope (-ment) y sin ella, sin vibrante interna y con ella (-miente/-mientre), con diptongo (-ie-) y sin diptongo (-mientre/-mentre), cohesionado con el adjetivo o separado de él, etc., siendo la variante -mente menos frecuente que -miente (Karlsson 1981; Company Company 2014b, 493, 505-506).

Estas variantes desaparecen en el siglo XIV, cuando la variante culta -mente se generaliza. Según Company Company (2012a, 28), la rápida pérdida de las variantes patrimoniales prueba el escaso arraigo de los adverbios en -mente (en cualquiera de sus variantes) en la oralidad de la época medieval. Para mediados del siglo XIV la forma -mente se había fijado y no quedan ya casi huellas de la variación formal anterior (Karlsson 1981; Chircu 2008, 174; Company Company 2014b, 506-507; 2016, 518). 
Dicha variación morfológica está plenamente documentada en derechamente, que presenta variantes como la diptongación y la - $r$-intercalada en los textos medievales:

(13) Et la otra que es pro de todos comunalmientre, es que deve jurar que judgue derechamientre a todos aquellos que a su juicio vinieren, e segund el fuero de la tierra, e que por amor, nin por desamor, nin por miedo, nin por ruego, nin por don quel den nin quel amor, nin por miedo, nin por ruego, nin por don quel den nin quel prometan nin judgue de otra manera, nin tome ruego de ninguno. (Anónimo, Leyes para los adelantados mayores dadas por el Rey D. Alonso el Sabio, 1252-1284)

Entre los siglos XIII y XIV, la variante derechamientre se documenta 113 veces en el CDH y se mantiene hasta inicios del XV. En este mismo período, se documen$\tan 108$ casos de la variante derechamente, 52 casos de la variante derechament y 40 casos de derechamiente. Esta variación ampliamente documentada, que es representativa para el panorama general de los adverbios en -mente durante el Medievo, confirma el estatus hereditario y patrimonial de derecham(i)ent $(r) e$.

Por el contrario, el cultismo justamente carece de variantes populares: la búsqueda de las formas ${ }^{\star}$ justamientre y ${ }^{\star}$ justamiente en los corpus CDH (nuclear y ampliado) y CORDE no da ningún resultado. Solo se documentan variantes apocopadas como justament y iustament:

(14) era en dannyo et periudicio dela çiudat et delos que uenian adaquella, requirjeron nos justament que nos aquella ordjnacion et los articlos contenjdos enaquella reuocassemos et no vsaremos de aquella en alguna manera, como fuesse cuentra fuero de Aragon [...]. (Anónimo, Documento de la Aljama de Zaragoza, 1331)

Según Karlsson (1981, 99-101), la forma apocopada -ment no es una forma autóctona del castellano; probablemente fue un préstamo del francés, provenzal, aragonés o catalán antiguos, ${ }^{10}$ como indicaría también el ejemplo citado, que fue redactado en Zaragoza. En este sentido, la documentación de justament podría reflejar un posible préstamo o una posible influencia del francés. Además, hay dos ocurrencias de iusta ment, cuya ortografía remite al origen perifrástico latino.

10 De hecho, el autor opina que la forma mente, en español, es la adaptación al castellano del galicismo -ment, a través de la restauración analógica de la -e (Karlsson 1981, 99-101). Sin embargo, Company Company $(2012,32)$ matiza la hipótesis de que -mente fue un préstamo y opina que se trataría de una reactivación a partir del intenso contacto cultural con dichas lenguas. Es una variante posible y ya existente en el castellano que se reactiva y refuerza. 
La variante justa mente es también la que aparece más tarde, en el siglo XV, en la gramática de Nebrija como ejemplo de un «adverbio de calidad»:

(15) otros muchos adverbios de calidad, por rodeo de algún nombre adjectivo \& este nombre miente o mente, que significa ánima o voluntad; \& assí, dezimos de buena miente, \& para mientes, \& vino se le mientes; \& de aquí dezimos muchos adverbios, como justa mente, sabia mente, necia mente; (Antonio de Nebrija, Gramática de la lengua castellana, 1492)

Otro argumento a favor de origen culto-escrito de justo es la ausencia de un adverbio corto paralelo a justamente ${ }_{1}$ 'con justicia'. Es decir, no existe un adverbio corto ?justo $_{1}$. El adverbio justo aparece exclusivamente con el significado justo ${ }_{2}$ 'exactamente' y justo ${ }_{3}$ 'apretadamente', que se documentan más tarde (siglo XV, véase apartado 3.1.3). A nuestro entender, el origen culto de justo ' 'según la justicia y el derecho' explica el hecho de que no se haya desarrollado su uso como adverbio, dado que los adverbios cortos son propios de la lengua popular (Hummel 2013a; 2013d; 2014a). En nuestra muestra base, no hay ningún registro de justo ${ }_{1}$ como adverbio. Sin embargo, la búsqueda específica de la combinación con determinados verbos en el CDH arroja unos pocos ejemplos. Los testimonios del uso adverbial de justo ${ }_{1}$ son muy escasos, además de tardíos (y posteriores a justo 2 'exacto' como adverbio):

(16) De tal manera que se restituya lo que se deve o se tomó, porque no haze al caso la intención con que se restituye el depósito, o se buelve lo prestado, o se paga lo devido si miramos sola la obra de justicia, aunque haze mucho al caso si queremos atribuyr la virtud de la justicia al que las obra, por lo qual esto es singular en las obras de la justicia que podemos obrar justo sin que tengamos la virtud de la justicia, y en las obras de las otras virtudes no podemos hazer las obras de las mismas virtudes sin que tengamos las mismas virtudes [...]. (Luis Saravia de la Calle, Instrución de mercaderes muy provechosa, 1544) ${ }^{11}$

(17) En esos pergaminos te presento

La desnuda verdad: está cumplida

Mi obligación. Desde hoy nuestra existencia,

Señor, está en tu mano.

Lee y lee sin pasión: juzga y sentencia:

Castiga justo, ó liberal perdona:

Tú eres el soberano:

Mas escoge entre el hijo y la corona. (José Zorrilla, Granada. Poema oriental, 1852)

(18) - - ...] Como hoy es viernes, puedo concederme un largo fin de semana. Para lo que me pagan...

-Has de abandonar ese empleo, si no pagan justo.

11 Las cursivas en los ejemplos citados son nuestras. Destacamos así el segmento modificado por el adverbio. 
$-Y$, encima, pretenden que trabaje y que trabaje cuidadosamente. (Juan García Hortelano,

El gran momento de Mary Tribune, 1972)

Como prueban estos ejemplos, no hay ningún impedimento sintáctico o semántico para usar justo ${ }_{1}$ 'según la justicia' como adverbio de modo de verbos como obrar, castigar o pagar. Por tanto, la casi ausencia de tal adverbio necesariamente se explica por otros factores, a saber: por preferencias diafásicas o diamésicas. Entre los autores consultados, Santos Río (2003) es el único en mencionar el uso de justo 'con justicia' como adverbio de modo: obrar justo. El autor tacha este uso de «raro». El hecho de que este adverbio corto no haya cuajado confirma, a nuestro modo de ver, la hipótesis del origen culto de justo 'según la justicia', ya que la lengua culta y/o escrita generalmente rechaza a los adverbios cortos (Hummel 2014a).

En cambio, derecho sí ha desarrollado y conservado el uso como adverbio corto (DLE 2014, s.v. derecho), tanto en español como en otras lenguas románicas. ${ }^{12}$ Se documenta ya en el Medievo, lo cual confirma de nuevo su origen patrimonial y su uso popular:

(19) Et dize assí, rrogando a Dios quel uista de uestimienta por quel ssea guardado el cuerpo de malas obras e quel çerque de justiçia por que ffaga bien e obre derecho en todo. (Alfonso $\mathrm{X}$, Setenario, 1252-1270)

\subsubsection{Cambio semántico: justo ${ }_{1}$ 'según la justicia' > justo ${ }_{2}$ 'exacto, preciso’}

De acuerdo con el estudio de Traugott $(1988,130)$ sobre el inglés just, el cambio semántico de 'según la justicia' a 'exacto' se originó en el contexto puente de las medidas. En el caso del español, efectivamente es este el contexto donde surgen usos ambiguos de justo a partir del siglo XIV. Concretamente, un primer contexto puente entre justo $_{1}$ 'correcto, según la justicia' y justo ${ }_{2}$ 'exacto' es el del peso justo de las monedas. Al parecer, este uso ya estaba presente en el latín IUSTUM PONDUS 'peso exacto’ (Segura Munguía 2013, s.v. IŪSTUs) y se prolonga en español:

(20) Sepan quantos esta carta vieren commo yo don Fernando [...] otorgo e conosco a vos los alcaldes e el alguazil e los caualleros e los ommes buenos del conçejo de la muy noble çibdad de Seuilla que por razón que vos yo rogué e vos mandé que entrásedes maneros

12 Como ya mencionamos anteriormente, el rumano drept se usa también como adverbio (Ciorănescu 2007). Asimismo, el uso adverbial del francés droit está plenamente documentado y supera a las documentaciones adverbiales de juste (Hummel/Gazdik en preparación), como comprobamos en la base de datos Adjective-Adverb Interfaces in Romance (Schneider et al. 2020). En la sección española de esta misma base de datos, el adverbio corto derecho también supera en número al adverbio corto justo. 
e debdores e pagadores por mi a Johán de Biualdo, cónsol de los genoeses de Seuilla, por él e por los otros genoeses de quien tomó el algo para mí Diego Garçi de Toledo, mío vasallo, ocho mill e nueueçientas e honze doblas e media de buen oro e de justo peso, las quales valíen en aquel tienpo a veynte e seys maravedís la dobla, que montaron en dineros dozientas e treynta e vn vez mill e seteçientos maravedís de la moneda blanca, que yo mandé labrar, que fazen diez dineros el maravedí [...]. (Anónimo, «Carta del rey don Fernando a Sevilla sobre la gestión de la harina por los alcaldes y el alguacil», 1310)

Las monedas se pesaban para determinar su valor exacto y correcto, con el fin de que todas fueran iguales en valor y peso. En este sentido, el peso es justo si se corresponde exactamente con las normas. Así, observamos nuevamente un solapamiento entre justo, derecho e igual:

(21) Por ende muy alto senor, notificamos lo ala vuestra alteza, ala qual muy omill mente suplicamos quele plega de rremediar en ello, mandando e defendiendo quelos tales engannos e falsedades non se cometan nin consientan nin pasen, penando alos que de tal guisa vsan delos tales pesos, e que de aqui adelante en todos los vuestros rregnos e sennorios sea vno e egual el peso dela dobla castellana e del florin de Aragon, e asi de todas las otras monedas de oro e plata de qual quier ley e cunno e que sea cada vna pesa de su moneda, en tal manera quela cantidad del peso de cada moneda sea justo peso derecho e egual, e non sea nin se vse en ninguna parte de vuestros rregnos mayor nin menor vno que otro, e el que lo contrario fiziere que por ese mesmo fecho aya e le sea dada pena de falso [...]. (Anónimo, Cuaderno de las Córtes celebradas en la villa de Madrid el año de 1435, 1435)

Además, encontramos una serie de ejemplos ambiguos de justo 'según la justicia' o 'exacto' en colocaciones con sustantivos como balanza y medida, es decir, en un marco relacionado con el justo peso:

(22) Por la tu mentirosa arte e muy fiel atrevimiento, revesas a mala parte al que tiene exalçamiento; pones en fonda baxura quien vive en buen estamiento, por do viene estroymiento quien das luenga soltura. Por ende, quien peso alcança tenga justa la balança. (Alfonso Álvarez De Villasandino, Poesías [Cancionero de Palacio], 1369-1440 [s. XV c1439])

(23) justiçia nunca fue fallesçida, aunque por nosotros non sea entendida; ca Tú judgas, Señor, por muy justa medida, al omne gualardón de muerte o de vida.

[...] 


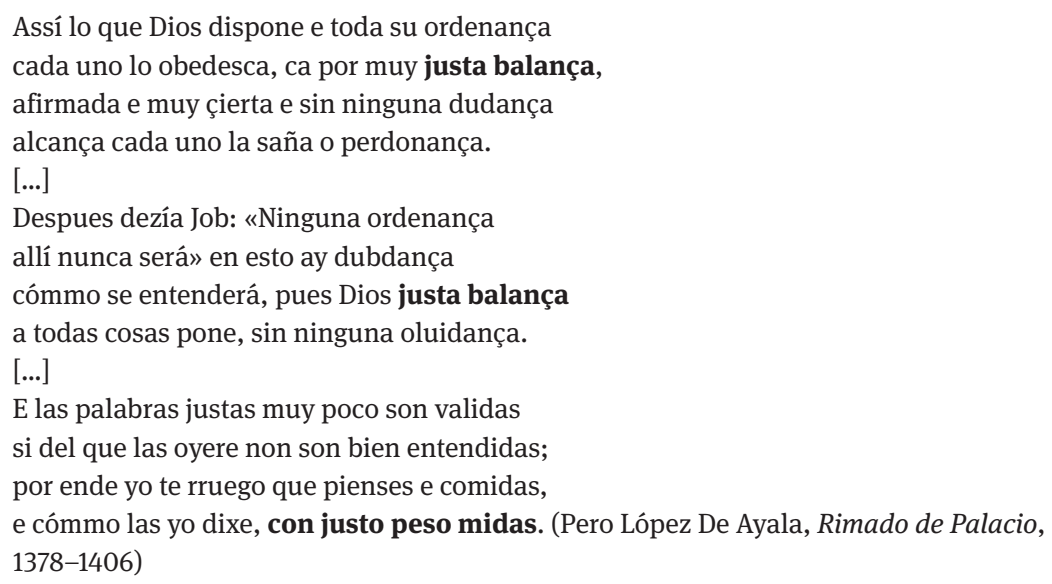

Una balanza exacta y precisa permite pesar las cosas de manera justa y equitativa, de ahí la ambigüedad de estos ejemplos. Según el DLE (2014, s.v. balanza), la balanza es un «aparato que sirve para pesar»; en este caso la interpretación de justo como 'exacto, preciso' sería la adecuada. Otra acepción, hoy desusada, es el uso metafórico de "comparación o juicio que el entendimiento hace de las cosas» (DLE 2014, s.v. balanza). En tal caso, justa balanza y juzgar con justa medida tienden más bien a la interpretación de justo ${ }_{1}$ 'según la justicia y la razón'.

La imagen de la balanza justa recuerda a la diosa romana de la justicia, Iustitia, que suele ser representada con una balanza en las manos para determinar exactamente el peso de los actos buenos y malos. Por tanto, la justicia y lo justo llevan a la idea de exactitud; la balanza justa y exacta es una representación metafórica de la justicia. Dicho de otro modo: la justicia -ya sea representada por la diosa romana Iustitia o por el Dios cristiano- necesita ser exacta y precisa para cumplir la premisa de ser justa y equitativa. La polisemia de justo nació, pues, de contextos ambiguos como balanza justa, justo peso y medida justa entre finales del siglo XIV y durante el $\mathrm{XV}$, aunque en parte retoma el uso ya latino de IUSTUM PONDUS 'peso justo'. Estos usos ambiguos unen matices de justo 'según la justicia' y justo ${ }_{2}$ 'exacto' y son, por lo tanto, los contextos puente de este cambio semántico.

Nótese que el uso de la justa balanza aparece primero en la poesía culta (véanse ejemplos 22 y 23) y luego parece extenderse a otros géneros literarios:

(24) Para dar contentamiento a tu reposada voluntad, quando te vieres atribulado, y de lo que pides a los dioses y a los hombres despedido, deves medir con derecha vara y pesar con iusta balança lo mucho que te han dado y lo poco que no te han conçedido. ¡O!, quán ingratos somos a los dioses y desconoscidos a los hombres, que el reçibo desminuimos con olvido y lo que se niega engrandesçemos con quexas. (Fray Antonio de Guevara, Libro áureo de Marco Aurelio, 1528) 
En suma, justo 2 'exacto’ nace de un ámbito concreto, el del peso exacto, adecuado y debido (IUSTUM PONDUS), y luego se traspone a otro más abstracto y metafórico. Además, aumentan los contextos de uso de la justa balanza, que pasa a referirse a cualquier tipo de equilibrio en cualquier situación comunicativa:

(25) do ui yo luego syn mucha tardança, en grand diuisión, duennas, donsellas, las unas muy feas, las otras muy bellas, queriendo romper la iusta ualança. (Carvajal, «Sin título», [Cancionero de Estúñiga], 1407-1463)

\subsubsection{Justo $/$ /justamente ${ }_{2}$ 'matemáticamente exacto'}

El componente semántico de exactitud se desliga de justo 'según la justicia' y acaba por dar lugar a una nueva acepción independiente: justo 'exacto' y justamente $_{2}$ 'exactamente' se empiezan a usar en contextos de medidas, cuentas, líneas matemáticas y números en general, sin el rasgo de justicia implícito. Hay, pues, una transición de una noción subjetiva de la exactitud a otra noción más objetiva; de un uso metafórico a un uso concreto.

Para documentar la diacronía de este uso, lanzamos varias búsquedas de diversas combinaciones léxicas en el $\mathrm{CDH} .{ }^{13}$ Alonso (1958, s.v. justamente, justo) data en el siglo XVIII la aparición tanto del adjetivo justo 'exacto, que no tiene en número, peso o medida ni más ni menos que lo que debe tener' como de justamente 'cabalmente, ni más ni menos'. Sin embargo, como muestran los ejemplos encontrados en el $\mathrm{CDH}$, este significado es bastante más temprano: ya aparece esporádicamente en el siglo XV y se consolida en el XVI. Por un lado, encontramos a mediados del siglo XV el uso de medida justa en el que el significado 'exacto' entra en primer plano, mientras que el rasgo semántico de justicia parece haberse perdido. Es decir, se trata de una exactitud objetiva, matemática:

(26) Allende de las cosas susodichas, deve ser el capitán prudente y discreto en muchas particulares cosas que contecen en las guerras, de las quales no se puede dar cierta doctrina.

13 Buscamos con el criterio más amplio posible para detectar también ejemplos en los que el adverbio no se encuentra contiguo al verbo: justamente/justo tanto a la derecha como a la izquierda de los lemas medir, calcular, pasar, dividir, señalar, cortar, tocar, con un intervalo máximo de 5 palabras. Además, buscamos la combinación con los lemas línea, cuenta, cálculo, cantidad, número, así como con la categoría numeral. La elección de estos lexemas y de los numerales se debe a su frecuencia en la muestra base. Así, pretendemos detectar las primeras atestiguaciones del significado 'exacto'/'exactamente', más allá de los ejemplos recogidos en la muestra base. 
Ca deve proveir de luengo tiempo en ellas y en las vituallas y mantenimientos, poniendo medidas justas y pesos ciertos, porque se vendan a peso y medida. (Rodrigo Sánchez de Arévalo, Suma de la política, 1454-1457 [segunda mitad del s. XV])

Por otro lado, en la colocación cuenta justa, el significado 'exacto' viene originariamente también vinculado al concepto de equilibrio: «cualquier cosa que esté igual con otra decimos estar justa, como cuenta justa, la que responde con igual cargo y descargo» (Covarrubias Orozco [1611] 1995, s.v. justo). En este sentido, la cuenta justa es la que no tiene ni demasiado ni poco y donde los ingresos se equilibran con los gastos. El primer ejemplo de esta combinación léxica, efectivamente, se refiere al balance exacto de las onzas:

(27) Yten, quel ofiçial que quisyere ser esamynado, en lo que toca al ofiçio del lienço, sea esamynado por los dichos veedores y sepa texer lienço y atavieras y echallos vyvos a las dichas atavieras y sepa texer manteles y faser en ellos tablas y totillos por arriba y por abaxo, y sepa contar y lizar un peyne mantelero, y asy mismo sepa tasar una sarta de fylado, quatro onças más o quatro onças menos, con que vaya en cuenta justa, y sy quysyere ser esamynado de todo y diere buena cuenta, que use de todo el oficio [...]. (Anónimo, «Nuevas ordenanzas de los tejedores de angosto de Cuenca», 1495)

También este segundo significado de justo se desarrolla de manera paralela al francés juste: hacia finales del siglo $\mathrm{XV}$, el adjetivo francés juste aparece como adjetivo de exactitud que se aplica a instrumentos y medidas exactas (DHLF 2000).

Al contrario de justo 'según la justicia', justo ${ }_{2}$ 'exacto' desarrolla un uso adverbial. El primer ejemplo del adverbio corto justo ${ }_{2}$ que hemos encontrado en el CDH es también de mediados del siglo XV, por lo cual ya es anterior a las fechas postuladas por Espinosa Elorza $(2014,1047)$, quien data el adverbio justo solo en el siglo XVII. En los ejemplos encontrados del siglo XV, justo funciona como adverbio de modo de los verbos cortar y medir. Su significado es meramente «matemático», no contiene ningún rastro de equilibrio o justicia:

(28) Capitulo .viijo. Del jnuentor dela sierra.(s)[S]ierra es vn jnstrumento de que mucho los carpenteros se ayudan para cortar qualquier madera mas justo \& mas ayna ${ }^{14}[. .$.

Capitulo .ijo. delos primeros ynuentores delos jnstrumentos de labrar \& coger \& medir pan [P]ues que el primero ombre non ovo conosçimjento delos jnstrumentos con que agora los labradores labran la tierra njn para coger pan njn para lo trillar \& aljmpiar \& avn medir justo es segunt nuestro proposito delo aquj declarar Onde el maestro dize que çeres en tiempo de esau enla terçera hedad jnuento los jnstrumentos de ljmpiar el pan \& medir el grano [...]. (Alfonso de Toledo, Invencionario. BNM 9219, 1453-1467)

14 Aína (adverbio): 'por poco', 'pronto', ‘fácilmente’ (DLE 2014, s.v. aína). En este ejemplo, tendemos a esta interpretación: cortar la madera más justo ‘exacto’ y más aína 'fácilmente’. 
Por otro lado, el segundo ejemplo encontrado de justo (adverbio) une el valor semántico de exactitud matemática con el matiz ‘equilibrado, moderado’:

(29) No ay cosa en el mundo do se requiera tan gran tiento como quando se mide el tiempo; porque el tiempo se ha de medir tan justo, que ni le falte a la razón tiempo para fazer bien, ni le sobre a la sensualidad tiempo para hazer mal. (Fray Antonio de Guevara, Reloj de príncipes, 1529-1531)

En cambio, justamente 2 'exactamente' aparece algo más tarde, en el siglo XVI, y también se da en el contexto de números, medidas y cálculos:

(30) Capítulo quarto de la prueva por nueves del partir, en que demuestra, quando las dos figuras que están encima y debaxo de la cruz son multiplicadas una por otra, vienen los nueves cabales o justamente, y, quando en la partición no sobra nada, cómo se a de asentar la prueva.

[...] aparta toda aquella suma de tres en tres letras, poniendo una raya en medio, escomençando por las figuras de azia man derecha. $Y$ veniendo poniendo las rayas azia man izquierda no oviere justamente tres letras sino una letra o dos letras, no te pene nada, porque aunque en aquella orden no vengan tres letras, bien podrás sacar d'ella tu raíz,

[...] Y en la mesma manera, multiplicando los quatro quintos, son 16 veinte y cincoabos. Pues ayunta 9 con 16 y serán 25. Pártelos por 25, que es la multiplicación de los 5, y viene uno justamente, como lo veis figurado.

[...] Si quisieres saber, o te fuere demandado, que quál será aquel nombre que quitándole dos tercios, quede justamente un ochabo, farás ansí.

[...] si por caso de la de quien yvas a sacar los nueves no sobró nada, sino que vino la partición justa, estonzes tanbién pondrás zero en el dicho brazo derecho. (Juan de Ortega, Composición del arte de la aritmética y geometría, 1512)

(31) De la primera dize: «quando tomardes el altura del sol en noventa grados», es a saber que el mediclini o medidor del mundo señala en vuestro astrolabio justamente los noventa, quando assí fuere «sabed que el sol es encima de vuestra cabeça».

[...] Quando quisiéredes saber, en qualquier año que estuvierdes, quántos son de áureo número sin mirar el libro, mirad en qué año corréys y, dexados los mil y quinientos, de los demás sacad los diez y nueves y lo que quedare, tanto es el áureo número esse año. Y si el número de los años viniere justo en diez y nueve, diez y nueve son de áureo número esse año. (Pedro de Medina, Arte de navegar, 1545)

(32) en el presente capítulo, del modo de saber medir justamente la ancheza de qualquier río se trata, la qual operación más propriamente toca al ingeniero que a otra persona alguna del campo y que, por ser ella mal entendida, muchas vezes se han perdido empresas [...]. (Luis Collado, Plática manual de artillería, 1592)

El Tesoro de la lengua castellana o española ya recoge el significado ‘algunas veces significa lo que está cabal en peso o medida’ (Covarrubias Orozco [1611] 1995, s.v. justo). En este sentido, es frecuente la combinación de justo ${ }_{2}$ y justamente con la $_{2}$ 
familia léxica medir/medida (véanse ejemplos citados arriba) y otros contextos «matemáticos», como números. Este uso se da también en el adjetivo justo:

(33) Pues sabe que con la mesma abiertura de compás con que se escriviere, con esa mesma ha de ser medida seys vezes justas su circumferencia. Por lo qual, le aconsejo que antes que se ponga a hazer figura que importe, preceda esta diligencia como fácil y necessaria. (Juan Alfonso de Molina Cano, Descubrimientos geométricos, 1598)

Además, tanto justo ${ }_{2}$ 'exacto, preciso' como justamente 2 'exactamente' expresan frecuentemente exactitud en el tiempo, por ejemplo, en referencia al número exacto de meses o de años. Alonso (1958, s.v. justamente) data el significado 'con que se expresa la identidad de lugar o tiempo en el que sucede una cosa' en el siglo XVIII, pero encontramos ejemplos de este significado en el adjetivo justo ya el siglo XVII. Citamos las primeras ocurrencias que encontramos de este uso de justo $_{2}$ (adjetivo y adverbio) y justamente : $^{2}$

(34) A los nueve meses justos

saldrá un niño como un sol, y no como otros, que nada fuera de los nueve son. (Jerónimo Cáncer y Velasco, «En las bodas del duque de Alburquerque...», 1645)

(35) Pero yo pregunto más; porque quatrocientos años justos, y ni uno menos, y uno mas. (Francisco Garau, El sabio instruido de la Gracia, 1703)

(36) [...] hállome con la obligación de hacer lo mismo hasta este año de 1705, en que justamente se cuentan 160 años desde su descubrimiento [...]. (Bartolomé Arzans de Orsúa y Vera, Historia de la villa imperial de Potosí, 1702-1736)

Como se observa en los ejemplos citados en este apartado, el significado «objetivo» de justo ${ }_{2}$ 'exacto’ y justamente 2 'exactamente' aparece preferentemente en textos en prosa, tales como textos políticos, historiográficos y, sobre todo, tratados científicos. Son propios, pues, de un estilo más bien descriptivo y llano, frente al elaborado discurso religioso y jurídico-moralista de justo ${ }_{1}$ 'con justicia'. En este sentido, cabe interpretar una difusión diafásica de justo y justamente: se extienden del registro escrito culto a un registro menos elaborado. ${ }^{15}$ Acaban por

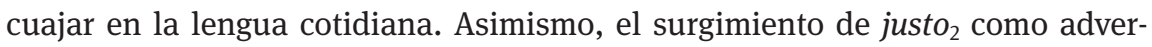
bio corto, a nuestro modo de ver, refleja el paso de esta voz a la lengua hablada y popular.

15 Sobre el lenguaje de los textos científicos del siglo XVI y su estilo «medio», entre culto y vulgar, véase nuestro análisis de al justo (Gerhalter 2020, 40-42). 


\subsubsection{Justo /justamente $_{2}$ 'exacto, adecuado, ni más ni menos de lo debido'}

Aparte del uso meramente objetivo-matemático de justo ${ }_{2}$ 'exacto' y justamente ${ }_{2}$ 'exactamente', hay continuidad de la idea de la balanza justa como equilibrio, ya que justo ${ }_{2}$ mantiene el matiz semántico subjetivo-valorativo de 'adecuado, moderado, ni más ni menos de lo que debe tener':

(37) el hombre que hubiere de hacer una buena ensalada ha de ser justo, liberal y miserable: justo en el vinagre, liberal en el aceite y miserable en la sal [...]. (Anónimo, La vida y hechos de Estebanillo González, 1646)

Las proporciones exactas y adecuadas corresponden a un ideal estético que rechaza proporciones desequilibradas o desiguales y exageraciones exuberantes:

(38) persuádome a que el santo no atendería tanto aquella parte de la hermosura que consiste en la justa medida y proporción de facciones y miembros, sino la otra que resulta al rostro de las buenas disposiciones [...]. (Miguel Fernández Munilla, fragmento, 1732)

(39) Por donde se echa de ver los excesos en que puede caer el poeta que sigue ciegamente los caprichos de su fantasía, sin discernimiento y sin juicio, y sin atender a la debida y justa proporción de las cosas. (Ignacio de Luzán, La Poética o reglas de la poesía en general y de sus principales especies, 1737-1754)

La idea de lo justo como perfecto equilibrio ya estaba presente en latín: IUSTA FORMA 'hermosura perfecta' (Segura Munguía 2013, s.v. IŪSTUS) y se corresponde con el ideal estético clásico. Según el DHLF (2000, s.v. juste), el matiz semántico 'equilibrado, conveniente' aparece también en la expresión francesa juste-milieu ‘justo medio', que hace referencia al concepto político de un punto de vista moderado. Este matiz data de finales del siglo XVI y se consolida en el francés del siglo XVII. De nuevo, se observa, pues, un desarrollo paralelo en francés y en español. El matiz semántico de justo ${ }_{2}$ 'apropiado, no demasiado, moderado, equilibrado' es también la base de la locución más de lo justo 'demasiado', 'más de lo justificable':

(40) No le plazen los costumbrados manjares, no las casas de onestas costumbres, no los manjares de poco precio, porque en las pobres casas pocas vezes entra esta enfermedad, mas escoje las cosas delicadas, porque Venus la onesta mora en las pequeñas casas e el mediano o pequeño pueblo tiene los desseos sanos e se ata con lo poco; por el contrario los ricos e fiantes en el real poderío codician más de lo justo: el que mucho puede, quiere poder de fecho lo que no puede de derecho. (El Tostado [Alonso Fernández de Madrigal], Sobre los dioses de los gentiles, 1507) 
(41) Sabido es lo que los santos refieren del evangelista San Juan [...]. De donde tomó ocasión Santo Tomás de Aquino en su Secunda Secunde al propósito. Y de San Pablo y San Antonio [...] se sabe que [...]. Otros muchos pudiera traeros a cuento, con que se alargaría éste mucho más de lo justo. (Francisco de Luque Fajardo, Fiel desengaño contra la ociosidad y los juegos, 1603)

(42) Fue tan desgraciada esta postrer salida que, alargándose más de lo justo, fueron cautivos de repente por un pirata corsario, que andaba encubierto haciendo algunas presas. (Mariana de Carvajal y Saavedra, Navidades de Madrid y noches entretenidas, 1663)

Se retoma un uso ya existente en latín: PLUS IUSTo 'más de lo justo' o LONGIOR IUSTo 'más largo de lo debido' (Segura Munguía 2013, s.v. IŪSTUS). Asimismo, Stettner $(1781,6)$ observa que, en el latín clásico, IŪSTUS implicaba un cierto equilibrio de las cosas que evita los extremos. En este sentido, la idea de justo ‘equilibrado, moderado' reprocha, en un principio, tanto el exceso como la insuficiencia:

(43) Ni un instante más ni menos de lo justo; ni una plumada siquiera en asuntos de la jurisdicción de otra mesa. (José María de Pereda, Tipos y paisajes, 1871)

Ahora bien, el matiz 'ni más ni menos de lo necesario o de lo que debe tener', 'moderado, equilibrado' se aplica frecuentemente en el sentido de 'no exagerado, no demasiado', es decir, reprochando principalmente el exceso y la exageración. Corresponde, pues, al topos ${ }^{16}<$ cuanto menos, mejor> (Santos Domínguez 1998). En este sentido, lo justo se convierte en lo absolutamente necesario, alude a la exacta cantidad mínima que todavía permite cumplir un propósito. Este matiz ('lo absolutamente necesario, lo mínimo posible') aparece principalmente con cantidades medibles:

(44) No se relacionaba apenas con nadie. Con la clientela no cruzaba más que las palabras justas, las que requerían los servicios de la profesión de que vivía. (Ángel Samblancat, $M i$ dama y mi «star», 1932)

16 Para una definición de este concepto, véase Anscombre/Ducrot (1994): los topoi son principios argumentativos que garantizan el encadenamiento argumentativo desde un argumento hacia una conclusión. Se trata de creencias comunes, compartidas al menos por los interlocutores del intercambio y, en general, por toda la comunidad lingüística. Se trata de principios generales que son válidos en varias situaciones. Además, los topoi son graduales: ponen en relación dos predicados graduales o dos escalas argumentativas y la relación entre ellas es gradual. 
(45) Ante las miradas risueñas de todos saludó con la espada y se prestó a que algunos congresistas le fotografiaran junto a su pequeño automóvil. No se había cambiado de traje, explicaron, porque solo disponía del tiempo justo para llegar a la ópera y cantar el Don Juan. (José Luis Sampedro, Congreso en Estocolmo, 1952)

En este último ejemplo, justo ${ }_{2}$ se refiere al mínimo tiempo necesario para llevar a cabo una acción: 'exactamente en el último momento'. Este uso también aparece con frecuencia en el adverbio corto justo ${ }_{2}$ :

(46) Zero oyó unos pasos tras de él y supuso que era Amador que volvía de telefonear; muy a tiempo, llegaba justo para las presentaciones. (Fernando Savater, Caronte aguarda, 1981)

(47) Cecilia se acercó a la playita, a las barcas allí aparcadas, eligió una y después de meterla en el agua saltó sobre ella. Remó en la dirección indicada por Valentina. Si se daba prisa llegaría justo a la puesta del sol, podría enviar su mensaje. Al advertir la increíble velocidad que en último momento había emprendido la redonda roja intentó acelerar el ritmo. (Emma Cohen, Muerte Dulce, 1993)

Mientras que este uso es habitual en justo ${ }_{2}$, no lo detectamos en justamente ${ }_{2}$. Por el contrario, otros usos de justo ${ }_{2}$ 'exactamente la cantidad mínima necesaria' corresponden al topos <cuanto más, mejor> y, por lo tanto, justo adopta el matiz de 'casi insuficiente':

(48) Existen cantantes con voces pequeñas y frágiles. Esos cantantes existen, sin duda, y su existencia refuerza mi convencimiento de que con inteligencia, buen gusto y amoldándose a sus posibilidades, dichos cantantes hacen carreras vocales muy dignas. Por el contrario, los cantantes que tienen volumen en la voz, pero andan justos de inteligencia y sensibilidad, que son los principales atributos del don vocal, se pierden antes de intuirse como profesionales. (ABC Cultural, 14/06/1996)

(49) El viejo Brull, que por avaricia y por prudencia tenía a su hijo a media ración -como él decía-, solo le enviaba el dinero justo para vivir; pero víctima a su vez de aquellas malas artes con las que en otro tiempo explotaba a los labriegos, había de hacer frecuentes viajes a Valencia, buscando arreglo con ciertos usureros que hacían préstamos [...]. (Vicente Blasco Ibáñez, Entre naranjos, 1900)

También en francés, juste desarrolla el matiz 'apenas suficiente', que radica en la idea de 'lo exactamente suficiente' (DHLF 2000). En suma, justo ${ }_{2}$ adapta una riqueza de valores y matices asociados, que retoman o reactivan en parte usos ya presentes en latín, que surgen del juego con los matices semánticos 'justo, adecuado, equilibrado' y 'exacto en cuanto a cantidades' en escalas graduales. Como estos matices se desarrollan también en francés, sería posible un préstamo semántico (esto es, calcos semánticos) del francés. 


\subsubsection{Justo $_{3} /$ justamente 3 'apretado, ajustado'}

A primera vista, este tercer significado parece encajar o surgir del segundo significado, ya que hace referencia a la medida exacta de algo. Más concretamente, aparece siempre en relación con la dimensión de un objeto tangible, que tiene las medidas mínimas exactas para su fin. Justo $_{3}$ 'apretado, ajustado' y justamente 3 se refieren a la dimensión perfecta de algo - ni demasiado grande ni demasiado pequeño-o al tamaño mínimo necesario, con lo cual comparten matices semánticos con justo $_{2}$ y justamente . $_{\text {. }}$

Sin embargo, el origen etimológico de justo ${ }_{3}$ 'ajustado' es más complejo, ya que no solo se relaciona con IŪSTUS - como indican la mayoría de los lexicógrafos - sino que deriva de una confusión con la preposición latina IUXTA 'junto a, cerca de', que expresa el límite de un movimiento. En este sentido, justo $_{3}$ 'ajustado' no se desarrolla de manera autónoma a partir de los cambios semánticos que venimos describiendo para justo ('según la justicia' > 'equilibrado' > 'matemáticamente exacto' > 'exacto en lo mínimo' > 'ajustado'), sino que se trata de una "colisión homonímica» entre IŪSTUS y IUXTA (García Sánchez 2006, 759-760).

Según de Miguel ([1867] 2000, s.v. IUXTA), la preposición latina IUXTA deriva de JUNXTA, de JUNGo 'juntar' y aparece, por ejemplo, en JuXTA Focum 'al lado del hogar', JUXTA VIAM 'junto al camino' o JUXTA MURUM 'cerca de la muralla'. Cuando se usa sin marca de caso, la preposición toma carácter adverbial: LEGIO QUAE JUXTA CONSTITERAT (Caesar) 'la legión situada más cerca de allí'. Como muestran estos ejemplos, el significado de IUXTA es claramente espacial.

De acuerdo con García Sánchez (2006, 758-760), la preposición IUXTA se prolonga como iusta hasta el castellano arcaico y así, la proximidad semántica y formal entre los resultados de IUXTA y IŪSTUS en español favorece su homonimia. Asimismo, el verbo ajustar viene de *AD-JUXTARE. Es decir, la preposición iusta se pierde en castellano y solo pervive en ajustar y ajustado, ${ }^{17}$ a la vez que justo $_{3}$ 'apretado' se asocia a los demás significados de las palabras derivadas de IŪSTUS.

Alonso (1958, s.v. justo) data en el siglo XVI la aparición de justo 'apretado, o que ajusta bien con otra cosa', lo cual coincide con los ejemplos de nuestra muestra sacada del CDH. Asimismo, el adjetivo francés juste desarrolla este uso de 'apretado, que encaja bien' en el siglo XVI (DHLF 2000). De nuevo, observamos un desarrollo paralelo entre el español y el francés.

17 Además, IUXTA reaparece en neologismos como yuxtaponer o yuxtaposición. 
Las primeras ocurrencias son todas del mismo autor y de su obra sobre agricultura. Justo ${ }_{3}$ 'ajustado' se aplica a cosas que «envuelven o contienen a otras o que se introducen dentro de otra o entre otras» (Moliner 1998, s.v. justo). Estas caben, entran o encajan exactamente, sin sobrar ni faltar espacio:

(50) y de tal manera adelgazen la pua que no toquen en la yema que entra enel enxerto. metan la sin premia/ y por la parte de fuera vayan tan justas las cortezas de la pua y del tronco: que quasi no se parezca. y aviendo puesto de cada cabo vna pua desta manera saquen la cuña/ por que apriete an le luego de atar muy bien: y poner le alguna cosa que defienda que ni el humor de dentro salga/ ni el agua si llouiere entre dentro.

[...] y la manera del adelgazar sea rayendo la igual mente de todo cabo: y metanla como quede justa ansi en hondo como en ancho, no tiene mas de adelgazarse de quanto lleguen alo blanco. (Gabriel Alonso de Herrera, Obra de agricultura, 1513)

Efectivamente, en esta acepción espacial se observa un cruce entre los significados 'exactamente la medida mínima' (< justo ${ }_{2}$ 'exacto') y 'junto a, cerca de' (< IUXTA). Los respectivos adverbios (justo ${ }_{3}$ y justamente j $_{3}$ ) aparecen también en el siglo XVI y se usan en relación con objetos que encajan o entran perfectamente dentro de otros sin que sobre ni falte espacio. Son, pues, contextos técnicos y matemáticos:

(51) donde se corta con el axe, de allí començarás a mover el compás, descendiendo y señalando hazia fuera hasta topar con la otra parte baxa del axe; e, si bien has medido, ha de venir justo con él, sin sobrar ni faltar d'él ninguna cosa. (Diego de Sagredo, Medidas del romano, 1526)

(52) metiósele una piedra de un cirial o roquedo en que topó, e pasó la nao adelante, e quedó la piedra muy fija e atestada en las tablas; pero no tan justamente inserta que entre ella e las tablas, en algunas partes no quedase abierto por aquellos lugares que la piedra no ajustaba con la tabla o madera, e por allí entraba tanta agua, que anegó el navío hasta que quedó asentado [...]. (Gonzalo Fernández de Oviedo, Historia general y natural de las Indias, 1535-1557)

(53) [...] tendido el hombre, los pies juntos y los braços assí abiertos, se haze quadrado de quatro líneas yguales: que la una le passa por la coronilla justamente y la otra por las plantas de los pies [...]. (Pedro Mejía, Silva de varia lección, 1540-1550)

(54) Después haz un fiel, que es un clavo del mismo latón, que por la parte del alhidada tenga una cabeça llana y redonda, y él sea muy redondo y entre justo en el agujero de la alhidada y astrolabio y a la punta tenga un agujero prolongado adonde quepa una chaveta que apriete el halhidada con el astrolabio, de manera que el alidada pueda andar alrededor del astrolabio [...]. (Martín Cortés Albacar, Breve compendio de la esfera y de la arte de navegar, 1551) 
(55) [...] lo qual se hará fácilmente sabiendo la medida de la grosseza de la pieza en la parte de atrás, la qual se tomará con un compás o con un hilo. De esta consideración nace la razón total del tirar justamente o no, mientras fuere justa la pieça, y justamente encaxada en su caxa y ruedas. (Cristóbal Lechuga, Discurso en que trata de la artillería con un tratado de fortificación, 1611)

Además, justo $_{3}$ y justamente ${ }_{3}$ aparecen frecuentemente en relación con ropa ajustada:

(56) Vestireys a vuestro gusto, si en vestir justo consiste, [...] El mismo os viste que a Dios, por ser el mas acertado, y aunque al justo os le ha cortado, os vendra muy ancho a vos. (Alonso de Ledesma, Conceptos espirituales, primera parte, 1600-1612)

Asimismo, el Tesoro de la lengua castellana o española, que data de principios del siglo XVII, cita este ejemplo para justo:

Vestido justo, el que viene amoldado. Justo como jubón de azotes, porque tal jubón listado vino tan justo que se pegó a las carnes. (Covarrubias Orozco [1611] 1995, s.v. justo)

En la muestra base, las ocurrencias de justo y justamente $_{3}$ son muy escasas y se limitan básicamente a los siglos XVI y XVII. Desde entonces parece que cayeron en desuso, mientras que otros lexemas resultantes de la colisión homonímica entre IŪSTUS y IUXTA se mantienen: ajustar, ajustado y ajustadamente.

\subsubsection{El variado inventario de adverbios basados en justo}

Dada la complejidad del inventario de los adverbios con la base léxica justo, contrastaremos en las siguientes secciones las alternativas al adverbio justamente, a saber: justo (adverbio corto invariable y flexionado) y al justo (locución adverbial, adverbio perifrástico o frase preposicional). Desde el punto de vista semántico, justamente es más polisémico que justo y al justo, ya que estos últimos solo aparecen con el significado (2) ‘exacto’ y (3) ‘apretado', mientras que justamente también se usa con el significado (1) 'con justicia'. Queda por analizar la diacronía de este grupo de adverbios. Sobre todo, hace falta un estudio más exhaustivo del adverbio corto justo y de la locución al justo, ya que estos se documentan solo marginalmente en nuestra muestra base. 
Desde el punto de vista cronológico, el adverbio justamente es anterior al adverbio corto, dado que el valor semántico de justicia se documenta ya en el

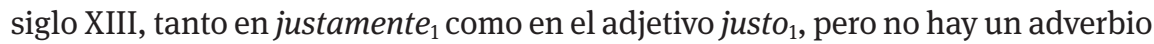
justo $_{1}$. Es decir, justamente es el único adverbio de justicia y su origen es culto, frente al adverbio popular derecham(i)ent(r)e, tal y como mostramos anteriormente (véase el apartado 3.1.2.2). Frente a justamente como adverbio culto, consideramos que el adverbio corto justo (con el significado 'exacto' y 'apretado') es propio de la lengua hablada. En este sentido, las documentaciones de justo en el $\mathrm{CDH}$ reflejarían la oralidad en los textos escritos.

En cuanto al significado 'exactamente', el uso del adverbio corto justo ${ }_{2}$ parece

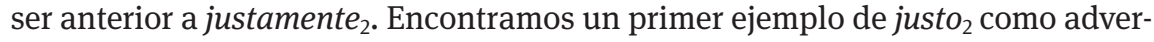
bio en la segunda mitad del siglo XV en construcciones como cortar más justo y medir justo (véase ejemplo 29, sección 3.1.4) y un segundo ejemplo de medir justo (véase ejemplo 30) en la primera mitad del XVI. En cambio, justamente ${ }_{2}$ 'exactamente' aparece a inicios del siglo XVI. Por lo tanto, justo es el primer adverbio de exactitud de este grupo léxico y justamente es una formación posterior, una adaptación a las reglas morfológicas de derivación adverbial en la lengua culta escrita. Esto parece indicar que la innovación semántica que da lugar al adjetivo justo $_{2}$ 'exacto' o bien surge en la lengua popular o bien se acepta rápidamente en todos los registros.

En nuestra muestra base de justo, el adverbio corto justo es poco frecuente: solo recogimos tres ejemplos del uso adverbial en los siglos XVI y XVII y solo reaparece con mayor frecuencia en el siglo XX. Se trata, por lo tanto, de un uso marginal. La búsqueda específica en el CDH arroja más ejemplos y muestra que el adverbio justo ${ }_{2,3}$ aparece a mediados del XV y se usaba, sobre todo, en el siglo XVI y, algo menos, en el XVII. Aparte de ejemplos como los citados en los que justo funciona como adverbio de modo de los verbos medir o cortar, también aparece como modificador de sintagmas en el siglo XVI:

(57) Quando el sol declinare de la equinocial hazia el un polo y las sombras nos fueren hazia el otro, juntaremos la declinación con el altura meridiana y, si todo no llegare a noventa, el complemento para los noventa estaremos apartados de la equinocial hazia aquel polo para el qual fuere la sombra. Y si pasaren de noventa, los que fueren más de noventa estaremos apartados de la equinocial hazia el polo que el sol declinare. Y si fueren justo noventa, estaremos debaxo de la equinoccial. (Martín Cortés Albacar, Breve compendio de la esfera y de la arte de navegar, 1551)

(58) el infelice y triste casamiento en forma y acto público se hizo.

Hoy hace justo un mes, joh suerte dura, qué cerca está del bien la desventura! (Alonso de Ercilla, La Araucana, segunda parte, 1578) 
Durante los siglos XVIII y XIX, justo (adverbio) parece caer casi en desuso. En la muestra base no se documenta ningún ejemplo y la búsqueda específica en el $\mathrm{CDH}$ arrojó solamente algunos pocos ejemplos del siglo XIX, pero ninguno del siglo XVIII:

(59) RITA Líbreme el Señor, amén, de estarlo nunca con nadie... y mucho menos con él. Voy a ver si me confieso, porque hoy somos veintitrés, y hace justo siete días que estuve la última vez. (Enrique Gaspar, La chismosa: comedia en tres actos y en verso, 1868)

(60) Como debe venir justo el número que marquen los dados, sumado con el que tiene el jugador, para quedarse en la casilla 63 y ganar la partida, siempre que el número de aquellos exceda de este, deberán retrocedérse tantas casillas [...]. (Carlos de Pravia, Manual de juegos, 1859)

Los siglos XVII y XVIII son particularmente puristas frente a los siglos anteriores y posteriores. En general, el siglo XVII fue una época de control lingüístico normativo que favorecía los adverbios en -mente y rechazaba los adverbios cortos que antes se usaban con más libertad (Hummel 2014a, 649). Probablemente por eso, el adverbio corto justo se marginaliza y desaparece de la escritura del siglo XVIII. Sería, pues, una variante más coloquial con escasa representación en el corpus escrito histórico frente al canónico justamente. Como la muestra diacrónica obviamente no cuenta con ejemplos orales ni tampoco se hizo una distinción de registros, no hay datos para confirmar que el adverbio justo es más habitual en la lengua informal-hablada y justamente en la lengua formal, culta y escrita (Hummel 2012, 158). Sin embargo, la baja frecuencia del adverbio justo en la muestra base parece indicar que tardó más tiempo en ser aceptado en la escritura que el adverbio culto justamente, que desplazó a justo durante los siglos XVIII y XIX.$^{18} \mathrm{El}$ adverbio corto justo no fue acep-

18 La preferencia por justamente se observa incluso en autores que reproducen el coloquio y la oralidad de su época: en los textos reunidos en el CORDE, Ramón de la Cruz (siglo XVIII) usa justamente, pero nunca justo, mientras que de Pérez Galdós (siglo XIX) solo hay un ejemplo de justo adverbial, frente a varios de justamente con el significado 'exactamente'. Esto podría indicar que justamente era más frecuente que el adverbio corto justo incluso en la lengua hablada de estos siglos. Agradezco esta observación a un revisor anónimo de mi artículo sobre al justo (Gerhalter 2020). 
tado plenamente en la lengua escrita hasta el siglo XX, cuando reaparece en la muestra base y experimenta un notable aumento: en los textos de la primera década del XXI, el 50\% de los casos de justo (todas las clases de palabras) en nuestra muestra base corresponde al uso como adverbio de exactitud (véase más adelante, apartado 3.1.8).

La escasez del adverbio justo en los textos históricos escritos complica su datación, como muestran las discrepancias entre las fechas proporcionadas por Espinosa Elorza (2014, 1047), quien data la aparición de justo (adverbio) en el siglo XVII. Asimismo, el DHLF (2000, s.v. juste) fecha la aparición del adverbio corto francés juste 'exactamente' en el siglo XVII. Alonso (1958, s.v. justo), a su vez, solo constata la aparición del adverbio corto justo en el siglo XIX. Sin embargo, como ha mostrado la criba exhaustiva en el $\mathrm{CDH}$, ya a mediados del siglo XV se encuentran documentaciones de justo como adverbio corto y estas se prolongan durante el XVI y XVII.

A pesar de la escasa documentación de este adverbio corto, los ejemplos del siglo XVI en los que justo aparece como modificador de sintagmas nos llevan a postular que la evolución de la polifuncionalidad adverbial de justo es paralela a la de justamente. Esto concuerda con el panorama general de los adverbios cortos y sus correspondientes adverbios en -mente (Hummel 2014a, 690-691). Más adelante (apartado 4.4.2 y capítulo 5), analizaremos la polifuncionalidad de justamente y justo con el fin de comprobar si el adverbio en -mente es más polifuncional y puede ocupar más funciones sintácticas que el correspondiente adverbio corto.

\subsubsection{Justo como adverbio corto flexionado}

Como criterio definitorio de la clase de palabras «adverbio» suele postularse su invariabilidad. Sin embargo, algunos adverbios cortos presentan a veces flexión. Es un fenómeno panrománico que corresponde típicamente a la tradición oral y subestándar y que se ve marginalizado por el proceso de estandarización (Hummel 2015). En varias lenguas romances, la flexión de adjetivos adverbiales en función de adverbios de modo no es aleatoria, sino que muestra correlación semántica en número y género con algún elemento nominal de la oración (Ledgeway 2017; Silvestri 2017).

La flexión de los adverbios cortos no se limita a los adverbios de modo, sino que también se da en adverbios modificadores de otras categorías (Hummel 2017, 34-39). Encontramos varios casos de flexión adverbial en justo como adverbio de exactitud que incide sobre sintagmas nominales. En varias ocurrencias de los siglos XVI y XVII, el adverbio corto justo concuerda con el sustantivo del sintagma nominal, pero su función es claramente adverbial, ya que introduce sintagmas 
nominales encabezados por un numeral y podría sustituirse por el correspondiente adverbio en -mente (justamente):

(61) Aquí descubrieron los pilotos sus puntos de sus cartas: el de la carabela Niña se hallaba de Canarias 440 leguas, el de la Pinta 420, el de la nao capitana, donde iba Cristóbal Colón, justas cuatrocientas. (Fray Bartolomé de las Casas, Historia de las Indias, 1527-1561)

(62) E assí paresce que no puede aver más que estas tres maneras, que son más de noventa, o menos de noventa o justos noventa. La primera está declarada. De la segunda dize esta regla que, quando el altura del Sol y su declinación ambos números juntos no llegaren a noventa grados, los que menos de noventa fueren está el hombre apartado de la línea a la parte que fueren las sombras. (Pedro de Medina, Regimiento de navegación, 1556)

(63) Lo mesmo concede Herodoto de alto y ancha, en la muralla, y de circuitu también, porque sus cuatrocientos y ochenta estadios hacen justos los sesenta mil pasos de Plinio, porque cada estadio es medida de ciento y veinte y cinco pasos; (Juan de Pineda, Diálogos familiares de la agricultura cristiana, 1589)

(64) Leyéronlo y decía ser de don Juan Osorio. Contáronlo y hallaron justos los tres mil escudos con los diez de a diez que yo decía. (Mateo Alemán, Segunda parte de la vida de Guzmán de Alfarache. Atalaya de la vida humana, 1604)

(65) y no hallando al Príncipe, fuimos cuatro jornadas lejos a la ciudad de Fogaraix, castillo y fortaleza fortísimo y de real habitación, adonde pasaba los inviernos por comodidad. Llegamos, siendo justos dos meses que nos partimos de Venecia; reposamos todo el día y a las dos horas dio audiencia a los Padres jesuitas. (Diego Duque de Estrada, Comentarios del desengañado de sí mismo. Vida del mismo autor, 1607-1645)

(66) Jueves que se contaron siete de Setiembre, año de mil treçientos y doçe según Mariana y según Illescas de treçientos y diez, aviendo acabado de comer y entrándose a reposar le hallaron muerto, justos treynta días después de la muerte de los Caravajales, a los quales mandó despeñar de la peña de Martos por indiçios que ubo sin bastante información de aver muerto un cavallero de la casa de los Benavides. (Sebastián de Covarrubias, Suplemento al Tesoro de la lengua española castellana, 1611)

\section{Este uso se mantiene marginalmente en siglo XVIII:}

(67) En caso que una línea excediesse a otra solo en una partícula; de modo que una línea tuviesse justos cinco millones de partículas indivisibles, y la otra cinco millones de partículas y una partícula más, una partícula indivisible sería la medida común. (Benito Jerónimo Feijoo, Cartas eruditas y curiosas, 1760)

En este tipo de ejemplos, la frontera entre adverbio y adjetivo es especialmente borrosa. ¿Son simplemente adjetivos antepuestos? Creemos que, al anteponerse a todo el sintagma e incluso al determinante (justos los sesenta mil pasos de Plinio), la función de justo tiene que ser adverbial, pero muestra un paralelismo claro con el correspondiente adjetivo: los sesenta mil pasos justos de Plinio. 
En los casos citados, la flexión del adverbio refleja una cohesión lógica con el segmento al que modifica: el adverbio concuerda en número y género con el sustantivo que forma el núcleo del sintagma nominal al que focaliza, al igual que el numeral presenta concordancia. No se trata, pues, de un uso arbitrario, sino que esta flexión está claramente motivada por una coherencia semántica y morfosintáctica.

La flexión del adverbio generalmente refleja un uso oral popular (Hummel 2014a, 673-674). En este sentido, los usos flexionados podrían confirmar, de nuevo, que justo ‘exacto' se usaba ya en el siglo XVI en el lenguaje oral popular. De acuerdo con nuestras búsquedas en el CDH, los casos de flexión parecen ser incluso más frecuentes que los casos no flexionados del adverbio corto durante los siglos XVI y XVII. Además, los ejemplos citados reafirman que, en el siglo XVI, justo ya funcionaba como adverbio modificador de sintagmas.

Según Hummel (2015, 208-209; 2017, 36-37), justo es un modificador del grupo de los determinantes con funciones consideradas adverbiales (focalizadores y especificadores), al igual que el adverbio solo, que también presenta flexión: solos tres y solos hombres. En general, el fenómeno de los adverbios «intuitivamente» flexionados es antiguo: predomina en el Medievo y se va perdiendo en Europa por cuestiones de purismo lingüístico, mientras que se mantiene en el español americano (Hummel 2015, 222; Hummel 2017, 37). Efectivamente, comprobamos que el factor diatópico es relevante, ya que los ejemplos de justo como adverbio flexionado en el siglo XX son americanos:

(68) Se puso el cabo del arreador debajo de las asentaderas y empezó a contar. Al llegar a ciento le hacía un nudo a la sotera y empezaba de nuevo. Luego sumó los nudos. Salieron justos mil quinientos terneros. (Carlos Reyles, El gaucho Florido. La novela de la estancia cimarrona y del gaucho crudo, 1932)

\subsubsection{La locución adverbial con preposición al justo}

El adverbio perifrástico al justo integra la preposición $a$, el artículo el y el adjetivo justo, y se usa con los significados (2) 'exactamente' y (3) 'apretadamente':

1. loc. adv. Ajustadamente, con la debida proporción.

2. loc. adv. Cabalmente, a punto fijo. (DLE 2014, s.v. justo/al justo)

Nuestra muestra base contiene 10 ocurrencias de la locución adverbial al justo, todas ellas de los siglos XVI y XVII. Así que, en nuestra muestra base de justo, la locución adverbial es incluso más frecuente que el adverbio corto justo durante estos siglos. La búsqueda específica de la combinación al justo en el CDH 
confirma que esta locución carece del valor semántico de justicia y que se usaba, sobre todo, durante los siglos XVI y XVII. ${ }^{19}$ Igual que el adverbio corto justo ${ }_{2}$, la locución al justo 2 'exactamente' aparece en el contexto de medidas y del tiempo, como adverbio de modo y como modificador de sintagmas:

(69) Traté en mi mocedad, por fatal orden, una fregona de hermosos ojos, un mezclado color de grana y nieve y de un cabello de madejas de oro, un mes al justo; porque en este tiempo me puso de propósito los cuernos. (Baltasar del Alcázar, Obra poética, 1550-1606)

(70) Y aunque esta cuenta que he dicho es la más precisa que se sabe para saber al justo el punto de la marca los navegantes usamos otra más vulgar y de menos dificultad [...] debe comenzar la cuenta desde veinticinco de abril, porque estando entonces las guardas en la cabeza, es al justo medianoche y al mismo respecto se debe ir haciendo en todo el discurso del año [...]. Todos los cuales números de leguas vienen a ser, al justo, dos mil ochenta leguas, que he dicho que había desde la entrada de el estrecho de Magallanes al mismo puerto de Cartagena. (Juan Escalante de Mendoza, Itinerario de navegación de los mares y tierras occidentales, 1575)

(71) Ha sucedido en la isla Tercera, que á los 12 del pasado, último de Pascua, vino un grande temblor y terremoto, el cual se continuó por algunos dias, en los cuales se cayeron mil seiscientas casas, veinte y nueve iglesias y monasterios, y murieron 600 personas en los lugares de la Isla, aunque no se podia saber el número al justo, por estar enterrados debajo de las paredes caidas los muertos [...]. (Luis Cabrera de Córdoba, Relación de las cosas sucedidas en la corte de España desde 1599 hasta 1614, 1599-1614)

(72) Cortó de una hoja de un libro viejo las letras muy al justo y, dividiéndolas por sus repartimientos, como hazen en la imprenta, las fue después pegando sobre otro papel con alquitira y escribiendo con ellas lo que se sigue: (Juan Mendez Nieto, Discursos medicinales, 1606-1611)

Tanto en las fechas de uso como en la semántica, la locución al justo coincide con el adverbio corto justo. Es decir, al justo tampoco aparece con el significado primario ‘con justicia'. Esto apoya la teoría de Hummel (2019; 2014a, 697-705)

19 No cuantificamos el número de ocurrencias de la locución adverbial al justo en el CDH, ya que hay demasiadas ocurrencias en las que justo ${ }_{1}$ funciona como sustantivo (castigar al justo...) o usos que no corresponden a la perífrasis adverbial (llegar al justo medio...) como para repasarlos manualmente. Para un recuento cuantitativo de al justo en el CORDE y un análisis pormenorizado de al justo y de al cabal, remitimos a una publicación aparte, en la que defendemos que se trata de locuciones elaboradas durante el proceso de Sprachausbau y que al justo, efectivamente, era más frecuente que el adverbio corto justo y justamente entre mediados del siglo XVI y mediados del siglo XVII (Gerhalter 2020). 
de que las expresiones perifrásticas podrían tener un origen en común con los adverbios cortos. Como muestra el siguiente ejemplo, al justo parece usarse como alternativa al adverbio corto justo:

(73) Vestireys a vuestro gusto, si en vestir justo consiste, porque el oficial que os viste jamas vistio sino al justo. El mismo os viste que a Dios, por ser el mas acertado, y aunque al justo os le ha cortado, os vendra muy ancho a vos. (Alonso de Ledesma, Conceptos espirituales, primera parte, 1600-1612)

En resumen, al justo se crea en el siglo XVI como variante del adverbio corto justo y al principio parece usarse incluso con más frecuencia que este. Al parecer, la locución al justo era la variante más aceptada de las dos en los textos del corpus, pero cae en desuso cuando el adverbio derivado justamente se impone a las demás variantes en el siglo XVIII. Al contrario del adverbio corto justo, la locución adverbial al justo no reaparece en la escritura del siglo XX.

Llama la atención que en francés se crea una locución adverbial según el mismo esquema: au juste ‘al justo'. El DHLF (2000) no data con precisión la aparición de esta locución adverbial («avant 1787»), pero una consulta en la base de datos Frantext confirma que esta locución se usa ya a finales del siglo XV y en contextos paralelos al español al justo:

Cestui mesura justement les corps celestes par les regles de geometrie, et trouva moult au juste la haulteur de Saturne et des autres planetes et signes, (Simon de Phares, Recueil des plus celebres astrologues, 1494, Frantext)

Al contrario del español al justo, la locución francesa au juste se ha mantenido y se sigue usando en la actualidad: Que s'est-il passé au juste? (Larousse, en línea).

Asimismo, ao justo se usa desde el siglo XVIII en portugués:

Raimundo Alves, o herdeiro esbanjador de bonita fortuna, e que nem sabia ao justo quantos filhos naturais tinha em vários lugares. (Lindolfo Rocha, Maria Dusá, siglo XVIII, Corpus do português, Davies/Ferreira 2006)

\subsubsection{El paradigma morfológico adverbial}

El inventario de los adverbios de exactitud provenientes de la familia léxica de justo es diverso: contamos con un adverbio derivado en -mente, un adverbio corto 
que se usa de forma invariable y flexionada y, por último, una locución adverbial. Consiguientemente, hablaremos de un paradigma morfológico: variantes morfológicas de una misma raíz léxica (justo) y una misma función sintáctica (adverbio). Como hemos analizado en los apartados precedentes, el primer integrante de este paradigma es el adverbio corto justo invariable (mediados del XV), seguido a principios del siglo XVI por el uso flexionado de este adverbio corto, el adverbio derivado justamente 2 y la locución al justo.

Así pues, el paradigma morfológico de los adverbios de exactitud que pueden ocupar una misma función sintáctica, como, por ejemplo, la de modificadores de sintagmas, presenta variación durante el siglo XVI. En este contexto de uso se documentan todas las variantes:

(i) adverbio derivado

Y veniendo poniendo las rayas azia man izquierda no oviere justamente tres letras sino una letra o dos letras [...]. (Juan de Ortega, Composición del arte de la aritmética y geometría, 1512) (véase ejemplo 30)

(ii) adverbio corto flexionado

el de la carabela Niña se hallaba de Canarias 440 leguas, el de la Pinta 420, el de la nao capitana, donde iba Cristóbal Colón, justas cuatrocientas. (Fray Bartolomé de las Casas, Historia de las Indias, 1527-1561) (véase ejemplo 61)

(iii) adverbio corto invariable

Y si pasaren de noventa, los que fueren más de noventa estaremos apartados de la equinocial hazia el polo que el sol declinare. Y si fueren justo noventa, estaremos debaxo de la equinoccial. (Martín Cortés Albacar, Breve compendio de la esfera y de la arte de navegar, 1551) (véase ejemplo 57)

(iv) locución adverbial

Todos los cuales números de leguas vienen a ser, al justo, dos mil ochenta leguas, que he dicho que había desde la entrada de el estrecho de Magallanes al mismo puerto de Cartagena. (Juan de Escalante de Mendoza, Itinerario de navegación de los mares y tierras occidentales, 1575) (véase ejemplo 70)

Además, el contexto semántico de la precisión de un número exacto también aparece en el adjetivo base de estos adverbios:

Pues sabe que con la mesma abiertura de compás con que se escriviere, con esa mesma ha de ser medida seys vezes justas su circumferencia. (Juan Alfonso de Molina Cano, Descubrimientos geométricos, 1598) (véase ejemplo 33)

${\text { Además, } \text { justo }_{3} \text { 'apretado’ y justo }}_{2}$ 'exacto’ aparecen frecuentemente en una colocación con el verbo venir (64 casos en el CDH). Por tanto, siguen la tendencia de los adverbios adjetivales a formar construcciones lexicalizadas con un verbo 
determinado (Kovacci 1999, 713; Company Company 2017, 263). En estos ejemplos, es frecuente la flexión:

(74) y cubran le con vna cobertura de barro tanto grande que venga justa ala boca del barreño o con otro tal barreño y estas coberteras esten pegadas por dentro y fuera [...]. (Gabriel Alonso de Herrera, Obra de agricultura, 1513)

(75) de allí començarás a mover el compás, descendiendo y señalando hazia fuera hasta topar con la otra parte baxa del axe; e, si bien has medido, ha de venir justo con él, sin sobrar ni faltar d'él ninguna cosa. (Diego de Sagredo, Medidas del romano, 1526)

(76) setecientos y veinte y uno: y tantos huevos daréis que podía llevar esta mujer. Los cuales si se cuentan de dos en dos, sobrará uno: y de tres en tres sobrará otro, etcétera. Y si se cuentan de siete en siete, vienen justos. (Juan Pérez de Moya, Diálogos de aritmética práctica y especulativa, 1562)

En estos casos, la clasificación de justo como adjetivo o adverbio es ambigua. Si lo interpretamos como adjetivo predicativo, estaríamos ante un verbo pseudocopulativo y oraciones semipredicativas. En cambio, si lo interpretamos como adverbio flexionado, justo modifica el verbo venir y muestra concordancia de número y género con el sustantivo del sujeto (respectivamente: cobertura justa, compás justo, huevos justos). Un argumento a favor de una posible interpretación adverbial de la colocación con venir es el hecho de que este verbo se combina también -aunque con menor frecuencia- con los adverbios justamente y al justo:

(77) Después, d'estos 72 tercios faze dos tales partes que la una se pueda partir por 5 y la otra por 8, en manera que vengan justamente. (Juan de Ortega, Composición del arte de la aritmética y geometría, 1512)

(78) Porque muy acaso suelen venir al justo las cuentas ordinarias de la una que se saben de memoria, y casi todas ellas vienen a parar en poco más o menos por la irregularidad de su movimiento. (Juan de Escalante de Mendoza, Itinerario de navegación de los mares y tierras occidentales, 1575)

A nuestro modo de ver, ambas interfaces entre usos adjetivales y usos adverbiales -la precisión de números exactos y la colocación con el verbo venir- justifican la visión de Hummel (2014a; 2017), quien parte de una sola macrocategoría de atributos que pueden mostrar flexión o no; mientras que la creación de una categoría formalmente marcada para los adverbios (-mente) corresponde a esfuerzos del Sprachausbau en la lengua culta escrita. Además, teniendo en cuenta la existencia de adverbios flexionados, no se justifica que la flexión sea un criterio para separar la categoría de adjetivos de la de adverbios (Hummel 2015). 
En el caso concreto que acabamos de ilustrar, la variación dentro del paradigma morfológico, propia de los siglos XVI y XVII, se va perdiendo: mientras que justamente es el único adverbio que se documenta ininterrumpidamente en el $\mathrm{CDH}$, el adverbio corto justo (flexionado e invariable) y la locución al justo se marginalizan a partir del siglo XVIII. Es solo en el siglo XX cuando el empleo adverbial de justo invariable vuelve a aceptarse en la escritura. En cambio, el adverbio flexionado y la frase preposicional al justo solo se conservan marginalmente en algunas variedades diatópicas americanas.

\subsubsection{Sintesis: la diacronía de justo y justamente}

Desde las primeras documentaciones de justo y justamente en el siglo XIII, está presente el significado originario del latín, 'según la justicia', que aparece, sobre todo, en la variante contextual de 'según la ley de Dios' en el discurso religioso. A través del desvío por esta variante contextual religiosa, originaria del latín tardío cristiano, justo 'según la justicia' se retoma como cultismo en las lenguas romances. Hemos alegado varios argumentos a favor del origen culto de justo ${ }_{1}$ 'según la justicia': la preferencia por las voces populares y patrimoniales derechero, derecho y derecham(i)ent(r)e en los textos alfonsíes, la falta de variación formal en justamente ( ${ }^{\star}$ justam [i]ent [r]e) y la casi ausencia de un adverbio corto justo ${ }_{1}$ 'con justicia'.

Entre los siglos XIV y XV, el adjetivo justo experimenta un cambio semántico que da lugar al nuevo significado 'exacto, preciso'. El concepto de exactitud surge de la idea del equilibrio ('ni más ni menos de lo justo y de lo debido') y de la metáfora de la balanza justa. Por analogía, este segundo significado aparece también en los adverbios justo (mediados del XV) y justamente $_{2}$ (mediados del XVI), fundamentándose, pues, en el adjetivo subyacente. Además, la coincidencia homonímica con la preposición latina IUXTA 'junto a, cerca de' influye en el desarrollo del tercer significado: justo $_{3} /$ justamente $_{3}$ 'apretado, ajustado'.

La Tabla 6 resume la cronología de los distintos significados:

Tabla 6: Primeras atestiguaciones de justo (adjetivo, sustantivo, adverbio) y justamente en el CDH.

\begin{tabular}{llllll}
\hline & $\begin{array}{l}\text { justo } \\
\text { (adjetivo) }\end{array}$ & $\begin{array}{l}\text { justo } \\
\text { (sustantivo) }\end{array}$ & $\begin{array}{l}\text { justo } \\
\text { (adverbio) }\end{array}$ & $\begin{array}{l}\text { al justo } \\
\text { (adverbio) }\end{array}$ & $\begin{array}{l}\text { justamente } \\
\text { (adverbio) }\end{array}$ \\
\hline $\begin{array}{l}\text { Siglo XIII } \\
\text { Siglo XIV }\end{array}$ & justo $_{1}$ & justo $_{1}$ & & & justamente $_{1}$ \\
Siglo XV & justo $_{2}$ & & justo $_{2}$ & & \\
Siglo XVI & justo $_{3}$ & & justo $_{3}$ & al justo $_{2,3}$ & justamente $_{2,3}$ \\
\hline
\end{tabular}


En cuanto a la frecuencia de estos tres significados básicos de justo en nuestra muestra base (véase Gráfico 1), observamos varias tendencias: el valor semántico de justicia (en azul: justo ${ }_{1}$ adjetivo y sustantivo) predomina hasta el siglo XX. En los textos medievales, justo ${ }_{1}$ se usa predominantemente como sustantivo (es decir, en un contexto religioso), lo cual encaja con el origen religioso de este cultismo.

El segundo significado - el de exactitud (en naranja: justo ${ }_{2}$ como adjetivo y adverbio, incluyendo los casos de contexto puente) - va ganando terreno progresivamente. Finalmente, acaba por superar al primer significado en el período más reciente. En este gráfico, la categoría justo ${ }_{2}$ (adverbio) incluye todos los usos de justo: tanto los ejemplos de justo como adverbio corto (se documenta en los siglos XV-XVII y XX-XXI), como los ejemplos de la locución adverbial al justo (siglos XVI-XVII) y de justo como marcador de afirmación (siglo XX-XXI, véase capítulo 6). El llamativo aumento del segundo significado a partir del siglo XX se debe, sobre todo, al uso de $\mathrm{justo}_{2}$ como adverbio corto. En cambio, el tercer significado es muy marginal y por razones de legibilidad no hemos diferenciado entre uso adverbial y adjetival. Solo se documenta en nuestra muestra base de los siglos XVI y XVII.

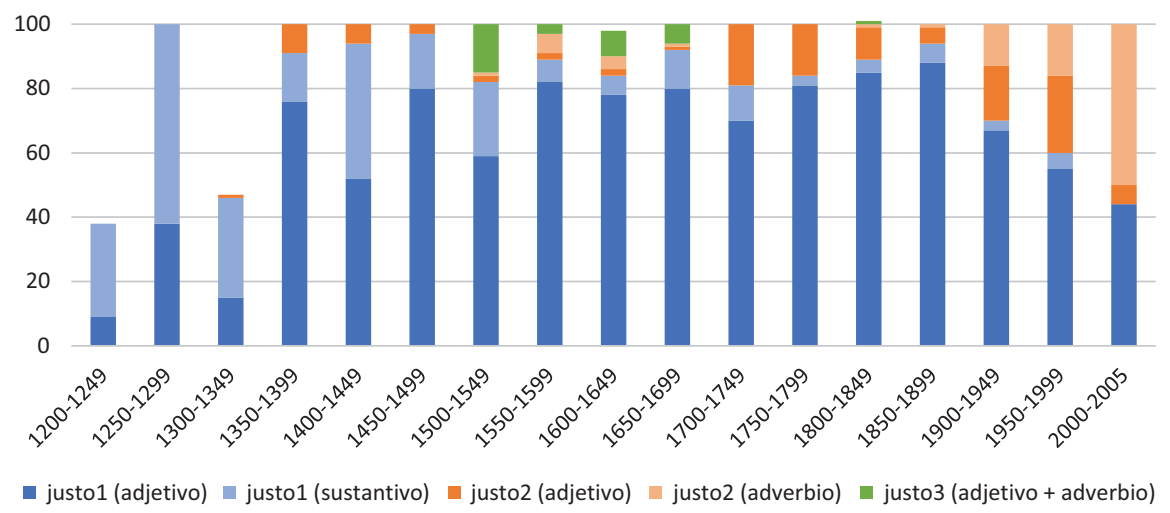

Gráfico 1: Dispersión diacrónica de los significados de justo en la muestra base (máx. 100 ocurrencias por medio siglo).

La expansión del segundo y tercer significado ('exacto', 'apretado') y la diversificación formal y funcional (adverbio flexionado, locución y marcador discursivo) reflejan la popularización o coloquialización de justo en los textos recogidos en el corpus: el uso originariamente culto de justo ${ }_{1}$ 'según la justicia (de Dios)' está siendo desplazado por nuevos usos que reflejan un arraigo de esta voz en la lengua hablada y en registros más populares. 
A continuación, el Gráfico 2 muestra que el adverbio justamente se emplea solo esporádicamente hasta mediados del siglo XIV, ya que durante la Edad Media se usaba como adverbio de justicia el adverbio derechamente con todas sus variantes de origen patrimonial (véase apartado 3.1.2.1).

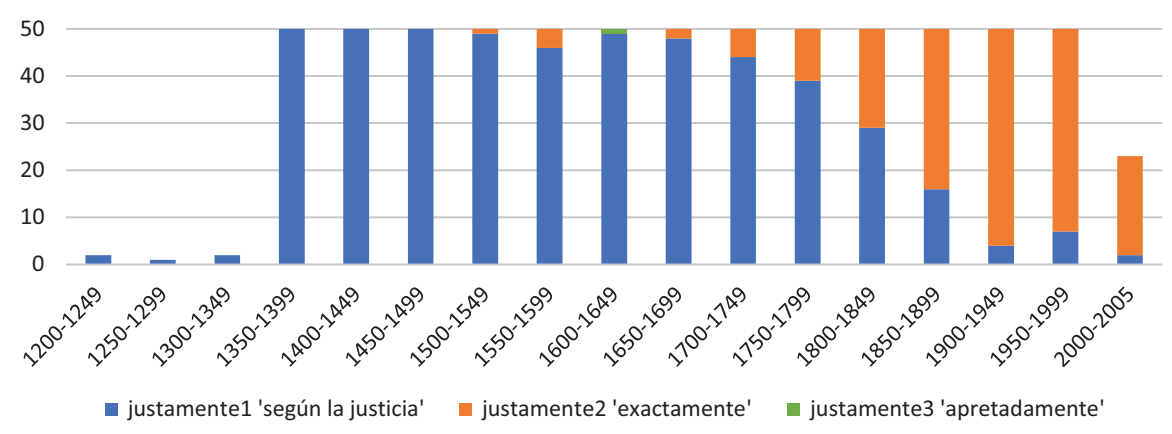

Gráfico 2: Dispersión diacrónica de los significados de justamente; número de ocurrencias en la muestra base de máx. 50 ocurrencias por medio siglo. ${ }^{20}$

En cuanto a las frecuencias de los significados de justamente, el Gráfico 2 muestra cambios paralelos a los de justo: el segundo significado va aumentando y acaba por superar al primer significado. Esta tendencia está más avanzada en el adverbio: justamente supera a justamente $_{1}$ ya a mediados del siglo XIX. Asimismo, el tercer significado, 'apretado', se usa escasamente durante los siglos XVI a XVIII y parece haber caído en desuso en el español moderno.

Por último, en el caso de justo y justamente, nos parece probable una influencia importante desde el francés juste/justement, ya que ambos comparten casi todos los usos y matices semánticos. Al principio, su desarrollo es paralelo: juste y justo provienen del discurso religioso y recuperan o retoman el uso jurídico en el siglo XIII. Hacia finales del siglo XV, aparecen en el contexto de instrumentos y medidas exactas. Sin embargo, mientras que el DHLF (2000, s.v. juste) sostiene que este uso del adjetivo francés juste hoy en día es anticuado, sí se ha mantenido en el español actual. En otros casos, el francés parece adelantarse al español: el adverbio francés justement desarrolla diversos usos y matices antes que el español justamente (Gómez-Jordana 2012).

20 En el siglo XXI, el CDH solo recoge 23 ejemplos de justamente. 


\subsection{Cabal y cabalmente}

En el español actual, se distinguen básicamente dos significados de cabal y cabalmente: por un lado, aparecen en el contexto de cantidades, medidas, unidades de tiempo y, por otro, aparecen en el contexto del comportamiento de personas. En el primer caso, cabal hace referencia a lo que 'cabe o corresponde a cada uno’ (véanse s.v. cabal: DHLE 1933-1936; Casares 2007; DLE 2014), como muestra también esta definición:

«Se añade como 'justo' a la expresión de la cantidad que corresponde en un reparto: Nos correspondieron mil pesetas cabales (mil a cada uno).» (Moliner 1998, s.v. cabal)

También significa ‘ajustado a peso o medida', ‘exacto’ (Casares 2007, s.v. cabal):

«Se aplica a lo que se expresa exactamente y no solo en aproximación: Aquí hay dos mil pesetas cabales. $=$ exacto.» $($ Moliner 1998, s.v. cabal $)$

Ese significado 'exacto’ enlaza con el de 'completo, entero':

«Exacto o completo en su medida, porque no sobra ni falta nada: Tuvo su segundo hijo a los dos años cabales del primero.» (CLAVE 1999, s.v. cabal)

«Sin faltar nada: En esta tienda damos el peso cabal = completo.» (Moliner 1998, s.v. cabal)

La idea de 'completo, entero' también aparece en las locuciones al cabo 'al fin, por último' y al cabo de 'después de' (DLE 2014, s.v. cabo), formadas sobre el mismo sustantivo base que cabal: cabo 'extremo, fin'. En este sentido, cuando cabal se atribuye a objetos contables (monedas, unidades de tiempo, etc.), hace referencia básicamente a un número completo. Se cumple el número entero de algo (los días del año, el precio de algo, etc.) cuando el número llega al final, al extremo. Al mismo tiempo, el número completo implica exactitud: dos años cabales significa que han pasado dos años completos, enteros y, simultáneamente, esa indicación del tiempo se puede tomar como exacta y precisa.

En segundo lugar, cabal se usa con el significado 'perfecto, excelente en su clase' (véanse s.v. cabal: DHLE 1933-1936; DLE 2014). Según Casares (2007, s.v. cabal), se trata de un uso figurado. Este significado aparece, sobre todo, en referencia a personas, donde adopta los matices 'honrado, trabajador y estimable en cualquier aspecto' (Moliner 1998, s.v. cabal):

«Que tiene juicio y honradez: Puedes fiarte de ella, porque es una chica cabal.» (CLAVE 1999, s.v. cabal) 
Este significado también aparece en la locución estar alguien en sus cabales 'tener normales sus facultades mentales' (CLAVE 1999, s.v. cabal):

«Estar cuerdo: Tú no estás en tus cabales... ¡Salir a cuerpo con este frío!» (Moliner 1998, s.v. cabal)

Además, existen las locuciones por sus cabales 'cabalmente o perfectamente, por su justo precio, por su orden' (Casares 2007) y por su cabal 'con mucho empeño, con mucho ahínco, poniendo todo de su parte' (DLE 2014, s.v. cabal), que igualmente remiten a este segundo uso de cabal, relacionado con el comportamiento moral de las personas.

En el caso del adverbio cabalmente, la información proporcionada por los diccionarios es escasa. El DLE (2014, s.v. cabalmente) solamente recoge la definición ‘de manera cabal' sin especificar a qué significado de cabal se refiere, mientras que el CLAVE y Moliner ni siquiera mencionan este adverbio. Según Egea $(1979,221)$, cabalmente significa, por un lado, 'precisa, justa y exactamente' y, por otro, 'completa y perfectamente'. Santos Río (2003) clasifica cabalmente como 'adverbio de medida o bien de aspecto' y cita un ejemplo del significado 'completamente, en su totalidad, del todo':

Para comprender cabalmente el alcance de esta máxima se necesita tiempo. (Santos Río 2003, s.v. cabalmente)

Según Santos Río (2003, s.v. cabalmente), este adverbio cuenta con restricciones (no solo de registro) que completamente no tiene. El autor parece referirse a la marginalización diafásica de cabalmente en el español actual, que se limita a un registro muy culto y elevado. ${ }^{21}$

Además, Kaul de Marlangeon (2002, 114-115) menciona el ejemplo cabalmente profesor, cuyo significado remite a 'perfectamente, con razón': la autora describe ese uso de cabalmente como adverbio que «cuantifica la manera en que se presenta la propiedad ser profesor; optimizándola o destacándola, dentro de la clase profesor». Por lo demás, no relaciona cabalmente con los adverbios de exactitud justamente, precisamente y exactamente (Kaul de Marlangeon 2002, 118-119).

21 Preguntamos a varios lingüistas nativos por este adverbio y nos confirmaron la marcación diafásica de cabalmente 'perfectamente, por completo, como tiene que ser' como un adverbio extremadamente raro y literario-culto. 
El Diccionario histórico de la lengua española (= DHLE) (1936) es el único en ampliar la definición de cabalmente a 'precisa, justa o perfectamente'. Proporciona una larga serie de ejemplos del siglo XIX que indican que este adverbio adquirió usos paralelos a precisamente y justamente:

En fin, ninguna te gusta. - No, que antes me gustan todas y por eso cabalmente no me caso. (Bretón, El pro y el contra, 1883, citado en el DHLE [1933-1936, s.v. cabalmente])

La mujer a que se ama es cabalmente la mujer a quien menos se le dice. (Santa Catalina, Obr., 1876, citado en el DHLE [1933-1936, s.v. cabalmente])

A raíz de estas entradas lexicográficas formulamos la siguiente hipótesis: cabalmente hoy en día apenas se usa como adverbio de exactitud, pero históricamente lo era. Por eso, para un estudio diacrónico del grupo de justamente, precisamente y exactamente, es relevante incluir también cabalmente. Al parecer, el adverbio cabalmente solo se ha conservado marginalmente como adverbio de modo con el significado 'completamente, como tiene que ser, perfectamente'.

Por último, la posible existencia de un adverbio corto cabal queda por verificarse en el corpus, ya que a pesar de que algunos diccionarios mencionan el uso de cabal como adverbio de modo con el significado 'cabalmente' (véanse s.v. cabal: Moliner 1998; DLE 2014), ninguno da ejemplos. Además, el DLE (2014, s.v. cabal) y el DHLE (1933-1936, s.v. cabal) también registran la locución adverbial al cabal ('cabalmente, al justo'), que el DLE clasifica como desusada y el DHLE como anticuada.

\subsubsection{El origen léxico: $c a b o>c a b a l$}

El adjetivo cabal es poco frecuente en el español de hoy en día, pero una serie de lexemas de su misma familia léxica sí se han conservado con más vitalidad. El adjetivo cabal deriva del sustantivo cabo, que a su vez viene del latín CAPUT (DLE 2014, s.v. cabo). En latín, CAPUT es altamente polisémico: 'cabeza, parte principal, origen, autor, causa, punto principal, lo primero, capitulo, sumario, compendio, el fin, el cabo, el extremo, la embocadura' (véanse s.v. CAPUT: de Miguel [1867] 2000; Blánquez 2012). De la acepción 'cabeza, punto principal' de CAPUT se deriva ya en latín el sustantivo CAPITĀLIS, que se presta al español y otros idiomas europeos como capital (Corominas/Pascual 1997, s.v. capital). También se formó ya en latín el diminutivo CAPITULUM 'cabecita' > 'letra capital que encabeza un capítulo', que se presta como capítulo al español (Corominas/Pascual 1997, s.v. capítulo).

En castellano, tanto capital como capítulo son cultismos, es decir, préstamos literarios, como revela la conservación del fonema oclusivo sordo intervocálico - $p$ - 
En cambio, CAPUT se convierte por vía hereditaria-patrimonial en cabo, a través del cambio fonético característico de la sonorización de los oclusivos sordos intervocálicos. ${ }^{22}$ Este mismo cambio se observa también en cabeza, que proviene del latín vulgar hispánico CAPITIA, que a su vez sustituyó al latín clásico cAPUT (Corominas/ Pascual 1997, s.v. cabeza).

Al formarse sobre el sustantivo patrimonial cabo, el adjetivo cabal es una formación nueva que no cuenta con antecedentes latinos. No se hereda ni por vía popular ni por vía culta, sino que se crea en algún momento de la historia del español mediante el sufijo - al, es decir, el mismo sufijo que ya en latín había creado, a partir de CAPUT, CAPITALIS (> esp. capital). El adjetivo cabal 'completo' está documentado en todas las lenguas romances de la península ibérica, a saber: portugués, gallego, asturiano, castellano, aragonés, catalán, valenciano y también provenzal (véanse s.v. cabal: DHLE 1933-1936; Alonso 1958; García de Diego 1985; Grup Enciclopèdia Catalana), pero no existe, por ejemplo, en francés o italiano. No consideramos probable que cada una de las lenguas iberorromances haya formado independientemente cabal por sufijación a partir de cabo. Como apunta Machado (1967, s.v. cabal) para el portugués, es preferible reconstruir o bien un origen común, de un posible adjetivo popular ${ }^{\star}$ CAPĀLE en el latín ibérico, o bien una exportación de esta voz desde uno de los romances ibéricos para los demás.

Las documentaciones de cabo ‘extremo' en castellano son antiguas: Corominas/Pascual (1997) ya fechan este sustantivo en el siglo X. Se usa especialmente en contextos temporales, como en la expresión cabo de año 'final del año' en esta documentación del siglo XI:

mulier que embibdare non faciat sernam fasta cabo de anno. (Fuero de Palenzuela (Col. El Moral), citado en Lapesa et al. 2003, s.v. cabo)

La locución preposicional al cabo de con significado temporal ('después de, al final de’) se remonta al latín. Según Campos (1972, 200), esta locución ya se usaba esporádicamente en latín clásico y llegó hasta el español por vía popular: «ad caput + genitivo, 'a cabo, a cabo de' (adv.), 'junto a' (prepos.): > ad capum > ad capo > 'a cabo de'». En el latín tardío, el uso de esta locución se extiende desde las versiones bíblicas; por ejemplo, está ampliamente documentada en la Vulgata y refleja «un uso del habla común y muy expresivo» (Campos 1972, 200). La

22 Dicha lenición probablemente ocurrió por influencia del sustrato celta en el latín vulgar de la parte occidental de la Romania (Lapesa 2008, 82), a partir de los últimos siglos del Imperio Romano (Penny 2016, 557-558). La sonorización de consonantes oclusivas sordas intervocálicas del castellano concluyó antes del siglo X (Núñez-Méndez 2016, 580). 
primera documentación de la expresión castellana es del siglo X y significa 'al cabo de quince días':

quod est in riiio de Ebeia, usque ad caput de XV dies, II dies et duas noctes [...]. (Cart. Catedr. Burgos 41, año 970, citado en Campos 1972, 200)

Es una expresión de uso extendido que se encuentra en varios documentos notariales, es decir, era habitual en el discurso administrativo. En ocasiones se escribe en latín, pero la construcción en sí ya es castellana. Ejemplos como el siguiente muestran, pues, una «construcción latina y casi castellana» (Campos 1972, 201):

leuetis totam uestram causam ad caput de $\mathrm{VIII}^{\circ}$ dies, que leuetis uestras portas et uestros uscios et illas kasas et illas bardas non desfaciatis que adte capo de anno. (Sahagún, 650 (Oríg.), año 1092, citado en Lapesa et al. 2003, s.v. cabo)

La búsqueda de la locución al cabo de o a cabo de en el CDH confirma que se usaba frecuentemente en la Edad Media para contar el paso de las unidades de tiempo:

(79) Cuando esto fecho ovo, a cabo de tres semanas,

de Castiella venido es Minaya,

dozientos con él, que todos ciñen espadas,

non son en cuenta, sabet, las peonadas. (Anónimo, Poema de Mio Cid, 1140 [s. XIV])

(80) E al cabo de los ochenta dias, desque fue partida la batalla, e se fueron los griegos para las tiendas e los troyanos para la villa [...]. (Anónimo, Historia troyana en prosa y verso, 1270)

Este significado de cabo ‘fin, extremo' también es el que subyace al verbo acabar literalmente 'hacer algo hasta el cabo'- que data del siglo XII (Corominas/Pascual 1997, s.v. cabo), y que también existe en portugués y catalán. Asimismo, la expresión llevar a cabo 'terminar, acabar, concluir algo' (Real Academia Española 2014, s.v. cabo) deriva de la idea de realizar algo hasta su final, hasta completarlo.

Al surgir de una expresión del latín tardío, la locución al cabo de es anterior al adjetivo derivado cabal. Corominas/Pascual (1997, s.v. cabo) datan la primera documentación de cabal 'completo, perfecto, porque llega hasta el final' en el siglo XII, concretamente, en el año $1155 .{ }^{23}$ En el CDH, cabal se documenta desde el siglo XIII. En los primeros ejemplos de cabal -que provienen igualmente del

23 Según Alonso (1958, s.v. cabal), cabal no aparece hasta el siglo XV, fecha que precisa de corrección. 
discurso administrativo- observamos ambigüedad entre 'entero, lleno, completo' y ‘por cabeza, cada uno' en el contexto de medidas:

(81) Los iugueros accipiant boues ad quinto, et dent unicuique II kafices ${ }^{24}$ cabales de pan, medio de trigo et medio de centeno, et media octaua de sal, et III pares d'auarcas bonas. Et qui magis dederit, aut magis pecierit, pectet IIII morabetis al castiello [...]. (Anónimo, Fuero de Cáceres, c1234-1275)

Dos cahices cabales equivale o bien a 'dos cahices enteros y llenos', o bien se quiere expresar que a cada persona le corresponden dos cahices. Asimismo, se documenta desde el siglo XIII el uso de cabal en las medidas del tiempo, es decir, con el mismo valor que la locución al cabo de. En estos ejemplos, la cuenta de días o años enteros, cumplidos, invita también a la interpretación de un valor de exactitud:

(82) Et asy commo cuenta paulo orosio en el.xvj. capitulo del seseno libro del dia que jullio çesar salio de la çibdat de rroma desta vez fue a diez \& siete dias cabales en syguença. (Alfonso X, General Estoria. Quinta parte, 1284 [s. XV])

(83) E despues que el fue muerto fue alçado por los godos el noble Rey banba \& Reyno este Rey Resusendo diez \& nueue años cabales \& murió en el año de/dclxxv \& ansi acabo el Rey Resurendo de los godos [...]. (Alfonso Martínez de Toledo, Atalaya corónicas, 1443-1454)

La idea de exactitud deriva, pues, de 'completo, entero' y surge en el dominio de las cuentas del tiempo. En este sentido, cabal se usa como equivalente a justo ${ }_{2}$, como muestran estas dos entradas lexicográficas del siglo XVII:

«tres años cabales: tres años enteros, completos, justos» (Oudin 1607, s.v. cabal).

«la cosa está cumplida, sin que le falte ni le sobre nada: el numero cabal, cuando está cumplido. [...] Dezimos estar la cosa justa y cabal, porque se ajusta con su medida y peso» (Covarrubias Orozco [1611] 1995, s.v. cabal).

Mientras que el uso de justo en el contexto de medidas exactas o en el contexto de las unidades de tiempo no surge hasta el siglo XV (véase apartado 3.1.3), este uso en cabal ya se documenta en el siglo XIII y en la locución al cabo de incluso ya en el latín vulgar. Como prueban las documentaciones en el $\mathrm{CDH}$, cabal es anterior a los demás adjetivos de exactitud (justo, preciso, exacto) y, efectivamente, es el primero del grupo en adquirir este uso. Queda, pues, afirmada nuestra hipótesis.

24 Cahiz: Medida de capacidad para cereales, diferente según las regiones. (DLE 2014, s.v. cahíz) 
En este punto, cabe mencionar que el adverbio latino de exactitud DĒMUM (Espinosa Elorza 2014, 1047) también se usaba en el contexto de contar las unidades del tiempo cumplido: ANNO DEMUM QUINTO 'al cabo de los cinco años' (Segura Munguía 2013, s.v. DEMUM). En este sentido, podemos concluir que cabal y al cabo de no solo son las primeras expresiones de exactitud en español, sino que probablemente sustituyeron directamente a los adverbios de exactitud latinos COMMODUM, COMMODĒ y DĒMUM.

En el siglo XV, observamos en varios ejemplos que justo se va sumando a cabal. Por ejemplo, en lo referente al precio:

(84) una, porque en esta vendida e otorgamiento que vos fago de los dichos bienes non ovo nin ha arte nin enganno alguno; e lo otro, porque los dichos bienes vos vendo por su justo, conbenible, caval preçio nonbrado de los dichos quinientos florines d'oro que yo de vos resçibí por los dichos bienes, commo dicho es. (Anónimo, «Escritura de venta», 1408, Colección diplomática del Concejo de Segura [Guipúzcoa])

Además, cabal se usa también para la cuenta de entidades no temporales (en este ejemplo, personas) y, por lo tanto, extiende su uso a contextos nuevos:

(85) luego por los indios que estaban a la mira fue aviso al lugar donde la junta estaba con la determinación dicha. Y aunque tuviesen este designio los naturales, en quien se hizo la liga para matar a los españoles o lanzarlos de sus tierras, todavía aunque no eran cabales sesenta, les temían extrañamente; y este temor caber en tantos y que estaban en su tierra y la sabían y conocían no sé a qué se puede echar sino a Dios todopoderoso [...]. (Pedro Cieza de León, Crónica del Perú, 1553)

Igual que en el caso de justo, es frecuente la combinación de cabal con el verbo venir a partir del siglo XVI. Aparece especialmente en contextos de números en la explicación de operaciones aritméticas, en las que cabal significa 'exacto, entero, completo':

(86) Y si la primera letra escomençare en siete, por quanto viene cabal siete, allí no curarás d'él, sino de la secunda letra, guardando todo lo sobredicho de la primera letra. [...] Pues ya véis que aquí vienen cabales los diezes, pon zero debaxo de la raya enfruente de las letras que son centenas, y si llevo 2, los quales ayunta a los zeros que están en lugar de millar. (Juan de Ortega, Composición del arte de la aritmética y geometría, 1512)

(87) después de algunos trances, juntamente con los cónsules Hircio y Pansa, contra Marco Antonio; porque, contando desde aquí y no de otra manera, viene cabal el nascimiento de Christo a los quarenta y dos años del imperio de Octaviano, como luego mostraré. (Pedro Mejía, Silva de varia lección, 1540-c1550) 
En otros contextos, cabal se acerca al valor de justo 'adecuado, perfecto, conveniente':

(88) PREGONERO: Padre, de cuanto gastáis

por cas de los pasteleros,

pues holgando lo ganáis,

¿será mucho que hagáis

la fiesta a tres compañeros?

BUÑOLERO: Acabá, sacá dineros.

Un real venía justo y cabal.

FRAILE: Toma, y dame mi bacina [...]. (Sebastián de Horozco, Entremés, 1550)

El segundo significado, el de cabal $_{2}$ 'perfecto, honrado' en cuanto al comportamiento de personas también se relaciona con el concepto de justo: «El hombre cabal, cuando es perfecto en virtudes y en guardar especialmente justicia» (Covarrubias Orozco [1611] 1995, s.v. cabal). Ese uso es posterior y se documenta en el CDH a partir del siglo XVI:

(89) «Cómo, Señor, por una cosa que tan poco importa como que venga aquel o no venga quiere Vuestra Magestad dexar de hazer la paz que por el presente tanto le importa, prinçipalmente viniendo un tan cabal hombre como éste, que pocos de tal suerte debe de tener el rrei de Ungría en su corte?» [...]. (Anónimo, Viaje de Turquía, 1557-1558)

(90) Vino por capitán Luis Lanchero, Varon cabal para cualquier afrenta, Después en este reino fué guerrero Que de sus cargos dió muy buena cuenta; (Juan de Castellanos, Elegías de varones ilustres de Indias, 1589)

\subsubsection{La diacronía de los adverbios cabalmente, cabal y al cabal}

En lo que atañe el adverbio cabalmente, no hemos encontrado ningún dato sobre su diacronía en los diccionarios consultados, con excepción de los ejemplos citados en el DHLE (1933-1936, s.v. cabalmente), que en ningún caso son anteriores al siglo XIX. La búsqueda del lema cabalmente no arroja ejemplos anteriores al siglo XVI, pero la búsqueda específica por variantes diptongadas como cabalmientre ${ }^{25}$ aclara

25 En el ejemplo citado, el CDH no lematiza cabalmientre como «cabalmente», sino como «desconocido». Por tanto, esta ocurrencia se encuentra mediante la búsqueda por formas. Como muestra este ejemplo, aunque el CDH esté lematizado, no hay que dejar de buscar también diversas variantes en la casilla de «forma», tal y como hicimos con cabalmente y justamente. 
que este adverbio sí se usaba ya en la Edad Media, concretamente, en el siglo XIII, cuando las variantes patrimoniales del sufijo -mente todavía estaban en uso:

(91) porque lo contedes, e fallaredes que viene siempre este sábado de sedmanas a cabo de siet sedmanas de años. E si alguno bien lo quisiere contar en siet sedmanas de años á VII VII años en la sedmana, como á en la sedmana siet días, fallará ý XLIX años cabalmientre, e el que viene adelant es el Lo año, e aquell año mandó Dios que fuesse el jubileo. (Alfonso X, General Estoria. Primera parte, 1275 [s. XIII c1270])

En el ejemplo citado, cabalmientre se refiere a la exactitud en el cálculo de los años según un tipo de calendario: 'fallará allí exactamente 49 años'. Se corresponde, pues, con el valor de exactitud que ya presentaba cabal en este mismo siglo en el discurso administrativo y técnico y, además, coaparece con la locución a cabo de. Mientras que a cabo de muestra el matiz 'completado, entero' ('después de siete semanas'), cabalmientre permite una interpretación como adverbio de exactitud: cabalmientre ${ }_{2}$ 'exactamente, ni más ni menos'.

Según Karlsson (1981, 89-92), la forma vernácula -mientre es la más antigua y todavía la más usada en la prosa de Alfonso X. En este sentido, la atestiguación de la forma diptongada -y a la vez la ausencia de la variante culta ?cabal mente y de la variante apocopada ?cabalment, de las cuales no hemos encontrado ni un registro- parecen indicar el arraigo popular de esta voz. Este hecho concuerda con la tradición patrimonial de la familia léxica cabo, cabal, al cabo de.

Esta misma documentación de cabalmientre aparece en el CORDE. De acuerdo con el Cordemáforo de Rodríguez Molina/Octavio de Toledo y Huerta (2017), la primera parte de la General Estoria en el CORDE es «fiable». Esto es, recibe la etiqueta verde, ya que la primera (y cuarta) parte de la General Estoria se han transmitido en testimonios originales de la cámara regia alfonsí (Rodríguez Molina/Octavio de Toledo y Huerta 2017, 26). Dado que este texto se ofrece en el CORDE a partir de una transcripción paleográfica del manuscrito original, es un texto que reúne las máximas garantías de fiabilidad filológica (Rodríguez Molina/Octavio de Toledo y Huerta 2017, 46). Consiguientemente, opinamos que la documentación alfonsí de cabalmientre es fiable y refleja o bien su uso real y difundido en la época, o bien una innovación particular que prueba la productividad y transparencia semántica de esta formación adverbial. Igual que en el caso de derechero (véase apartado 3.1.2.1), la prosa alfonsí se acerca más a la oralidad -es decir, a la lengua hablada real- de la época medieval que otras obras.

La documentación de cabalmente es muy escasa durante la Edad Media. No hemos encontrado más documentación aparte de la citada de cabalmientre. ${ }^{26}$

26 Buscamos en CDH, CORDE y Corpus del Español (Davies 2002). 
Tal y como apuntamos en el apartado anterior, la exactitud en datos y números se expresaba preferentemente mediante la expresión al cabo de y mediante el adjetivo cabal. Teniendo en cuenta el arraigo popular de esta familia léxica, recordamos que la tradición popular prefiere las formas cortas y las locuciones adverbiales (Hummel 2014a), frente a la tradición escrita culta de los adverbios en -mente (Company Company 2012a; 2014b). Esto podría explicar la escasez de cabalmente.

Es en el siglo XVI cuando cabalmente aparece de nuevo - y de manera paralela a justamente- en el contexto de contar unidades de tiempo, medidas y números:

(92) Porque haga algo de lo que quiere le envío ese silicio, para que traya dos días en la semana: entiéndese desde que se levanta hasta que se acuesta, y no duerma con él. En gracia me ha caído el contar de los días tan cabalmente. Uso nuevo es, y no creo han alcanzado esa habilidad las Descalzas. Mire que nunca se ponga esotro; ahora, estése guardado. (Santa Teresa de Jesús, «Carta a D. Lorenzo de Cepeda en Ávila. Toledo, 27 y 28 de febrero de 1577», 1577)

(93) Y para que la vandera quede en medio del esquadrón avráse d'este modo: si las hileras fueren en número impar, sin que sobre nada, pondrála en el medio de la hilera de en medio, como si me diessen 625 soldados, cuya raýz es 25 , que son los soldados que llevará por la frente el esquadrón, a quien hallará que le mide él cinco cavalmente; y porque es número impar, pondrá en el medio de la tercera hilera, que es la del medio del cinco, la vandera, yendo marchando, y assí, quedará en el medio del esquadrón. (Diego Álava de Viamont, El perfecto capitán, 1590)

Al mismo tiempo, cabalmente mantiene el significado 'enteramente, completamente':

(94) Para que sea propio basta que declare, de las cosas que son propias a aquella de quien se dice, alguna de ellas; mas si no las declara todas entera y cabalmente, no será igual. Y así a Dios, si nosotros le ponemos nombre, nunca le pondremos un nombre entero y que le iguale, como tampoco le podemos entender como quien Él es entera y perfectamente; (Fray Luis de León, De los nombres de Cristo, libros I-III, 1583)

También adquiere el significado paralelo a cabal $_{2}$ 'perfecto, honrado, justificado'. Es decir, cabalmente ${ }_{2}$ se usa con el significado 'perfectamente, adecuadamente' en referencia al comportamiento de personas:

(95) Nunca Homero imaginó que la propriedades que él puso en la cinta de Venus habían de hallar tal abono en la sancta Escritura; mas, como dice muy cabalmente Aristóteles, que toda verdad se lleva bien con toda verdad, ansí también se dice con razón que toda verdad 
viene de Dios y, habiendo hablado Homero doctrinal y verdaderamente, tuvo su lenguaje alguna semejanza con el divino. (Juan de Pineda, Diálogos familiares de la agricultura cristiana, 1589)

Durante los siglos XVIII y XIX, cabalmente $_{1}$ se usa con significados equivalentes a justamente, precisamente y exactamente (véase el capítulo 5 para el análisis pragmático de estos adverbios de focalización):

(96) A esta sazón llegó dicho sargento mayor Ogasson a caballo con la ronda y vino a pararse cabalmente adonde estaba aquella mujer con su marido de pie mirando y debía de tener buenas barbas, como dicen, y empezó a enamorarla y dicen llegó a ponerle la mano en los pechos, con que la mujer se encolerizó y arrimóse más de su marido, quien con algún brío debió de decir: Caballero, esa señora es mi mujer. (Raimundo de Lantery, Memorias, 1705)

(97) Pero el verdadero principio de las Matemáticas sólo puede tomarse de los griegos posteriores, cuando se vieron por éstos establecidos teoremas, fijados métodos para resolver problemas, y reducidas a principios generales y a leyes estables algunas particulares y vacilantes verdades. Y esto sucedió cabalmente cuando la Grecia se gloriaba de sus sabios y empezaba a ver elevar sus escuelas filosóficas. (Carlos Andrés, Traducción de Origen, progresos y estado actual de toda la literatura, de Juan Andrés, t. VII y VIII, 1793)

En el español actual, dicho uso de cabalmente se ha perdido. En los ejemplos que analizamos - tanto en el $\mathrm{CDH}$ nuclear como en la extensión sincrónica (1975-2005) -, solamente se documenta el uso de cabalmente 2 'perfectamente, completamente, adecuadamente, como tiene que ser'. Es un adverbio de modo, por ejemplo, de verbos como comprender, actuar o responder:

(98) Asimismo, habrá de lograrse un amplio conocimiento de los visitantes y sus expectativas, las cuales obviamente pueden llegar a ser muy altas después de que frecuentemente hacen gastos considerables para llegar a un área protegida remota. Hace falta comprender cabalmente el efecto que los visitantes tienen sobre los recursos naturales y culturales y sobre los demás visitantes. (Héctor Ceballos-Lascuráin, Ecoturismo. Naturaleza y desarrollo sostenible, 1998)

Aparte de la locución adverbial al cabo de, que siempre introduce números, también se crea la locución al cabal, que significa 'exactamente', 'perfectamente', 'completamente' y se usa como adverbio modal. Es bastante marginal, solamente 
encontramos 6 registros en el CDH. Se documenta a partir del siglo XVI, por lo cual cabe suponer una composición análoga a la locución al justo:

(99) No entienden estos quién es Dios, ni quién son ellos, ni qué es lo que le deben, ni tampoco el mar de males i vizios que tienen en su pecho. No saben que es Dios su Criador i Redentor, i que por esta razon lo deben entera obedienzia de todo lo que se contiene en su lei, i que por ella son malditos para siempre los que al cabal no la cumplieren toda. (Juan Pérez, Breve tratado de doctrina, 1560)

(100) y los que se casasen con sus hijas de ellos, por virtud de los privilegios que tenían, gozasen y fuesen libres de allí en adelante de la alcabala de todo lo que vendiesen que verdaderamente fuese de sus labranzas y crianzas dondequiera que lo vendiesen, y que de todo lo otro pagasen al cabal conforme á las leyes del cuaderno [...]. (Alonso de Santa Cruz, Crónica del Emperador Carlos V, 1550)

(101) que es el pronosticar verdad, aunque sea para mal; y esto no quatro o seis vezes, que podría ser acasso, sino toda la vida, como a my me á aconteçido sin aver errado en cinquenta años dos pronósticos, aviendo pronosticado cosas tan estrañas y extraordinarias, como en estos discursos se dexa ver, y aviendo los pronósticos salido tan al cabal, que me acusaron por ellos los que me avían de honrar y imitar, diziendo que no estavan escritas aquellas cosas y que sin duda era familiar el que tenía y no çiençia humana. (Juan Méndez Nieto, Discursos medicinales, 1606-1611)

El siguiente ejemplo muestra que al cabal, efectivamente, comparte rasgos semánticos con al justo $_{3}$ 'apretado, exactamente ajustado':

(102) Acá, cuando se corta un vestido, se toma la medida de pies a cabeza a la persona para quien es, o a la parte del cuerpo para quien se hace el vestido, para que ajuste y venga bien, de suerte que, si el vestido lo enllenásemos de paja o de otra cosa, es otro cuerpo semejante. Eso propio hizo Cristo, que tomó la medida a todos nuestros trabajos para vestirse de ellos y que saliese tan ajustada la compasión y piedad que de ellos habíe de tener, que viniese muy al cabal y que nadie tuviese trabajos que en Cristo no hallase una compasión a su tamaño. Así vemos que, cuando Cristo iba acompañado de mucha gente y le llegó a tocar aquella mujer del fluxo de sangre, dijo: Quis me comprimit? ¿Quién me aprieta? Y fue que la enfermedad y trabajo de aquella mujer, de que Su Majestad iba vestido, le apretaba por venirle tan al justo el remediar las necesidades de los hombres. Desta misma suerte nos hemos nosotros de vestir de Cristo: que las cosas y obras que hizo por el hombre nos aprieten, de suerte que nosotros andemos ajustados, según nuestras fuerzas, a su agradecimiento y al dolor y tormentos que por nosotros padeció. (San Juan Bautista de la Concepción [Juan García Gómez], Exhortaciones a la perseverancia, 1610-1612) 
En cuanto al uso adverbial de cabal, no hay datos claros que confirmen que se haya desarrollado plenamente tal adverbio corto. ${ }^{27}$ Solamente hemos encontrado casos en los que cabal se flexiona y concuerda en número y género con el sustantivo. Igual que en el caso de justo como adverbio flexionado (véase apartado 3.1.7.1), la interpretación de estos ejemplos es ambigua entre adjetivo y adverbio:

(103) tanta fue la gente que había en este valle, que muchos españoles dicen que, cuando se ganó por el marqués y ellos este reino, había más de veinte y cinco mil hombres, y ahora creo yo que no hay cabales cinco mil: tantos han sido los combates y fatigas que han tenido. [...] después que la hubieron pasado, no hubieron andado mucho trecho cuando de unos indios supieron estar el Inca cerca de allí en un alto que hacía la sierra, con no cabales ochenta indios, porque la demás gente había mandado ir adelante y él pensaba seguirlos después [...]. (Pedro Cieza de León, Las guerras civiles peruanas/Crónica del Perú, 1553-1584)

(104) Parto siempre la primera diferencia por la segunda, que son 12 por 6, cabales dos, y tantos son los pesos de plata o oro de dos quilates que se han de añadir a cada peso de 20 quilates para baxarlo a 8, con oro subido de 20 quilates. (Álvaro Alonso Barba, Arte de los metales, 1640)

(105) El primogénito de mi abuelo, y hermano mayor de mi padre, que nació cuando el suyo contaba ya cabales diez y seis años de su edad, servía tambien en milicias provinciales como mayorazgo de provincia [...]. (Antonio Alcalá Galiano, Memorias, 1847-1849)

Al parecer, la flexión intuitiva de cabal se ve también propulsada o reforzada por la combinación con numerales, que a su vez concuerdan con un sustantivo en plural. Por encabezar el sintagma, tendemos a una interpretación adverbial de cabal. En cambio, como adjetivo antepuesto al sustantivo se inserta entre el numeral y el sustantivo:

(106) quitándole el defensivo que en la cabeça tenía, con que sudó mucho y la calentura le abaxó notablemente, aunque le quedó buen golpe della; y no le turó la baxa que dio de dos cabales horas, porque en acabando de sudar tomó una almendrada [...]. (Juan Méndez Nieto, Discursos medicinales, 1606-1611)

27 Igual que en el caso de justo, el etiquetado semi-automático del CDH mezcla las etiquetas de «adjetivo» y «adverbio» en cabal y clasifica muchos usos adjetivales de cabal como «adverbio», lo cual imposibilita cuantificar los usos realmente adverbiales. 
Hemos encontrado un solo ejemplo del siglo XX donde este lexema se usa como adverbio de modo con el significado de cabal $_{2}$ 'perfecto, como tiene que ser':

(107) - ¡Más vale que sepas que no soy un tonto!

-Y tú... ¡más vale que sepas que es mejor prudencia!

- iVoy a picotearte, hasta desangrarte, o hablas cabal! (Miguel Ángel Asturias, El Alhajadito, 1961)

Igual que en otros adverbios cortos, este ejemplo de cabal muestra que su uso sobrevive actualmente en el español americano. A nuestro modo de ver, este ejemplo permite «reconstruir» (cf. Hummel 2014a; 2014b) una probable tradición oral de cabal como adverbio corto, concretamente como adverbio de modo, de la cual no hay registros escritos. Como indicamos en el apartado anterior, la familia léxica de cabo cuenta con una tradición patrimonial popular desde el latín vulgar hispánico, lo cual facilitaría el hipotético uso de cabal como adverbio corto en la lengua hablada.

Los ejemplos citados en este apartado son los únicos que encontramos de un uso adverbial o ambiguo entre adverbial y adjetival de cabal en el CDH. La mención de cabal como adverbio en algunos diccionarios actuales (véanse s.v. cabal: DLE 2014; Moliner 1998) no aclara si realmente se usa como adverbio de modo, ya que no se cita ningún ejemplo. Asimismo, según Alonso (1958, s.v. cabal), desde el siglo XVIII, cabal también aparece como adverbio con el significado 'cabalmente, justamente, precisa y perfectamente'. Sin embargo, no cita ejemplos. Al parecer, la mención de un supuesto adverbio cabal por algunos lexicógrafos se refiere solamente a su uso como marcador de afirmación, como indican los ejemplos citados en el DHLE (1933-1936):

«Cabal Adv. m. Cabalmente. ¿Y su cuñada de usted, tía de esos mozos? -Cabal.» (Iriarte, Obr., ed. 1805, citado en el DHLE [1933-1936, s.v. cabal])

Como analizaremos más adelante, esta clasificación de cabal como «adverbio de modo» es problemática a la vez que innecesaria, ya que es posible vincular los marcadores de afirmación a un origen adjetival (véase el capítulo 6 y especialmente el apartado 6.5.1).

\subsubsection{Síntesis: la diacronía de al cabo de, cabal, cabalmente y al cabal}

En conclusión, los datos analizados confirman que antes de que justo entrara entre el siglo XV y XVI en el campo semántico de exactitud, este significado se expresaba mediante cabal y al cabo de. Se documentan especialmente en textos 
medievales administrativos y técnicos, y la locución al cabo de remite hasta a una construcción del latín vulgar tardío. El significado de cabal 'exacto' se desarrolla a partir de la idea de 'completo, acabado, que llega al final'. Asimismo, cabalmientre 'exactamente' se documenta en la Edad Media. Se trata, pues, del lexema más antiguo del campo semántico de exactitud en español.

Cabal no es un préstamo del latín, sino que es una formación nueva de las lenguas iberorromances, sobre la base del sustantivo hereditario-patromonial cabo 'extremo'. Mientras que en el caso de justo y justamente observamos un desarrollo paralelo entre el español y el francés, en el caso de cabal, al cabo de y cabalmente, se trata de una voz propia de las lenguas iberorromances con arraigo en la lengua popular. Por ejemplo, en catalán, cabal 'justo, exacto' aparece en ese mismo contexto: Falta mig any cabal per a Nadal (Grup Enciclopèdia Catalana, s.v. cabal) ('medio año cabal'). Sin embargo, no existe un adverbio *cabalment en catalán. En portugués actual, cabal y cabalmente se usan principalmente con el significado 'completo, perfecto', igual que en español actual. En este sentido, el valor semántico de exactitud en las voces iberorromances cabal y cabalmente ha caído en desuso; al parecer, este par léxico ha sido desplazado por justo, preciso, exacto y sus respectivos adverbios en -mente.

La frecuencia de cabal en el CDH es notablemente más baja que la de justo, exacto y preciso (véase más adelante el apartado 4.1 para una visualización de las frecuencias comparadas). El hecho de que los cultismos justo y justamente además, influidos por el francés- estén mejor documentados en los textos antiguos que las voces iberorromances patrimoniales derivadas de cabo se debe, a nuestro modo de ver, a la escasa representatividad del registro coloquial y de la lengua hablada popular en los textos antiguos.

Aunque el uso de cabalmientre como adverbio de exactitud ('exactamente, precisamente') se documenta ya en el siglo XIII, no hay más ejemplos en el corpus. La Tabla 7 resume el recuento general de las primeras 100 ocurrencias de cabalmente por período en el CDH. Para mostrar la reciente desaparición de este adverbio, dividimos el siglo XX en el período anterior y posterior al año $1975{ }^{28}$

\footnotetext{
28 No elaboramos un corpus base de cabalmente (tal y como lo hicimos para los demás adverbios: 50 ocurrencias por medio siglo, sacadas del $\mathrm{CDH}$ nuclear), ya que cabalmente es mucho menos frecuente: en el siglo XVI, solamente se registran 34 ocurrencias y en el siglo XVII 42 en todo el CDH. A partir del siglo XVIII, hicimos un recuento de las primeras 100 ocurrencias en el CDH completo, ya que el corpus nuclear es insuficiente. Usamos cortes temporales más simplificados: siglo XVIII, siglo XIX, siglo XX (hasta 1974) y siglo XX (a partir de 1975). Esta última delimitación por el año 1975 sigue a los subcorpus del CDH (el subcorpus sincrónico empieza en el año 1975). Además, el año 1975 es también el que separa entre los corpus CORDE y CREA.
} 
Después de una sola documentación en Alfonso X, el adverbio vuelve a aparecer esporádicamente durante los siglos XVI y XVII, pero principalmente como adverbio de modo con el significado 'perfectamente, completamente'. Desde el siglo XVIII hasta mediados del siglo XX, predomina claramente el significado 'justa, exacta, precisamente'. Sin embargo, en el español contemporáneo, esta proporción se invierte. ${ }^{29}$

Tabla 7: Recuento de los significados de cabalmente en todo el CDH, máx. 100 ocurrencias por período.

\begin{tabular}{lcrrrrrr}
\hline & $1200-$ & $1501-$ & $1601-$ & $1701-$ & $1801-$ & $1901-$ & $1975-$ \\
& 1499 & 1600 & 1700 & 1800 & 1900 & 1975 & 2000 \\
\hline $\begin{array}{l}\text { cabalmente } \\
\text { cabalmente 'exacta, precisamente' }\end{array}$ & 1 & 3 & 9 & 77 & 94 & 78 & 10 \\
completamente' & & 31 & 33 & 23 & 6 & 22 & 90 \\
\hline
\end{tabular}

Es necesario matizar este recuento con la frecuencia relativa de cabalmente en el $\mathrm{CDH}$, ya que las franjas temporales no son equivalentes en cuanto al tamaño total del corpus. Para ello, proyectamos los datos obtenidos de nuestro recuento manual (los porcentajes deducidos de la Tabla 7) sobre los datos de la frecuencia relativa de cabalmente por cada millón de palabras en el $\mathrm{CDH}$ (nuclear y extensiones). ${ }^{30}$ El Gráfico 3 muestra el aumento y descenso de cabalmente en el CDH siguiendo la diferenciación según los dos significados básicos.

El gráfico muestra que la mayor frecuencia de uso de cabalmente se encuentra en el siglo XIX y este auge se debe claramente a su uso como adverbio de exactitud (cabalmente $)_{1}$ con valores equivalentes a precisamente, justamente y exactamente. Sin embargo, este uso ha desaparecido durante las últimas décadas del español

29 Preguntamos a varios hablantes nativos españoles, todos con formación académica de lingüistas, y nos confirmaron que solo conocían el uso de cabalmente como adverbio de modo con el significado 'perfectamente', 'enteramente', 'como tiene que ser'. Ninguno conocía la acepción 'exactamente, precisamente', aunque nos indicaron que los ejemplos citados de cabalmente 'precisamente, justamente' podrían entenderse.

30 Calculamos manualmente la frecuencia relativa de cabalmente en los períodos especificados en el gráfico, ya que los datos del recuento automático que ofrece el $\mathrm{CDH}$ para cabalmente son erróneos por haberse confundido los períodos. En el gráfico, la única ocurrencia de cabalmientre 'exactamente, precisamente' en el Medievo corresponde a una frecuencia relativa de 0,02 , por lo cual apenas se ve en el gráfico. 


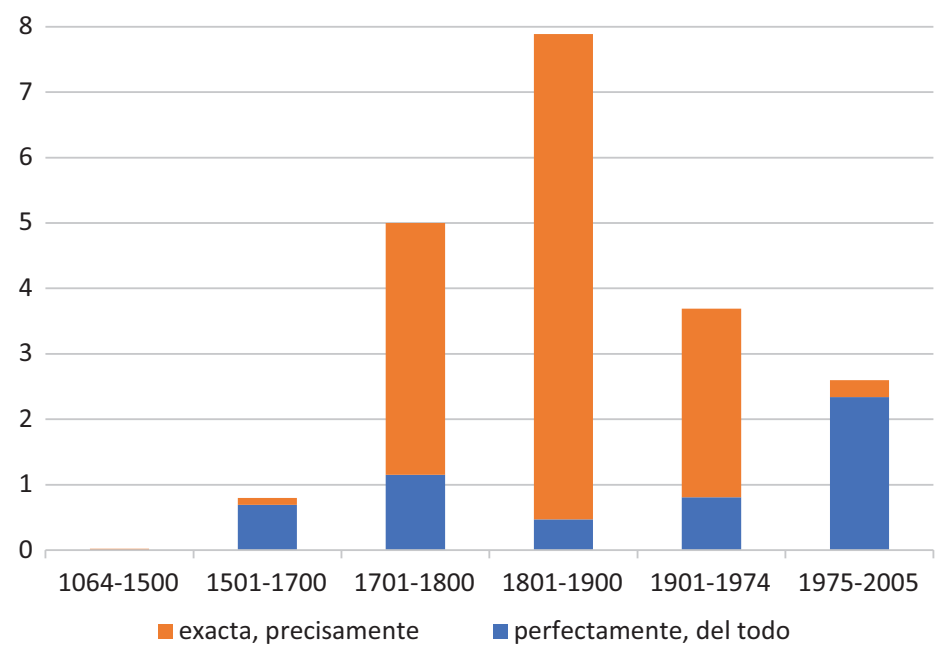

Gráfico 3: Frecuencia relativa normalizada (por millón de palabras) de cabalmente en el CDH. Cálculo de los significados a partir de la muestra base (100 ejemplos por período).

actual. Aparte del descenso abrupto de cabalmente $_{1}$ 'precisa, exactamente' en el siglo XX, llama la atención el aparente aumento o la «recuperación» de cabalmente ${ }_{2}$ 'perfectamente, del todo'. Creemos que este crecimiento se debe al desequilibrio geográfico del $\mathrm{CDH}$, que recoge un mayor número de textos latinoamericanos en las décadas recientes frente a décadas anteriores (Instituto de Investigación Rafael Lapesa de la Real Academia Española, 7-8). Efectivamente, en el período 19011974, las ocurrencias de cabalmente se reparten casi equitativamente entre España y América Latina, mientras que en el período 1975-2005, cabalmente se documenta dos veces más en textos latinoamericanos que en textos españoles. Más adelante (véase apartado 4.3.1) analizaremos las diferencias diatópicas de los adverbios de exactitud y veremos que cabalmente se ha conservado principalmente en América Latina, sobre todo, en México y Centroamérica. Por eso, el aumento de cabalmente 'perfectamente, del todo' en el último período es simplemente una distorsión por «efecto de corpus».

\subsection{Preciso y precisamente}

En la actualidad, la familia léxica preciso, precisamente, precisión y precisar tiene básicamente tres significados conceptuales: uno relacionado con el concepto de precisión y exactitud; otro correspondiente a 'fijo, formal' y, por último, el significado 'necesario, necesariamente'. 
En primer lugar, preciso $_{1}$ 'exacto, conciso, riguroso' se inserta en el campo semántico de la exactitud y la precisión. Aparece en varios contextos de uso:

«Dicho de instrumentos, 'que permite medir magnitudes con un error mínimo': Este instrumento es muy preciso: mide milésimas de milímetro.»

«Dicho de una cosa, 'perceptible de manera clara y nítida': Líneas precisas. Contornos precisos.»

«Dicho de una persona o de su expresión, 'concisa y rigurosa'.» (DLE 2014, s.v. preciso)

Asimismo, el verbo precisar $_{1}$ significa 'fijar o determinar de modo preciso' y el sustantivo precisión remite a la cualidad de preciso (DLE 2014, s.v. precisar, precisión). En cuanto al adverbio precisamente ${ }_{1}$, también es parafraseable por exactamente o justamente. Sin embargo, precisamente apenas se usa en la actualidad como adverbio de modo con los significados correspondientes que acabamos de mencionar para preciso: serían poco habituales usos como medir precisamente los milimetros 'con precisión', expresarse precisamente 'de manera concisa' o percibir algo precisamente 'claramente'. De hecho, el significado ‘con precisión' aparecía en la edición anterior del DLE (2001, s.v. precisamente), pero se quitó en la edición actual del 2014.

Los ejemplos citados por los diccionarios consultados corresponden principalmente a los diversos usos discursivo-pragmáticos de precisamente. Así, el DLE (2014, s.v. precisamente) menciona que se usa frecuentemente con sentido enfático y según el CLAVE (1999, s.v. precisamente) «[s]e usa mucho para subrayar una contradicción o la inoportunidad e inconveniencia de algo». Para Moliner (1998, s.v. precisamente), es un «adverbio enfático» que se emplea «también para subrayar una contradicción o la inoportunidad o inconveniencia de una cosa» o que produce un efecto de contradicción:

\footnotetext{
Eso era precisamente lo que quería. (CLAVE 1999, s.v. precisamente)

¿Tenías que decirlo precisamente ahora? (DLE 2014, s.v. precisamente)

Llegó precisamente cuando yo salía de casa. (Moliner 1998, s.v. precisamente)
}

A pesar de que Moliner (1998, s.v. precisamente) considera que este adverbio tiene una «significación correspondiente a la de preciso», opinamos que el adjetivo y el adverbio se han diferenciado bastante: preciso mantiene, sobre todo, significados conceptuales relacionados con el concepto de precisión, mientras que precisamente ha generalizado usos procedimentales de focalización (énfasis, contradicción, etc.). Nos centraremos en este capítulo en los significados conceptuales básicos, ya que los valores procedimentales de precisamente - que surgen de este primer valor semántico de exactitud y precisión- se analizarán en una sección propia (véase capítulo 5). 
En segundo lugar, el significado preciso $_{2}$ 'fijo, formal, determinado' es poco frecuente actualmente y solo parece haberse mantenido en el verbo precisar $_{2}$ con el matiz semántico 'obligar, forzar determinadamente y sin excusa a ejecutar algo’ (DLE 2014, s.v. precisar).

En tercer lugar, el significado preciso $_{3}$ 'necesario, inevitable, indispensable' aparece, sobre todo, en la fórmula «ser + preciso = ser necesario, hacer falta» (Moliner 1998, s.v. preciso):

Es preciso que vengas [...] (CLAVE 1999, s.v. preciso)

Tomaremos las medidas precisas. (DLE 2014, s.v. preciso)

Asimismo, el verbo precisar $_{3}$ significa 'ser necesario o imprescindible' (DLE 2014, s.v. precisar). En cambio, precisamente 3 'necesariamente' apenas se usa, a diferencia del portugués, donde es habitual. No aparece en la versión más reciente del DLE (2014) ni en el diccionario de Moliner (1998). En ediciones anteriores del DLE aparecía como 'necesaria, forzosa o indispensablemente; por una necesidad absoluta o sin poderse evitar' (DLE 2001, s.v. precisamente). Asimismo, se cita en el CLAVE (1999, s.v. precisamente) el significado 'necesariamente', pero sin ejemplo. De nuevo, observamos una asimetría: este tercer significado se ha mantenido en el adjetivo preciso y en el verbo precisar, pero parece haberse perdido en el adverbio y no parece haberse desarrollado en el sustantivo precisión.

En cuanto a las clases de palabras, preciso se usa solamente como adjetivo, no parece haber desarrollado un uso adverbial o sustantival. Por tanto, al contrario de justo, no es polifuncional en cuanto a las categorías gramaticales. En los apartados que siguen, analizaremos la diacronía de los tres significados básicos de la familia léxica preciso, precisamente, precisar y precisión. Nos centraremos, sobre todo, en el adjetivo y adverbio, pero para un panorama más completo de los cambios semánticos, tendremos en cuenta toda la familia léxica.

\subsubsection{Origen léxico (PRAECīsus en latín) y préstamo culto}

En latín, PRAECīsus significa 'cortado de, separado de, cortado a pico, escarpado, abrupto, (re)cortado, abreviado' (Machado 1967, s.v. preciso; Blánquez 2012, S.v. PRAECIsus; Segura Munguía 2013, S.v. Praecīsus). Praecīsus, -A, -UM es el participio perfecto de PRAECİDO, -CĪDĪ, -CĪsUM, -ERE (TLL 2009, s.v. PRAECĪsus, PRAECĪDO) 'cortar bruscamente', con lo cual deriva de CAEDERE 'cortar' (Corominas/Pascual 1997, s.v. decidir); es decir, se formó por PRAE más CAEDERE (TLL 2009, 
S.V. PRAECİDO). Literalmente, esta composición significa 'cortar por delante' y, en general, ‘separar cortando', ‘quitar', 'abreviar’ y ‘suprimir’ (de Miguel [1867] 2000, S.V. PRAECISUS; Blánquez 2012, s.v. PRAECIDO). De la misma familia léxica proviene el sustantivo latín PRAECISIO, -ŌNIS ‘corte’, ‘concisión' (Blánquez 2012, s.v. PRAECISIO), que se presta como PRECISIón al español (DLE 2014, s.v. precisión).

En el contexto del lenguaje y de la retórica, PRAECīsus se usa con el significado 'breve, conciso, resumido, truncado' (Machado 1967, s.v. preciso; Blánquez 2012, s.v. PRAECISUS) y se refiere a palabras breves a modo de staccato (Glare 2012, s.v. PRAECĪsus). Así aparece, por ejemplo, en el gramático latino Donato (siglo IV): ECLIPSIS EST DEFECTUS QUIDAM NECESSARIAE DICTIONIS, QUAM DESIDERATA PRAECISA SENTENTIA (TLL 2009, S.v. PRAECİDO) ('La elipsis es un cierto defecto en una dicción necesaria, que requiere una oración abreviada').

Ese mismo significado aparece en el adverbio PRAECīsē (TLL 2009, s.v. PRAECİDo) que se usa en el sentido de 'en pocas palabras, brevemente, concisa, categóricamente' (Segura Munguía 2013, s.v. PRAECISE), 'sucinta, lacónicamente' (de Miguel [1867] 2000, s.v. PRAECISE; Blánquez 2012, s.v. PRAECISE) y 'de manera abreviada, elíptica' (Glare 2012, s.v. PRAECISE), como por ejemplo, en PRAECISE DICITUR 'se dice en pocas palabras' (Blánquez 2012, s.v. PRAECISE). Cicerón también usa este adverbio en el sentido de 'de manera tajante, categórica’: PRAECISE NEGARE 'rehusar categóricamente’ (Blánquez 2012, s.v. PRAECISE).

En español, preciso es un latinismo del siglo XVI (Corominas/Pascual 1997, s.v. decidir), o sea, un préstamo culto bastante tardío. Llama la atención que, por un lado, solo retoma algunos de los usos mencionados del latín, y por otro, aparece con una serie de significados nuevos: según Alonso (1958, s.v. preciso), desde la aparición de preciso se usan tanto el significado 'necesario, indispensable' como 'puntual, fijo, exacto, cierto, determinado'. Ambos no existían en latín.

Aparte de un posible origen latino del préstamo, también es probable una influencia francesa, ya que, en francés, tanto el adjetivo précis 'determinado, definido’ como el verbo préciser datan ya del siglo XIV (véanse s.v. précis: Gamillscheg 1969; DHLF 2000). Por su parte, el verbo precisar es una formación nueva sin origen latino (Segura Munguía 2013, s.v. precisar). En los apartados que siguen, analizaremos los significados que adquieren preciso, precisamente y precisar en español y su posible origen francés.

En cuanto al significado primario de PRAECīsus, Alonso (1958, s.v. preciso) observa que el español preciso ‘separado, apartado o cortado’ se mantiene hasta el XVIII. En los diccionarios actuales, este significado ya no aparece. Solamente la edición anterior del DLE (2001, s.v. preciso) califica el significado 'separado, apartado o cortado' como «desusado». No se documenta en nuestra muestra base, lo 
cual nos indica que el significado etimológico de preciso fue marginal en español. Además, en el contexto del terreno y paisaje, el latín PRAECĪsus hace referencia a precipicios o acantilados abruptos y escarpados (Glare 2012, S.v. PRAECISUS). Ese uso de preciso ‘abrupto, escarpado’ también se pierde en español. Solamente hemos encontrado dos ejemplos en la muestra base:

(108) Aquí habla el sátrapa al penitente, diziendo: «¡Oh, hermano! Has venido a un lugar de mucho peligro y de mucho trabaxo y espanto, donde está una barranca precisa y de peña tajada que nadie que cae una vez en ella puede jamás salir. (Fray Bernardino de Sahagún, Historia general de las cosas de Nueva España, 1576-1577)

(109) La fortaleza de Chagres es de una situación admirable por estar fundada sobre un alto peñasco escarpado hacia la mar, desde donde domina el fondeadero preciso de las embarcaciones grandes, y cubre con sus fuegos, por otra parte, la entrada del río. (Jorge Juan/Antonio de Ulloa, Noticias secretas de América, 1747)

\subsubsection{Preciso $_{1} /$ precisamente $_{1}$ 'exacto, conciso'}

En español, preciso $_{1}$ 'exacto, conciso’ y precisamente ${ }_{1}$ 'exacta, concisamente’ frecuentemente aparecen en relación con la expresión lingüística, es decir, retoman un contexto de uso que ya existía en el latín PRAECīsus y PRAECĪsĒ. En el CDH, encontramos una sola documentación de este adjetivo ya en el siglo XIII. ${ }^{31}$ Por la ausencia de más documentación de preciso hasta tres siglos más tarde, parece tratarse o bien de una errata de copia posterior - el testimonio en el que se basa el CDH data del siglo XV- o bien de un préstamo «individual», que toma como modelo el latín PRAECISUS 'conciso, breve'. Sería, pues, una innovación singular que (todavía) no cuaja en la lengua:

(110) El callar en su lugar es buen seso, pocos omes lo fazen. [...] La lengua del que á seso es condensada detrás su coraçón. Non se osa ninguno fablar sinon omne sabio o omne nescio, el nescio porque es nescio, el sabio porque sabe fablar en su lugar e callar en su lugar. E el que non sabe prescio al callar quéxas’ por fablar. Non á cosa que más deva seer precisa luengamente que la lengua del omne. Gana omne toda vía por su oreja e non puede perder e, a las vezes, pierde omne por su lengua más de lo que gana. (Anónimo, Libro de los cien capítulos, 1285)

31 Este mismo ejemplo aparece en el CORDE. Sin embargo, su autenticidad es cuestionable, ya que el Libro de los cien capítulos recibe la etiqueta roja del Cordemáforo de Rodríguez Molina/ Octavio de Toledo y Huerta (2017). 
Tanto en francés (DHLF 2000, s.v. précis) como en español, este uso de preciso 'conciso, breve' vuelve a aparecer en el siglo XVI. En español aparece paralelamente en el adverbio precisamente ${ }_{1}$ 'brevemente, concisamente':

(111) Diré aora lo que pretendo hazer en esta historia. Yo al principio propuse escrivir precissamente la vida del bienaventurado padre nuestro Ignacio y desembolver y descubrir al mundo las excelentes virtudes que él tuvo encogidas y encubiertas con el velo de su humildad. Después me pareció ensanchar este mi propósito y abraçar algunas cosas más. (Pedro de Ribadeneira, Vida de San Ignacio de Loyola, 1583)

En este contexto de uso, el francés précis califica a un lenguaje que se expresa de manera nítida y sin términos superfluos (DHLF 2000). Sin embargo, preciso y precisamente solo se usan marginalmente con el significado 'expresión lingüística breve' en nuestra muestra base, ya que hacia finales del siglo XVI aparece también como préstamo culto el adjetivo conciso 'breve', que deriva igualmente de CAEDERE 'cortar' (Corominas/Pascual 1997, s.v. decidir) y que toma este mismo significado:

(112) Obliga el uno a brevedad concisa;

que aunque la demasiada luz desama,

precia la elocución peynada i lisa. (Bartolomé Leonardo de Argensola, Rimas, 1592-1631)

(113) Y de aquí es también que, viendo los vizcaínos lo mucho que se significa con pocos vocablos de su lengua, pensando que es así en la castellana, quieren hablar tan conciso y abreviado, que los llaman cortos como vizcaínos, y se ha tomado en proverbio. (Mateo Luján de Saavedra (Juan Martí), Segunda parte de la vida del pícaro Guzmán de Alfarache, 1602)

Al parecer, hay un reparto de matices semánticos: mientras que conciso hace referencia a la expresión lingüística breve, preciso y precisamente cambian su significado en este mismo contexto y empiezan a usarse para la descripción lingüística exacta, correcta y cierta:

(114) Lo que terná de longura y anchura y en contorno, porque ha muchos años que estuve en ella y no pensaba en la describir, no puedo bien acordarme para precisamente lo decir; paréceme que terná más de treinta leguas en luengo y más de veinte y de veinticinco quizás en ancho. (Fray Bartolomé de las Casas, Apologética historia sumaria, 1527-1550)

(115) mandamos que la dicha descripción se haga con mucha diligencia y muy precisa y cierta, y la forma que se ha de tener en hacer mandamos que sea procediendo de la Geografía, que es la descripción general de toda la tierra, la cual haga el nuestro Cosmógrafo mayor [...]. (Anónimo, «Ordenanzas para la formación del libro de las descripciones de Indias», 1573)

En este sentido, creemos que de preciso 'conciso, breve, que no tiene cosas superfluas' deriva la idea de 'exacto y claro', ya que el lenguaje conciso se limita a lo 
esencial y, con ello, es más exacto y más claro que un lenguaje rimbombante y sobrecargado. Así, preciso y precisamente pasan de significar 'abreviado, conciso' a significar 'exacto, nítido, claro, acertado':

(116) Pondré las proprias palabras de Mr. Gofredo, pues no puedo usar de otras más claras ni más precisas, aunque añadiré de letra cursiva tal qual advertencia mía a favor de los más tardos en entender. (Benito Jerónimo Feijoo, Theatro Crítico Universal o discursos varios en todo género de materias, para desengaño de errores comunes $V, 1733$ )

Este mismo uso también se desarrolla en el francés précis que hace referencia, desde el siglo XVII, a una representación clara y exacta (DHLF 2000, s.v. précis). Finalmente, preciso ‘nítido, claro' amplía su contexto de uso y no solo hace referencia a expresiones de la lengua, sino también a percepciones visuales en general:

(117) Soñó que de las tres mujeres se perfilaba el retrato preciso de una figura solitaria, y entonces sintió miedo. (Francisco Javier Satué, La carne, 1991)

(118) Acercóse Teresa aguzando el oído con intento de percibir algún ruido del interior de la huerta... Oyó voces confusas, pasos, cantos del gallo... Su viva imaginación le fingió imágenes precisas de lo que allí dentro pasaba. (Benito Pérez Galdós, O’Donnell, 1904)

\subsubsection{Preciso $_{1} /$ precisamente $_{1}$ 'exacto' en el contexto de medidas y cuentas}

El valor semántico de exactitud se desarrolla paralelamente en otro contexto: la medición del tiempo y del espacio. En francés, précis se usa ya al principio del siglo XV en el sentido de 'exactamente determinado en la medida (especialmente, del tiempo)’ (DHLF 2000, s.v. précis). En español, este uso es más tardío (siglo XVI), por lo cual no descartamos una posible influencia del francés.

Es llamativo el uso del adverbio precise, que parece imitar al latín PRAECISĒ, en textos de finales del siglo XV. Se usa en el sentido de 'exactamente' en el contexto de números:

(119) Sant Gregorio constituyó precise la música en VII letras, «Quia numerus septenarius celeberrimus est», porque los planetas son siete, los climas habitables, siete, los dones del baptismo, siete, los pecados mortales. [...] Cada specie tiene tantas variaciones quantos interuallos contando precise de diapente fasta diapasón. (Domingo Marcos Durán, Glosa sobre Lux bella, 1498) 
A principios del siglo XVI, se documentan en el $\mathrm{CDH}$ preciso $_{1}$ 'exacto' y precisamente $_{1}$ 'exactamente' en el contexto de la determinación exacta de localizaciones e indicaciones temporales:

(120) los xaraues, píldoras, confeciones, letuarios, \& mayormente las opiatas, que no se han de dar ante del sexto mes o ante de vn año, e por que sepa el médico el tiempo preciso en que fueron hechas essas medicinas, y por que, congruamente y con buena consciencia, y también sin peligro, las sepa dar quando fuere tiempo. (Alfonso Rodríguez de Tudela, Traducción del Compendio de boticarios, 1515)

(121) Cerca de este punto es de notar que, en cualquier sitio que el paraíso esté, se puede entender estar al oriente. La razón es porque cualquiera punto en la tierra se puede entender estar al oriente por respecto y en comparación del cielo o por respecto de diversos sitios de la tierra, si no es por respecto de los dos polos, por ser inmobles o no movibles. Y así, por decir estar al oriente, no por eso se determina cierto y preciso lugar de la tierra en que tenga su sitio el paraíso.

[...] si en isla o tierra firme, puesto sea el paraíso terrenal, decimos que en qué lugar o debaxo de qué parte del cielo sea su sitio, cierta, determinada y precisamente, nadie de los que vivimos y vivieron antes de nos, mientras vivían, ni lo sabemos ni lo supieron [...]. (Fray Bartolomé de las Casas, Historia de las Indias, 1527-1561)

En nuestra opinión, la relación semántica entre el significado originario concreto de preciso ‘abreviado, recortado' y el nuevo significado abstracto 'exacto' en la medición del tiempo o en la determinación de un lugar surge a partir de la siguiente asociación: para determinar de manera nítida un punto exacto, hay que ser conciso y acotar o reducir rigurosamente el espacio o el tiempo. En este sentido, el significado de preciso 'perceptible de manera clara y nítida' enlaza con la idea de 'recortado, abreviado’. Además, el significado ‘exacto’ en la medición científica también podría vincularse al matiz 'exacto' que surge en el contexto del lenguaje preciso y sería pues el resultado de una extensión de los contextos de uso de preciso $_{1}$.

En el siglo XVI, aparece el verbo precisar. Como muestra el siguiente ejemplo, precisar, preciso y precisamente se usaban frecuentemente en el lenguaje técnico y científico para la medición exacta del tiempo o del espacio con instrumentos científicos:

(122) Con tu astrolabio o cuadrante aguarda cuando el sol o la luna estuviere en altitud sobre el horizonte cuarenta y cinco grados precisos, y entonces nota el fin de la sombra de cualquiera cosa y haz allí una señal, desde la cual mide por una línea recta cuantos pies o estados hay hasta el pie de la tal cosa [...].

Y la primera vez deben tener otro instrumento con que se pase un hora precisa, y en el punto de ella comience la arena a correr, y corra tanto hasta que sea cumplida una hora y luego pare, y después quiten la arena que sobrare y no haya pasado. [...]

Primeramente son necesarios dos compases de un tamaño cuya grandeza no exceda a un palmo. Deben ser perfectos y de amoroso juego en abrir y cerrar; deben haber las puntas agudas a fin que puedan precisar los lugares que tocaren. 
[...] solamente hemos de hacer todo el lineamiento que haríamos para carta general. Y así es acabado todo el artificio y traza de la dicha carta de marear, la cual tanto más será verdadera y perfecta, cuanto más precisamente en ella fueren señalados los dichos puntos y líneas que hemos tratado.

[...] habiendo partido de un punto y caminado por alguno de los vientos de la aguja, y notar por cuál, y en cabo de un día o dos o más mirar la altitud del sol a mediodía, precisamente con su instrumento, o mirando la declinación que el sol tiene el tal día, y hacer la cuenta conforme a las reglas que tratan de esto. (Alonso de Chaves, Quatri partitu en cosmografía práctica, y por otro nombre espejo de navegantes, 1527)

(123) E deve procurar de llevar instrumentos muy precisos e quanto mayores mejores. E no tener por trabajo tomar el altura muchas vezes e hazer lo siguiente.

[...] Lo otro por se errar en el altura, lo qual puede ser en una de tres maneras. La una por los instrumentos no ser verdaderos y precisos; o por yerro de cuenta; o por el piloto no tomar el altura precisamente por no ser muy exercitado. (Francisco Falero, Tratado del Esphera y del Arte del Marear, con el regimiento de las alturas, con algunas reglas nuevamente escritas y muy necesarias, 1535)

En este mismo discurso científico-matemático del siglo XVI, aparece el sustantivo precisión 'exactitud':

(124) el relox, según avemos dicho, de arena muy escogida, que quando queráys tener dos, o tres o más reloxes de todas suertes para cotejar los unos con los otros, tanto más os satisfaréys en la precisión de las horas y minutos, que son assí en el puerto donde os embarcastes, como en el golfo donde os halláys. (Andrés de Poza, Hydrografía, la más curiosa quehasta aquí ha salido a luz, en que, demás de un derrotero general, se enseña la navegación por altura y derrota, 1585)

En ningún diccionario encontramos mención del uso de preciso como adverbio corto. No obstante, en el CDH preciso se documenta muy esporádicamente con funciones adverbiales; en la muestra base encontramos tres ocurrencias. El uso esporádico de preciso como adverbio se limita al significado 'exactamente' y al siglo XVI:

(125) Y si todo el camino de un lugar al otro no fuere navegable derechamente, o que haya de doblar alguna tierra, o que el tal rumbo de la carta no $v a$ preciso al lugar querido, en tal caso se harán dos navegaciones, o las que más fueren menester, guiando primeramente la nao por el rumbo más preciso o paralelo al primer lugar o punto [...]. (Alonso de Chaves, Quatri partitu en cosmografía práctica, y por otro nombre espejo de navegantes, 1527)

(126) Este tiempo se puede saber de dos maneras: la una por epheméridas o almanach o algunas otras tablas o lunario y por esto se sabe preciso el día, hora y minuto de la conjunción y opposición; [...] cuelga el astrolabio de la armilla y pon el alhidada contra el sol y álçala o báxala en el quarto graduado hasta que el rayo del sol entre por el agujero pequeño de la pínola y dé preciso en el otro agujero pequeño de la otra pínola; (Martín Cortés Albacar, Breve compendio de la esfera y de la arte de navegar, 1551) 
Solamente hemos detectado otro ejemplo de preciso como adverbio en el siglo $\mathrm{XX}$, cuando los adverbios cortos se generalizan y se aceptan en la escritura:

(127) Son las palabras, señores, ampolluelas de vidrio que cada cual hincha a su guisa de significado, y acaso el valor decisivo de la ciencia no consista en otra cosa que en dotar a los vocablos de significaciones exactas en las cuales tengamos todos que convenir. Mas, por lo menos, ciencia es hablar preciso. (José Ortega y Gasset, Personas, obras, cosas, 1904-1916)

Por extensión metonímica, el adjetivo español preciso y el francés précis (DHLF 2000) también se aplican a personas que se expresan de manera clara o a personas que trabajan con exactitud:

(128) No tiene demasiado sentido seguir porque lo que sigue ahora pertenece al terreno de lo estrictamente científico y lo exacto y - a pesar de mi pericia de identificador crónico- yo nunca fui ni seré una persona precisa. (Rodrigo Fresán, La velocidad de las cosas, 1998-2002)

\subsubsection{Preciso $_{2} /$ precisamente $_{2}$ 'fijo, formal'}

El primer significado del francés précis es el significado abstracto de 'determinado, fijo', que califica aquello que se sitúa en un sitio bien determinado; este uso remite a la metáfora de 'recortado mentalmente y por el pensamiento' y se atestigua en el siglo XIV (DHLF 2000, s.v. précis). Asimismo, el adverbio francés précisement data ya del siglo XIV (DHLF 2000, s.v. précisement). Este uso es más tardío en español: a finales del siglo XV, encontramos algunas ocurrencias de preciso en el lenguaje jurídico con el significado ‘fijo, determinado, formal':

(129) por el dicho señor don Juan y señora doña Leonor o por qualquier dellos o para qualesquier sus herederos y descendientes que dellos hobiere titulo y causa de subçeder que fagan obserbar y guardar e mantener preciso e ynbiolablemente lo contenido y asentado en este dicho contrato [...]. (Anónimo, «Carta concejil de merced», 1484, Colección documental del archivo municipal de Hondarribia)

En el siguiente ejemplo, se fija un plazo determinado para un decreto real:

(130) En los dias passados, por algunas justas causas, respectos y consideraciones, nuestro reyal animo a esto dignamente mouientes, con nuestro reyal edicto general, prouehimos, ordenamos y mandamos que, dentro cierto termino, preciso y peremptorio, en el dicho nuestro edicto general expressado, todos y qualesquiere judios, assi hombres como mugeres, que stouiessen e se fallassen en nuestros reynos y senyorios, houiessen de sallir y vaziar de aquellos [...]. («Fernando concede salvoconducto a los judíos», 1493, Documentos sobre relaciones internacionales de los Reyes Católicos, I) 
Así pues, preciso $_{2}$ se atribuye a un espacio de tiempo determinado y fijo que es obligatorio de cumplir (nótese la combinación frecuente con perentorio 'definitivo'). En este mismo contexto jurídico y también en el siglo XV, aparece el verbo precisar 'determinar y fijar formalmente':

(131) Cédula de doña Isabel sobre diversas gestiones encomendadas por el concejo al jurado Juan Alemán y que se precisan en las cédulas siguientes. (Tumbo de los Reyes Católicos del concejo de Sevilla, 1476)

Asimismo, precisamente ${ }_{2}$ aparece con el significado 'formalmente, de manera fija' en cuanto a la ejecución de una orden judicial. Este uso aparece en el siglo XVI:

(132) para conocer, juzgar y decidir entre todos los sujetos de Su Majestad, de cualquiera de sus Reinos, que trataren y negociaren; en estas partes, el cual ejercitará la dicha justicia y la hará ejecutar precisa y realmente y de hecho sin contradicción ni impedimento alguno del dicho Rey ni de sus Oficiales, los cuales no se entremeterán ni estorbarán [...]. (Anónimo, fragmento, 1535 [Alonso de Santa Cruz, Crónica del Emperador Carlos V, c1550])

(133) alcanzaron de él que se le cortase la mano derecha, la cual se ejecutó en él, y lo desteró de toda las provincias del Perú. Asimismo desterró de la tierra precisamente a don Alonso de Montemayor, Jerónimo de la Serna, Diego de Urbina, Juan de Saavedra, Martín Cortés, Juan de Guzmán y a otros, porque tuvo atención que no le podían ser buenos amigos [...]. (Pedro Gutiérrez de Santa Clara, Quinquenarios o Historia de las guerras civiles del Perú, 1549-1603)

Un contexto de uso frecuente de preciso $_{2}$ 'fijo, formal, determinado' es el contexto de un plazo temporal fijo:

(134) Suplicamos a V. M. mande ver y considerar todo lo suso dicho, y pues tanto ba en ello mande establecer y ordenar de manera que a lo menos que el Armada de Galeras de España no salga de la demarcracion della, y guarde y defienda las costas del dicho mar mediterraneo de Perpiñan hasta el estrecho de Gibraltar, o hasta el rio de Sevilla: y Vuestra Magestad mande señalarles tiempo preciso que sean obligados a andar en corso y en la dicha guardia sin que de ello osen exceder: porque en esto hara V. M. servicio muy señalado a nuestro Señor, y gran bien y merced a estos reynos. (Anónimo, Cortes de Toledo de 1559 que comenzaron el 11 de diciembre de 1559 y concluyeron el 19 de noviembre de 1560, 1559-1560)

(135) Yo nunca supe en término preciso escrivir cuatro versos concertados, ni hazer, como otros, libros de improviso. (Lupercio Leonardo de Argensola, Rimas, 1579-1613) 
En el ámbito temporal hay ambigüedad -al menos desde una perspectiva del español actual- entre ‘fijo, formal, determinado’ y ‘exacto', en los casos en los que se fija el número exacto de un plazo o término:

(136) seis días de carcel con prisiones y si fuere persona que no tuviere de que pagar los dichos mil maravedis sea traido a verguenza e desnudo medio cuerpo con soga a la garganta y destierro de dos meses precisos; la pena de dinero por la segunda vez sea doblada y asi el destierro y dias de prisión y ademas de incurrir en la dicha pena doblada, a su costa torne a poner el arbol que así cortare [...]. (Anónimo, Antiguas ordenanzas para la conservación del Monte Castañar de la villa de Béjar y para el buen gobierno de ella, 1571)

Asimismo, precisamente es ambiguo entre 'determinadamente, fijamente' y 'exactamente' en este ejemplo:

(137) los cuales treinta mil ducados son de los que se cogen de los derechos de once y seis al rnillar, que algunos años ha que lo mando recoger, y que adelante se contiene, estos mismos treinta mil ducados de este depósito se conviertan y empleen todos en el cumplimiento y efetuación de la dicha manda, y en aquellas mismas tres obras pías precisamente, y no en otra cosa alguna. (Anónimo, fragmento, 1554 [Fray Prudencio de Sandoval, Historia de la vida y hechos del Emperador Carlos V, 1604-1618])

Como muestran los ejemplos citados, preciso 'fijo, determinado, formal' y precisamente 'de manera fija, determinada, formal' implican también el componente semántico ‘forzoso, obligatorio’. Efectivamente, la consulta lexicográfica en el NTLLE muestra que se usaba con ese significado en los siglos XVIII y XIX: Terreros y Panda (1786-1788) define preciso como 'forzoso, inexcusable, necesario, indispensable’. Asimismo, encontramos esta definición del siglo XIX:

«llamamos preciso a lo necesario, a lo indispensable [...] lo preciso es el resultado, la consecuencia de una necesidad, de un deber, de una obligación: lo preciso es forzoso» (Zerolo 1895, s.v. preciso).

Estos dos diccionarios son los únicos que mencionan explícitamente la acepción 'forzoso'. Según los ejemplos de nuestra muestra base, este uso de preciso era propio del lenguaje jurídico:

(138) De todo lo que huvo de que dar quenta a vuestra magestad deste Gouierno del Rio de la plata la di copiosa el año pasado de 608 y cunpliendo con tan preçisa obligaçion la dare aora de lo que despues aca se a ofreçido y del estado de las cosas del para que vuestra magestad este enterado de todo y provea lo que mas convenga a vuestro Real seruiçio. (Hernando Arias de Saavedra, «Carta al rey, 8 de mayo de 1609», 1609) 
Esta acepción aparece como fórmula jurídica que se opone al término voluntad (o derivados como voluntario):

(139) Que ningún soldado, proprio motu, entre alojar en iglesia, monesterio ni hospital, ni en casas o granjas a ellos pertenecientes, so pena de ser puesto en prisión por tiempo preciso o a voluntad. (Sancho de Londoño, Discurso sobre la forma de reducir la disciplina militar a mejor y antiguo estado, 1568)

(140) Lo mesmo es del voto de ir a Santiago, que entienden haber satisfecho con ir a visitar su iglesia. Otro jura de no jugar en tres o cuatro años; quebrántalo al momento diciendo que no los juró precisos, sino voluntarios, y que los cumplirá cuando quisiera; que suplica a sus amigos no le aprieten, como si lo hubiese con ellos. (Francisco de Luque Fajardo, Fiel desengaño contra la ociosidad y los juegos, 1603)

Asimismo, se observa el uso de precisamente 'de manera fija y determinada' con el matiz 'obligatoriamente, indispensablemente' en lo que atañe el modo de cumplir una orden legal:

(141) Santiago del mismo año de 1536, y las otras desde en adelante á los dichos términos, y que aquellos que tendrán cargo y comisión de cobrar y recibir los dichos derechos é imposiciones serán tenidos de pagarla precisamente á los dichos términos, y que en falta de esto les que tendrán cargo de la dicha Goleta podrán llanamente y de su propia autoridad entrar in continenti en la cobranza, receptoría y administración de los dichos derechos [...]. (Anónimo, fragmento, 1535 [Alonso de Santa Cruz, Crónica del Emperador Carlos V, c1550])

(142) vayan a ver lo que cada uno tiene ordenado y si han cumplido con el mandato que les fue hecho, y precisamente mando que se haga en la forma susodicha, sin que se les pueda conmutar a dineros, ni pedírselos por lo susodicho so pena de doscientos pesos en que doy por condenadas a las dichas justicias y regimiento [...]. (Anónimo, «Ordenanzas para la ciudad de Cuzco y sus términos», 1572 [Disposiciones gubernativas para el virreinato del Perú dadas por Francisco de Toledo])

Este significado relacionado con la obligación legal y fijada es poco frecuente en la actualidad, y solamente parece haberse conservado el verbo precisar $_{2}$ 'obligar, forzar determinadamente y sin excusa a ejecutar algo' (DLE 2014, s.v. precisar). En francés, précis ‘fijo, formal, determinado’ no parece haber desarrollado el matiz semántico 'obligatorio, forzoso'.

\subsubsection{Preciso $_{3} /$ precisamente ${ }_{3}$ 'necesario'}

En cuanto a este tercer significado de preciso, precisamente y precisar, la idea de necesidad absoluta e indispensable solo surgió en las lenguas iberorromances. La innovación semántica de preciso $_{3}$ 'absolutamente necesario, indispensable' es 
propia del castellano y portugués (Corominas/Pascual 1997, s.v. decidir) y no existe en francés. ${ }^{32}$ El diccionario etimológico francés (FEW 1922-2002) menciona el uso de précis 'nítido, formal' en cuanto a órdenes y demandas, pero no parece haberse dado el desarrollo semántico de 'forzoso, indispensable, absolutamente necesario'.

Hay dos posibles vías para reconstruir la evolución semántica del significado 'necesario'. Por un lado, según las explicaciones de Machado (1967, s.v. preciso) para el portugués, la idea de ‘cortado, separado' dio lugar a la idea de 'falta' y, consiguientemente, a la idea de necesidad. Sin embargo, como mencionamos anteriormente (véase apartado 3.3.1), el significado latino etimológico de 'cortado, separado' es marginal en español y no se documenta en nuestra muestra base. Por eso, no nos parece probable que sea este el significado base para la innovación semántica. Además, no encontramos ejemplos donde preciso implique la idea de «falta».

Por otro lado, los ejemplos de nuestra muestra base indican que el significado 'necesario, indispensable' surge en contextos jurídicos-administrativos y en relación con los matices semánticos 'obligatorio, forzoso' que surgen de preciso $_{2}$ 'fijo, formal'. A nuestro modo de ver, el rasgo semántico de 'forzoso, obligatorio' es el que permite contextos puente ambiguos entre preciso $_{2}$ 'fijo, determinado, formal' y preciso $_{3}$ 'indispensable, necesario' en el lenguaje jurídico. Ya que el matiz 'forzoso, obligatorio' no se da en francés (véase apartado anterior), précis no pudo desarrollar el significado 'necesario, indispensable'.

Ya en el siglo XVI, encontramos las primeras documentaciones de preciso $_{3}$ 'absolutamente necesario, indispensable' que no se refieren al cumplimiento de una orden legal dentro de un tiempo fijado, sino que preciso $_{3}$ aparece en combinación con lexemas de tipo necesidad, necesario y urgente:

(143) presuponiendo que su presencia podrá hacer gran bien á toda la república cristiana, y nos sería gran placer hallarnos juntamente, si no fuese que el tiempo es tan corto y la necesidad tan urgente y precisa, que en caso que él insistiese en esta respuesta le diréis que por la importancia de la cosa en sí y por placer habremos de esta nueva; (Anónimo, fragmento, 1532 [Alonso de Santa Cruz, Crónica del Emperador Carlos V, c1550])

(144) en esa ciudad y su partido y prouincia estoy marauillado y con mucha rrazon sentido de la poca consideracion y rrespecto que en bra determinacion aveis tenido. no myrando a la gran justificacion en que venimos en condescender en los dichos dos medios siendo nras necesidades tan grandes como a todos son notorias y el rremedio dellas tan preciso y necesario que sin él en ninguna mana se puede sostener el estado de nra casarreal destos rreynos y a que por aliviarlos en quanto nos fue posible cuyo trauajo y fatiga sentimos [...]. (Anónimo, Cortes de Toledo 1538, 1538-1539)

(145) paga por razon del dicho derecho y diezmo es mucho menos: de lo cual todo viene mucho perjuicio y daño á nuestra Real Hacienda, y no embargante que atento esto y siendo como

32 Tampoco aparece en catalán (Grup Enciclopèdia Catalana, s.v. precís). 
son tan grandes y precisas nuestras necesidades por los gastos que se nos ofrescen cada dia para la defensa y sustentacion de estos Reinos que nos nescesitan ayudarnos y socorrernos de nuestra hacienda, pudiéramos con justificacion poner y mandar desde luego que [...]. («Traslado de la Carta que se dio para que Juan de Peñalosa y los Factores que están en los puertos y Aduanas donde se cobran los derechos de los diezmos de la mar [...]», 1562)

La aparición del significado 'necesario, indispensable' en español y portugués (Machado 1967, s.v. preciso) parece ser simultánea, ya que para ambas lenguas este uso se data en el siglo XVI y los ejemplos citados confirman que se origina en el discurso jurídico.

$\mathrm{Preciso}_{3}$ 'necesario, indispensable' forma, además, una construcción copulativa frecuente que expresa una necesidad absoluta. En el $\mathrm{CDH}$, la secuencia [ser (lema) + preciso + que] o [ser (lema) + preciso + verbo en infinitivo] aparece alrededor de 1600 y se consolida en el siglo XVII:

(146) No es preciso que enfermen más de la mitad de los individuos de un pueblo para afirmar la existencia de una peste. Y es razón de poco momento, aunque parezca poderse sacar de Galeno, pensar ni decir que es necesario que dé y comprenda a muchos, y que por esto deba entenderse la mayor parte del pueblo. (Luis Mercado, Libro de la peste, 1599)

(147) Y porque el excesso y punto a que han llegado los gastos que se hazen en los casamientos, y obligaciones que en ellos se han introduzido, se consideran por carga, y grauamen de los vassallos: pues consumen las haziendas, y empeñan las casas, y ayudan a la despoblacion deste Reyno: pues por ser tan grandes, es preciso que lo ayan de ser las dotes, con lo qual se vienen a impedir: pues ni los hombres se atreuen, ni pueden entrar con tantas cargas en el estado del matrimonio, considerando, que no las han de poder sustentar con la hazienda que tienen, ni las mugeres se hallan con bastantes dotes para poderlas suplir; (Anónimo, Capitulos de reformacion, que su magestad se sirve de mandar guardar por esta ley, para el gouierno del Reyno, 1623)

La colocación es preciso que equivale al verbo precisar $_{3}$ 'necesitar urgentemente', que aparece a inicios del siglo XVI:

(148) el honrado pasajero haga provisión de algún barril o bota o cuero de muy buen vino blanco, el cual si posible fuere sea añejo, blando y oloroso; porque después, al tiempo del revesar, precisará tener allí más una gota que en otro tiempo una cuba. (Fray Antonio de Guevara, Arte de marear, 1539)

En cuanto al adverbio precisamente 3 'necesariamente, indispensablemente', esto uso aparece en combinación con adjetivos como necesario o forzoso, en la segunda mitad del siglo XVI:

(149) vuestra Majestad lo ha proseguido y va siempre aumentando, con idóneos ministros espirituales y temporales de todas profesiones y facultades para cuya administración y 
ejecución, como sea tan precisamente necesaria la buena y acertada navegación de tan grandes y espaciosos mares, en tantas y tan diferentes y diversas costas de tierras y regiones, en que tantos y tan grandes y diversos peligros suelen y pueden suceder [...]. (Juan de Escalante de Mendoza, Itinerario de navegación de los mares y tierras occidentales, 1575)

(150) demás cosas necessarias hasta, como dizen, ponerla de vergas en alto; y de sus officiales, orden de governarla y cómo deve estar para el uso de guerra o merchancía; y de las partes nescessarias y precissamente forçosas que se han de entender para su buena administración; assí como saber entender la esphera y aguja de marear, el quadrante del Sol, al astrolabio y ballestilla [...]. (Diego García de Palacio, Instrución náuthica para el buen uso y regimiento de las naos, su traça y gobierno, 1587)

(151) Yo, señora, precisamente te é de dexar mañana, ausentándome; y tú, forçosamente, as de quedarte sola, más encendida, más ayrada y enojada conmigo; pues más quiero perder este contento momentáneo que tu gracia y amor. (Gonzalo de Céspedes y Meneses, Varia fortuna del soldado Píndaro, 1626)

A veces, precisamente necesario aparece en el contexto de un modo de vida ascético que se limita a lo más indispensable y a lo mínimamente necesario:

(152) Estauase de rodillas delante del, perpetuamente, quanto le daua de lugar la obediencia. La cama no era para estar en ella, lo que precisamente es necessario. (Fray José Sigüenza, Segunda parte de la Historia de la Orden de San Jerónimo, 1600)

En nuestra muestra base del siglo XX, ya no aparece precisamente ${ }_{3}$ 'necesariamente' y, de hecho, se califica de «anticuado» en el diccionario de Santos Río (2003).

Por último, se crea también una locución adverbial: de preciso 'necesaria, forzosamente'. Sin embargo, su uso es muy marginal (no aparece en los diccionarios) y se limita al significado de preciso $_{3}$ :

(153) Supongamos te han pedido el tres de Oros, contarás por el primer naype de la primera hilera, y dirás (entre sí) cinco de Bastos, y cinco de memoria, componen diez, con que el segundo naype de la primera hilera, naturalmente será la Sota de Oros: luego contarás diez de Oros, y los cinco de memoria componen quince; quitando doce, quedan tres; de preciso el tercer naype ha de ser el tres de Copas: luego sabido que los terceros naypes de las quatro hileras, son los treses, dirás (baxito) despues de Copas se siguen Espadas, despues Bastos, y después Oros: (Pablo Minguet e Yrol, Engaños a ojos vistas y diversión de trabajos mundanos, 1733)

(154) Pero es el caso que soy poseedor de grandes verdades que me han sido reveladas en mi sueño por nube o llama o no sé yo qué (por la gracia divina) y solo a usted, señor comisario, puedo transmitírselas, para lo cual necesito de preciso verme libre de éstas mis prisiones materiales que me tienen aherrojado. Haga algo por mí, señor comisario. No soy un criminal ni un loco, como pretenden. (Eduardo Mendoza, La verdad sobre el caso Savolta, 1975) 


\subsubsection{Preciso $_{4}$ 'inminente'}

Alonso (1958, s.v. preciso) menciona un cuarto significado: en el siglo XVII, preciso se usa con el significado 'inminente'. Este uso se documenta también esporádicamente en la muestra base. Los ejemplos se limitan a los siglos XVI y XVII y al género literario elaborado. En ellos, preciso se atribuye a un suceso amenazante que está a punto de ocurrir:

(155) Pues ya el preciso hado y dura suerte me amenazan con áspera caída y forzoso he de ver un mal tan fuerte, un mal como es de vos verme partida, dejadme llorar antes de mi muerte [...]. (Alonso de Ercilla, La Araucana, primera parte, 1569)

(156) Agora, madre Mitilene, advierte, pues vengo al agua como cierva herida, con qué velocidad voy a la muerte, huyendo de los brazos de la vida; dime si la precisa fatal suerte esta sentencia tiene definida, y si podré esperar, o será en vano, del sabio tiempo la divina mano. (Lope de Vega Carpio, La hermosura de Angélica, 1602-1604)

(157) Leonor Pues ¿hay más de que le engañes a tu padre, y que este Lope que por hermano te traen, con la piel del otro hermano hoy la bendición le gane, como el otro lo hizo marras? D. - Inés ¿Cómo ha de ser eso fácil? Leonor: Mas él viene. D. - Inés: Sin mí estoy entre dos precisos males. (Agustín Moreto, El parecido en la Corte, 1652)

Este significado no se registra en ningún diccionario consultado en el NTLLE y tampoco se documenta en precisamente. Se trata, pues, de una innovación semántica de preciso en el lenguaje literario, que no cuaja en la lengua común y acaba por desaparecer. A nuestro modo de ver, el significado 'inminente' deriva del significado 'obligatorio, forzoso': cuando preciso se atribuye a sustantivos como hado, suerte o mal, se refiere a una fuerza sobrehumana que rige los sucesos fatales. Ya que no hay manera de escaparse de ello, forzosamente van a ocurrir. Preciso $_{4}$ 'inminente' solo aparece en relación con sucesos negativos, amenazan- 
tes. Así, este uso parece retomar y reactivar - de manera metafórica - también el uso latino de preciso ‘abrupto, escarpado', que también puede conllevar connotaciones de un peligro amenazante.

\subsubsection{Sintesis: la diacronía de preciso/precisamente}

El significado etimológico base de PRAECĪsus ‘recortado, abreviado’ se pierde en español, pero la familia léxica de los cultismos preciso, precisamente, precisar y precisión desarrolla una serie de significados derivados de este concepto, que se diferencian entre sí por su contexto de uso:

a) El significado 'breve, conciso' en cuanto al lenguaje ya existía en latín y se retoma en español, principalmente en el adjetivo conciso. En cambio, preciso y precisamente desarrollan un significado nuevo en relación con el lenguaje: 'exacto, claro, nítido’ ( preciso $_{1} /$ precisamente $_{1}$ ). Además, preciso $_{1}$,

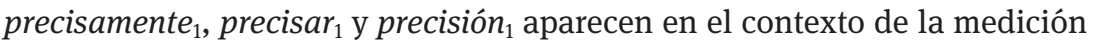
del tiempo y espacio con instrumentos científicos exactos. Esta innovación semántica - que no remite al latín- es paralela en francés y en español (siglo XVI).

b) El adjetivo francés précis se usaba ya desde el siglo XIV con el significado administrativo 'fijo, formal y determinado', igual que el adverbio précisement. Este significado se presta al español a finales del siglo XV y aparece exclusivamente en el discurso jurídico y notarial. Hace referencia, por ejemplo, al cumplimiento de una orden legal dentro de un plazo fijado. El uso de preciso $_{2}$, precisamente $_{2}$ y precisar $_{2}$ se limita, pues, a un discurso muy concreto y solo se mantiene marginalmente en español.

c) Preciso $_{3}$, precisamente $_{3}$ y precisar $_{3}$ expresan una necesidad absoluta e indispensable. Este uso surge por cambio semántico a través del componente semántico 'obligatorio, indispensable', inherente al uso jurídico (significado 2). Esta innovación se da exclusivamente en español y en portugués y data del siglo XVI.

d) Preciso $_{4}$ 'inminente', que hace referencia a un suceso negativo que está a punto de ocurrir, se documenta solo esporádicamente en la lengua literaria y se ha perdido actualmente.

Ahora bien, estas innovaciones no se observan de manera sucesiva en el corpus, dado que todos los significados se documentan ya en la primera mitad del siglo XVI (con algunas documentaciones esporádicas anteriores). En comparación con justo, cuya evolución semántica 'justo, según las leyes (de Dios)' > 'equilibrado, correcto' > 'exacto' se prolonga a lo largo de varios siglos (véase apartado 
3.1.3), las innovaciones semánticas de preciso - aunque se puedan reconstruir en cadena- son simultáneas. Por lo tanto, consideramos muy probable que haya calcos del francés, ya que précis y précisement aparecen ya en el XIV. Asimismo, en catalán, la aparición de precís y precisament es anterior al español: precís y precisament ya aparecen en la segunda mitad del siglo XIV (Grup Enciclopèdia Catalana, s.v. precís, precisament).

Los Gráficos 4 y 5 muestran la dispersión diacrónica de los tres significados principales de preciso y precisamente en nuestra muestra base. Si comparamos las primeras ocurrencias del adverbio precisamente con las del adjetivo preciso, llama la atención que el adverbio irrumpe con mayor frecuencia que el adjetivo: durante el siglo XIV y la primera mitad del siglo XV, hay más ocurrencias de precisamente que de preciso:

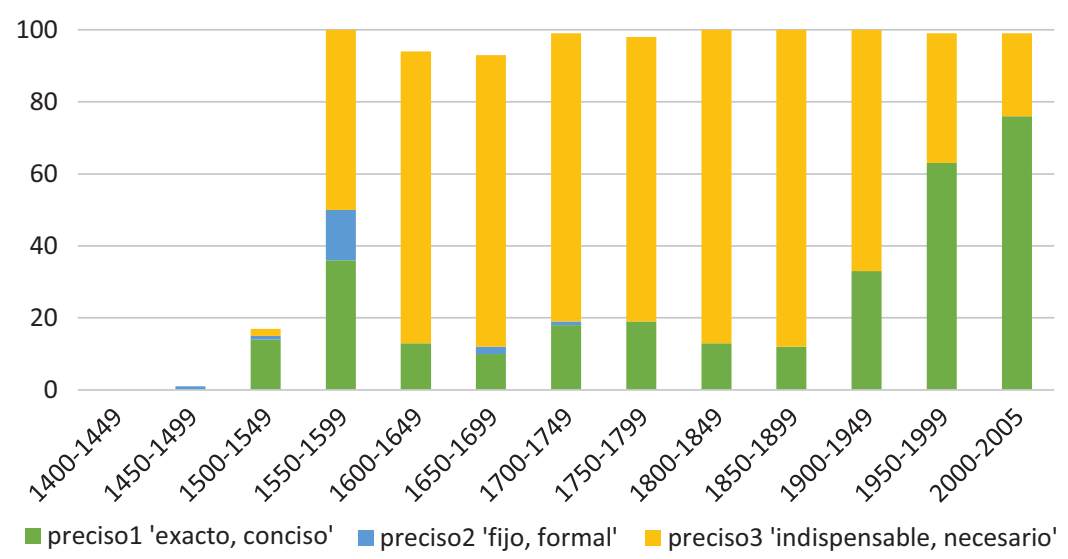

Gráfico 4: Dispersión diacrónica de los significados de preciso en la muestra (máx. 100 ejemplos por medio siglo).

En este sentido, los datos no permiten reconstruir una creación nueva, produc-

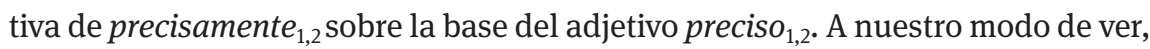
el hecho de que el adverbio derivado aparece y cuaja antes que su adjetivo base también indica que se trata de un préstamo tomado ya como unidad lexicalizada, probablemente del francés précisement. Solamente el tercer significado ('necesidad absoluta'), que sí es una innovación propia del español y portugués, se extiende primero en preciso $_{3}$ 'indispensable, necesario, obligatorio’ y, algo más tarde, en precisamente 3 . Este tercer significado es el más frecuente del adjetivo hasta mediados del siglo XX. En cambio, en el adverbio predomina desde el inicio el significado precisamente $_{1}$ 'exactamente', que se convierte en el único signifi- 


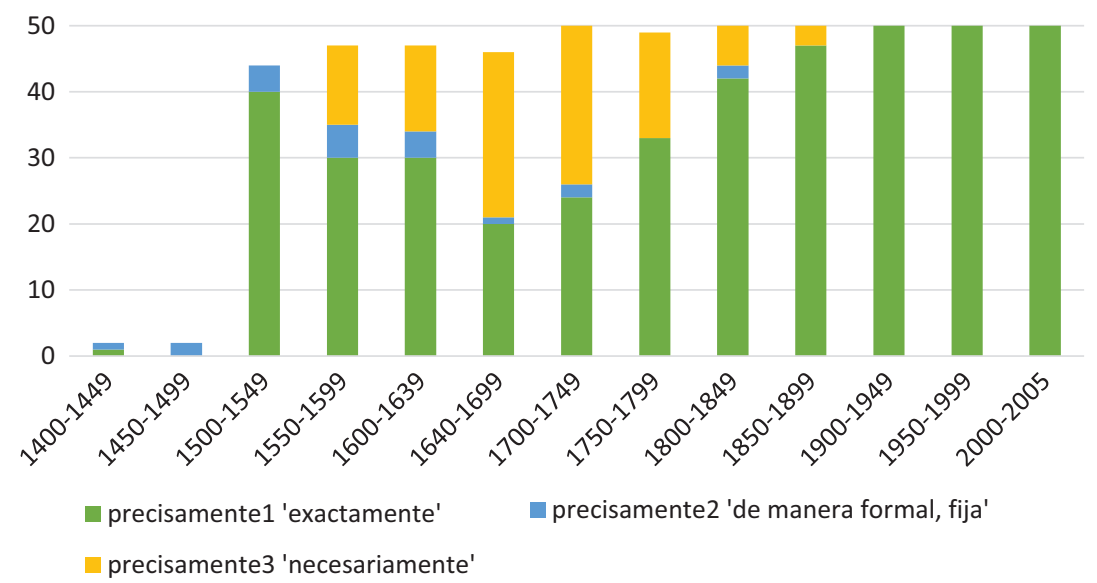

Gráfico 5: Dispersión diacrónica de los significados de precisamente en la muestra base (máx. 50 ejemplos por medio siglo).

cado en el siglo XX. Los diversos usos pragmáticos de precisamente como adverbio enfático, por ejemplo, de coincidencia, derivan de este significado conceptual base (véase capítulo 5).

El uso jurídico de 'formal, fijo, determinado' está presente desde los primeros ejemplos tanto en el adjetivo como en el adverbio. Este segundo significado es el que sirve de puente semántico entre el primer significado 'exacto' y el tercero ('necesario'), pero es bastante minoritario y también cae en desuso. Tanto preciso $_{2}$ como precisamente ${ }_{2}$ son usos muy marginales, probablemente porque se limitan al discurso jurídico.

Por último, llama la atención la poca variación en el paradigma morfológico de los adverbios derivados de la base léxica preciso en comparación con la variación observada en justo/justamente/al justo (véase 3.1.7). El uso de preciso ${ }_{1}$ 'exacto' como adverbio corto es muy marginal y solo se documenta en los siglos XVI y XX. El estatus culto de preciso se confirma también por documentaciones esporádicas del adverbio latinizante precise (siglo XV). Asimismo, la locución adverbial de preciso $_{3}$ 'necesariamente', que data del siglo XVIII, no parece haber cuajado. Semánticamente, el adverbio corto preciso $_{1}$ y la locución adverbial de preciso $_{3}$ no coinciden. Ambos son muy escasos y no pasan de ser fenómenos marginales. Al parecer, el préstamo culto preciso no acaba cuajando en la lengua hablada coloquial (véase más adelante, 4.1.2 sobre la baja frecuencia de preciso en la lengua hablada actual) en la misma medida que justo ${ }_{2}$ 'exacto', que también parte de un préstamo culto, pero acaba por popularizarse. 


\subsection{Exacto y exactamente}

La familia léxica constituida por el adjetivo exacto, el adverbio exactamente y el sustantivo exactitud comparte un mismo significado base que aparece en varios contextos de uso. Por un lado, exacto significa 'rigurosamente cierto o correcto' (DLE 2014, s.v. exacto), esto es, 'no aproximado, sino medido y calculado o expresado con todo rigor' (Moliner 1998, s.v. exacto). En este sentido, se usa frecuentemente en el contexto de números:

Un cálculo exacto. La hora exacta. La cinta tenía cuatro metros exactos. (Moliner 1998, s.v. exacto)

La testigo hizo un relato exacto de los hechos. (CLAVE 1999, s.v. exacto)

Este es también el significado subyacente a la construcción [ser (lema)+ exacto $+q u e]$ :

«Es exacto: equivale a verdad: No es exacto que yo estuviera alli.» (Moliner 1998, s.v. exacto)

Por otro lado, cuando se refiere a personas o acciones ejercidas por personas, exacto significa 'tal como está mandado o es obligado, como se pide; sin ningún cambio u omisión’:

El cumplimiento exacto de sus órdenes. Un exacto cumplidor de su deber. (Moliner 1998, s.v. exacto)

Por último, en referencia a la imagen física de cosas o personas, significa 'igual, o que se asemeja en un grado muy alto a algo o alguien que es tomado como modelo':

Copia exacta. Retrato exacto. Eres exacta a tu madre. (DLE 2014, s.v. exacto)

Los significados de exactamente 'con exactitud' son plenamente transparentes al corresponderse con los de exacto. Por eso, Moliner (1998, s.v. exactamente) escribe simplemente: «derivado de significado deducible de exacto». No encontramos ejemplos ni definiciones más detalladas en ninguno de los diccionarios consultados. Asimismo, exactitud se define como 'cualidad de exacto' (DLE 2014, s.v. exactitud) y se corresponde, pues, con el adjetivo base.

En cuanto a exacto como adverbio corto, solo encontramos mencionado este uso en algunos diccionarios que clasifican exacto como adverbio afirmativo (CLAVE 1999; DLE 2014, s.v. exacto). Sin embargo, tal y como observamos también en el caso de cabal (véase apartado 3.2.2), optamos por no clasificar este uso como adverbial, ya que creemos que el marcador de afirmación se basa en el uso adjetival de exacto (véase capítulo 6, y especialmente el apartado 6.5.2 para el 
origen de este marcador de afirmación). Queda, pues, por analizar si se desarrolla un uso de exacto, por ejemplo, como adverbio de modo.

\subsubsection{Origen léxico (EXĀCTUS en latín) y préstamo culto}

En latín, EXĀCTUS es el participio de EXIGERE 'hacer pagar, cobrar', 'exigir, reclamar', con lo cual el español exacto está etimológicamente relacionado con el verbo exigir (Corominas/Pascual 1997, s.v. exigir). El verbo EXIGO, -ĒGĪ, -ĀCTUM, -ERE está compuesto por EX y AGERE 'hacer' (TLL 2009, s.v. EXIGo) y significa 'echar fuera', 'exigir’, 'hacer pagar', 'reclamar', 'pedir', 'apreciar', 'examinar' y 'acabar' (de Miguel [1867] 2000, s.v. EXIGO). Así, por ejemplo, Ovidio escribió HOC OPUS EXEGI (TLL 2009, s.v. EXIGo), es decir, 'he terminado esta obra'. El participio del pasado EXĀCTUS, -A, -UM se usa ya en latín como adjetivo (TLL 2009, s.v. EXIGo), con el significado 'cumplido, perfecto, absoluto, concluido, bien trabajado’ (de Miguel [1867] 2000, s.v. EXĀCTUS; Corominas/Pascual 1997, s.v. exigir). Por ejemplo, se emplea este adjetivo para calificar obras artísticas (TLL 2009, s.v. EXIGO). En este sentido, la valoración de 'perfecto' deriva de la idea de que una obra está terminada, concluida y cumplida.

Además, EXĀCTUS califica a personas 'perfectas’ y ‘egregias' (es decir, 'ilustres'), como, por ejemplo, en EXACTISsimo viRo (Epístola de Plinio) (TLL 2009, s.v. EXIGo). Aparte, significa también 'pesado con exactitud' (Segura Munguía 2013, s.v. EXĀCTUS), es decir, se usa con el significado 'moderado, cuidadosamente y diligentemente medido' en el contexto de números y especialmente pesos y medidas: «habent... omnes pondera atque mensuras exactas» (Scribonius Largus) (TLL 2009, s.v. EXIGO), 'tienen todos los pesos y las medidas exactas, moderadas'. Así, el adjetivo adquiere ya en latín el significado ‘exacto, preciso’ (Blánquez 2012, s.v. EXĀCTUS). Además, se usa en latín el adverbio EXĀCTĒ 'acurada, cuidadosa, diligentemente’ (de Miguel [1867] 2000, s.v. EXĀCTĒ; TLL 2009, s.v. EXIGO).

En español, exacto es un préstamo culto, como revela también su forma fonética. Según Corominas/Pascual (1997, s.v. exigir), suele pronunciarse como esacto, «aun entre la gente culta». Asimismo, la RAE anota en su Diccionario de Autoridades (1732, s.v. exacto): «Se pronuncia la $x$ como es». Al parecer, el español tomó prestado directamente el adjetivo lexicalizado EXĀCTUS 'perfecto, concluido, diligentemente medido', ya que, en la actualidad, exacto no mantiene una relación transparente con el verbo exigir. Como los significados actuales de exacto ya estaban presentes en el latín EXĀCTUS, no se observan en español cambios semánticos que den lugar a significados nuevos (al contrario, pues, de justo, cabal y preciso), sino que se trata de nuevos matices de uso que surgen del significado base que EXĀCTUS tenía en latín.

Según Alonso (1958, s.v. exactamente, exacto), tanto exacto 'puntual, fiel y cabal' como exactamente 'con exactitud' aparecen en el siglo XVII. Las primeras entradas 
de exacto en los diccionarios del NTLLE son de principios del siglo XVII, como, por ejemplo, en el de Vittori (1609), quien define su significado como 'correcto, entero'. Asimismo, Corominas/Pascual (1997, s.v. exigir) fechan exacto a inicios del siglo XVII. Todavía no aparece en el Tesoro de la lengua castellana o española de Covarrubias Orozco ([1611] 1995). Además, el verbo exigir es un préstamo culto del latín EXIGERE, que pasa al español en el siglo XVII, y el sustantivo exactitud, que deriva de exacto, aparece en el siglo XVIII (Corominas/Pascual 1997, s.v. exigir).

Sin embargo, igual que en el caso de justo/justamente, preciso/precisamente y cabal/cabalmente, el CDH nos obliga a revisar las fechas mencionadas en las obras lexicográficas citadas (Alonso 1958; Corominas/Pascual 1997). En el CDH, exacto aparece esporádicamente en la primera mitad del siglo XVI y exactamente en la segunda mitad del mismo siglo, aunque ambos se consolidan y expanden su uso en el siglo XVII. Asimismo, en francés, exact y exactement son préstamos cultos ya del siglo XVI (DHLF 2000, s.v. exact).

\subsubsection{Exacto /exactamente $_{1}$ 'cabal, puntual, riguroso, cierto, correcto'}

En el siglo XVI, exacto y exactamente aparecen de manera esporádica en textos matemáticos. Su significado es 'no aproximado, sino medido y calculado o expresado con todo rigor', es decir, retoman un valor que ya se usaba en latín:

(158) Mas no puede esto ser preciso porque la quantidad de los ángulos no se conosce sin la tabla de arcos y cuerdas, las quales como consta por el primero libro del Almagesto, no pueden ser exactas porque las más de las cuerdas son raízes sordas y sabidas por otras raízes sordas. Por lo qual obrando por aquel modo, no hallaremos la verdadera quantidad de cada uno de los dos lados [...]. (Pedro Núñez, Libro de Álgebra en Aritmética y Geometría, 1567)

(159) aunque es verdad que todo este globo o máchina del mundo, compuesta de tierra y agua hazen, y constituyen un cuerpo tan ygual y exactamente redondo que, en qualquier parte de la tierra o del mar que el hombre se ponga, dista ygualmente del cielo, que es gran indicio, como dizen los astrólogos, de ser toda esta bola [...]. (Juan de Cárdenas, Primera parte de los problemas y secretos maravillosos de las Indias, 1591)

En esta misma línea, se aplican a instrumentos científicos que funcionan rigurosamente:

(160) Así de las visiones y los tactos que como forma sustancial produce, se ven los instrumentos más exactos; (Lope de Vega Carpio, La Circe con otras rimas y prosas, 1624) 
(161) Formarase después un Pitipié muy exacto conforme la capacidad del lugar. Començando luego la descripción desde uno de los puntos conocidos de la primera planta, se observará todo lo dicho en la mina, midiendo exactamente las distancias de una estación a otra con la cadenilla, y observando la anchura de las calles, y Plaças [...]. (José Zaragoza, Fábrica y uso de varios instrumentos matemáticos, 1675)

Por otro lado, se documenta ya en el siglo XVI el uso de 'fiel, rigurosamente cierto o correcto, entero' en relación a la descripción de algo en palabras correctas y ciertas. El significado ‘rigurosa y matemáticamente exacto’ se extiende, pues, a un nuevo contexto de uso:

(162) pueblos de españoles en asiento de minas o en rancherías o en estancias o chácaras, o ingenios, pueblos de indios cabeceras y sujetos. De todo lo cual mandamos se haga descripción muy exacta y precisa en la forma siguiente: [...]

cuenta y razón con todas y cada una de las que son de su diócesis y arciprestazgo, parroquia y doctrina y que los pastores las conozcan y ellas a sus pastores, ordenamos y mandamos que la más exacta descripción, averiguación y relación de todas cuantas mandamos hacer sea de las ánimas que están a cargo de cada arzobispo, obispo y prelado y de cada arcipreste y de cada cura y de cada ministro [...]. (Anónimo, «Ordenanzas para la formación del libro de las descripciones de Indias», 1573)

(163) pretendo decir en este libro algo de lo mucho que hay digno de historia en Indias, cerca de los metales, y plantas y animales que son más propriamente de aquellas partes; y porque tratar esto exactamente sería obra muy grande y que requiere mayor conocimiento que el mío y mucha más desocupación de la que tengo, digo que solamente pienso tratar sucintamente algunas cosas [...]. (José de Acosta, Historia natural y moral de las Indias, 1590)

Este uso corresponde a la definición de «no faltar un ápice a lo que se dice o se hace; el que hace una relación enteramente veraz y sin omitir la menor circunstancia en ella» (Zerolo 1895, s.v. exacto). Lo que se describe es tanto 'cierto, verídico, positivo, conforme la verdad' como 'cabal, completo' (Domínguez 1853, s.v. exacto). En este sentido, una descripción es exacta cuando es lo más fiel posible a la realidad y lo más detallada posible. Este uso también remonta a EXĀCTUS en latín, que calificaba a obras 'perfectas, acabadas, terminadas'.

Como muestran los siguientes ejemplos, exacto frecuentemente se combina con los lexemas diligente/diligencia, puntual/puntualidad y rigor:

(164) otros escriptores a causa de haber escripto lo que no vieron y mal digerir lo que habían oído, quisieron referir [aquello] a lo que se hallaron presentes y lo que con exacta y suma diligencia de lo que antes de su tiempo había pasado supieron, como fue dicho.

$[. .$.$] los libros que contienen daño y perjuicio [...] que de nuevo sus auctores quisieren$ poner en público, por personas doctas en aquellas materias y amigas de la virtud sean con exactísima indagación examinados; porque, como siempre, lo que los componen pretendan conseguir, o para sí o para sus obras, favor y auctoridad [...]. (Fray Bartolomé de las Casas, Historia de las Indias, 1527-1561) 
(165) Como se peca en la destemplanza de los premios y mercedes, se peca también en el exceso de los castigos. Una exacta puntualidad y rigor más es de Ministro de justicia que de príncipe. En aquél no hay arbitrio; éste tiene las llaves de las leyes. No es justicia la que excede, [...]. (Diego de Fajardo Saavedra, Empresas políticas, 1640-1642)

Exacto y exactamente se usan predominantemente en el discurso científico. Así, exacto también califica a mapas hechos de manera diligente, rigurosa y lo más fiel a la realidad posible:

(166) También los mapas más exactos ponen «Río Marañón» allá al principio de aquel que baxa de el Cuzco, de el cual consta que, juntándose con otro de igual grandeza y después con otros menores, le han navegado muchos españoles [...]. (Manuel Rodríguez, El Marañón y Amazonas. Historia de los descubrimientos, 1684)

Originariamente, exacto se atribuye a sustantivos más bien concretos, que hacen referencia al producto de un esfuerzo científico o artístico riguroso: cálculos, dibujos de mapas, descripciones de la realidad, etc. Es decir, califican a alguna obra 'acabada y perfecta'. En el siglo XVII, exacto y exactamente extienden su uso hacia contextos más abstractos y se usan, por ejemplo, para la cognición humana en general. En el siguiente ejemplo, saber exactamente 'estricta, rigurosa, perfecta, absolutamente' se opone a 'superficial, aproximado, general':

(167) Cerca de las demás facultades, ya que no se sepan exactamente, a lo menos hase de tener alguna noticia general de los términos dellas, para hablar con propiedad cuando se traen doctrina o ejemplos dellas en el púlpito y no causar risa a los oyentes [...]. (Francisco Terrones del Caño, Instrucción de predicadores, 1605)

En la misma línea del discurso científico, aparece en la segunda mitad del siglo XVIII la colocación ciencias exactas:

(168) Aunque sean muchos los cursos matemáticos publicados hasta aquí, carecemos todavía de uno completo y bien organizado. Es fácil la enumeración de las materias que comprende las ciencias exactas; pero un curso completo de esta naturaleza, requiere el estudio de algunos hombres hábiles, que bajo de un buen plan, se destinen a escribirle con la precisión que exigen estos tratados. (Pedro Rodríguez Campomanes, «Carta al Marqués de Pombal», 1772)

El valor 'cierto, verdadero' es también la base de la expresión [ser + exacto + que], que aparece más tarde, a mediados del siglo XIX:

(169) Tampoco es exacto que el artículo declare que el gobierno es tiránico. (Emilio Castelar, «Discurso pronunciado por Don Emilio Castelar ante el jurado, en defensa del periódico «La Soberanía Nacional, acusada por un artículo que refería los sucesos que tuvieron lugar con ocasión de la ley de Milicia Nacional», 1854, Discursos políticos y literarios) 
(170) La desesperación puede apoderarse de él y producir la demencia ó el suicidio; porque aunque no sea exacto que el hombre se acostumbra á todo, es cierto que se acostumbra á muchas cosas; que en las impresiones físicas y morales la capacidad de sufrir crece sufriendo [...]. (Concepción Arenal, Estudios penitenciarios, 1877)

\subsubsection{Exacto $_{2} /$ exactamente $_{2}$ 'igual, semejante’}

La variante 'igual, o que se asemeja en un grado muy alto a algo o alguien que es tomado como modelo' (DLE 2014, s.v. exacto) es algo posterior. Se desarrolla a partir de la idea de una correspondencia, imitación o semejanza exacta, estricta y rigurosa entre dos cosas. Como se observa en estos ejemplos, este significado surge antes en el adverbio exactamente (siglo XVII):

(171) Mas como era obra para Dios, esto hizo y otras cosas mayores podía su fe. Imitó curiosa y exactamente don Filipe en esta su fábrica lo que muestra la descripción que hace la sabiduría de la Santa Jerusalén, procurando se hallase tanta armonía, concierto y correspondencia, [...]. (Luis Cabrera de Córdoba, Historia de Felipe II, rey de España, 1619)

(172) Cumplirá con las leyes de copia la que se parezca exactamente a su original; mas si éste es feo, también lo será el retrato. (Gonzalo Pérez de Ledesma, Censura de la elocuencia, 1648)

Este significado radica, pues, en el uso de exactamente 'rigurosamente' como adverbio de modo de verbos como imitar y parecer. En estos ejemplos, se copia de manera rigurosa un original, por lo tanto, también estamos ante productos de un esfuerzo científico o artístico. La obra 'perfecta y acabada' consiste en una copia semejante al original e implica una comparación entre el original y la copia. Exactamente califica de rigurosa la acción de copiar o imitar.

A continuación, en el siglo XVIII, el adjetivo base exacto adopta el nuevo significado 'igual, semejante' en cuanto a la comparación entre un original y su copia. Sobre todo, este uso indica semejanza y parecido en cuanto al aspecto físico, o sea, es visualmente perceptible. Por ejemplo, un retrato o una copia reproduce con exactitud el original:

(173) Si V. Ema. quisiera que de los cinqüenta pliegos se saque ahí alguna copia para comunicarlos á algun Erudíto, quisiera yo que V. Ema. se quedase con mi original, pues hay pocas copias exâctas. Por lo mismo no he querido remitir á V. Ema. copia alguna, sino el mismo, y el único original, ó autógrapho mio; (Fray Martín Sarmiento [Pedro José García y Balboa], Memorias para la Historia de la poesía y poetas españoles, 1745) 
(174) Hemos disfrazado, no solo el nombre, sino hasta el pueblo de este individuo, por ser exacto retrato hasta en los más mínimos pormenores de una persona que murió ha pocos años, los cuales todos hemos recogido con la mayor y más esmerada actitud [...]. (Fernán Caballero [Cecilia Böhl de Faber], Clemencia, 1852)

(175) Ahora Julio lo palpaba, sí, era aquél el retrato de su querida, igual, exacto; esos ojos eran los que en los suyos se habían mirado, pero también los que a la hora del placer supremo entrecerrábanse mirando hacia la altura; ésos, los labios que le juraron idolatrarlo [...]. (Federico Gamboa, Suprema Ley, 1896)

En los ejemplos que acabamos de citar, la semejanza exacta entre el original y la copia es el resultado de un esfuerzo científico-artístico obviamente intencionado. Desde este origen concreto, exacto 'igual, semejante' se extiende a comparaciones que no son producto intencionado de una imitación:

(176) Pero lo más ordinario es, que se hace mysterio de lo que no le tiene, y qualquiera leve analogía se concibe, o pondera, como si fuesse una exacta semejanza. (Benito Jerónimo Feijoo, Cartas eruditas y curiosas I, 1742)

(177) con esto y un abrazo se despidió el buen padre, que en la realidad cada uno de por sí eran todos de admirable rato, políticos, atentos y de una correspondencia exacta. Pero en comunidad eran otros hombres, como se ha visto en los procesos públicos que se les formaron para su expulsión. (Concolorcorvo [Alonso Carrió de la Vandera], El Lazarillo de ciegos caminantes, 1775)

Por su parte, el adverbio exactamente, que originariamente era un adverbio de modo que calificaba de rigurosa a la acción de copiar, extiende su uso y aparece con frecuencia como adverbio de foco (véase apartado 5.3.1) en estructuras comparativas, enfatizando que una cosa se parece visualmente a otra:

(178) Los coches que vi en el paseo eran exactamente como los que se ven en el Prado de Madrid, ni mejores ni peores; pero aquí hay más luxo en materia de criados, no hay señorcillo que no lleve su par de lacayos [...]. (Leandro Fernández de Moratín, Viaje a Italia, 1793-1797)

(179) En la tabla de mármol que sirve de balaústre se ven, entre otras labores de capricho, dos cruces floreadas, exactamente iguales a las que pintan las Ordenes de Calatrava y Alcántara. (Gaspar Melchor de Jovellanos, «Diario de 1793», 1793)

La combinación de exacto con la preposición $a$ aparece a finales del siglo XIX. Esta colocación parece seguir el modelo de igual a y parecido a (según la búsqueda en el CDH, ambas colocaciones ya se usaban en el medievo):

(180) no se extrañe después que la actividad humana deje de dar sus frutos, no se extrañe que las teorías de la ciencia no pasen a la esfera de la práctica y permanezcan siempre, 
exactas a la verdad, pero también estériles e infecundas, en las regiones especulativas. (Mariano Carreras y González, Tratado didáctico de economía y política, 1881)

(181) En varias descripciones de ciudades marroquíes antiguas y modernas, se hace notar la disposición de sus edificios, casi exacta á la que tenían en Granada. (Francisco de Paula Valladar, Fiestas del Corpus en Granada, 1886)

Además, esta preposición es la que corresponde a los verbos parecer(se) a, asemejar(se) a y corresponder $a$.

Ya que este uso enlaza de manera transparente con el significado base de 'preciso, correcto' (apartado anterior), no creemos que se trate de un cambio semántico. No estamos ante una polisemia de exacto $_{1}$ frente a exacto ${ }_{2}$, sino ante dos variantes contextuales de un mismo significado base: en el contexto de comparaciones, exacto y exactamente adquieren el matiz 'igual, semejante'. Aun así, destacamos este uso por su alta frecuencia en la muestra base y por los usos específicos que desarrollan tanto el adjetivo (exacto a) como el adverbio (véase más adelante, apartado 5.3.1, sobre el uso enfático de exactamente igual/exactamente lo mismo), y que no comparten con preciso/precisamente, cabal/cabalmente ni justo/justamente.

\subsubsection{Exacto $_{3} /$ exactamente $_{3}$ 'esmerado, diligente, escrupuloso'}

El significado 'esmerado, diligente' ya estaba presente en latín; por ejemplo, EXACTISSIMO VIRo (véase apartado 3.4.1). En español, se documenta a partir del siglo XVI y retoma, pues, directamente un uso del latín. A nuestro modo de ver, también enlaza con el significado base de exacto, dado que hace referencia a cumplir al pie de la letra una orden o a seguir rigurosamente una regla. Se cumple, pues, lo exigido de manera perfecta. Recordemos que la etimología de exacto es el verbo EXIGERE 'exigir'. Este tercer uso es otra variante contextual de exacto y exactamente, cuando se refieren al comportamiento de una persona y a su modo de actuar. Por metonimia, exacto no solo califica al resultado de una obra terminada y perfecta, sino también a la persona que la crea o que la lleva a cabo.

En el CDH, cuando exacto califica al comportamiento de una persona, aparece frecuentemente en el contexto de guardar una regla o norma:

(182) Tenían en gran reverencia y usaban y guardaban exactísima religión con sus difunctos y sepulturas y entierros, y ninguna injuria se les podía cometer ni que más sintiesen que tocarles a sus difunctos y violalles sus sepolturas. (Fray Bartolomé de las Casas, Apologética historia sumaria, 1527-1550) 
(183) El qual no desseava esta perfeción de la obediencia solamente en los de la Compañía, mas siempre que le pedían consejo personas de otras religiones de cómo y en qué avían de obedecer a sus superiores, los endereçava por estos mismos caminos y seguras sendas de verdadera obediencia. Y el mismo padre, que era maestro desta escuela de la perfeta y cumplida obediencia, la guardava s exactíssimamente. (Pedro de Ribadeneira, Vida de San Ignacio de Loyola, 1583)

(184) En los demás dias de las sesiones todos los sacerdotes dirán misa muy de mañana; y para ello, hallarán disposicion en la dicha nuestra Santa Iglesia Catedral y en las demas iglesias de nuestra jurisdiccion. Guardarán exacto silencio en las sesiones, sin inquietarse así cuando se estuvieren leyendo las Constituciones, como cuando ordenáremos ó avisáremos alguna cosa, para que así puedan percibir perfectamente los saludables preceptos que dieremos. (Anónimo, Constituciones sinodales de Venezuela hechas por don Diego de Baños y Sotomayor, 1687)

En los diccionarios consultados a través del NTLLE, este uso se define de la siguiente manera: 'puntual, esmerado, diligente' (DRAE 1726-1739, s.v. exacto), 'escrupuloso, puntual' (Terreros y Panda 1786-1788), 'puntualmente pronto en cumplir un deber, una palabra dada, una cita u orden recibida' (Domínguez 1853) $\mathrm{y}$ 'cuidadosa y diligentemente, con puntualidad y fidelidad' (DRAE 1726-1739, s.v. exactamente). Asimismo, Mez de Braidenbach (1670) traduce exacto al alemán como 'fleißig' y exactamente 'mit Fleiß' ('diligente, con empeño'). En el CDH, es un uso muy frecuente en el siglo XVII:

(185) Este día el Cabildo remitió a la Diputación vean las nóminas de los que asisten a Maitines y cómo asisten y dispongan el modo más conveniente para que se acuda a ellos sin que haya falta alguna y se cumpla exactamente con la obligación y ordenó que se llame al capellán mayor para saber cómo acude a la obligación que tiene de decir Vísperas [...]. (Anónimo, Documentos sobre música en la catedral de Sigüenza, 1600-1713)

(186) Tambien le tubieron muy grande los nuestros en el nombramiento que hiço el padre Prouinçial de Rector de nuestra cassa y colegio que fue, el Padre Diego de Bracamonte hombre exactissimo para tal cargo de grande oraçion y muy aprobado en prudençia que acompañandola con el modo afable y suaue que tenia en tratar con los próximos [...]. (Juan Anello Oliva, Historia del reino y provincias del Perú, 1631)

(187) Esta semana dieron las gracias á S.M., por la exacta justicia de los papeles de Roales, los PP. Prepósito y Rector de este colegio, Palma, Pacheco, Pedro Mudarra, Pimentel, Albornoz y Guevara; (Francisco de Vilches, «Carta», 1634)

Sin embargo, es un uso poco frecuente hoy en día y apenas se documenta en el corpus:

(188) Tanto se manifestó esta voluntad, que antes de la firma de los Acuerdos de Paz, el 16 de Enero de 1992, los dirigentes de los partidos se habían incorporado a la mesa de nego- 
ciaciones y en su exacto rol de intermediación hacia el Estado, canalizaron varios de los acuerdos de ambas partes, plasmándolos como normas constitucionales. (Félix Ulloa, El dinero y la democracia. Un caso de estudio, 2004)

\subsubsection{Exacto como adverbio corto}

De manera esporádica, exacto se documenta como adverbio corto con el significado 'exactamente'. Además de seis casos recogidos en la muestra base, encontramos algunos registros más en el $\mathrm{CDH}$ (nuclear y ampliado). Por un lado, exacto aparece como adverbio de modo en los siglos XVII y XVIII. Califica de 'diligente, escrupuloso al cumplir una orden' el modo de acción del verbo observar 'guardar y cumplir exactamente lo que se manda y ordena' (DLE 2014, s.v. observar):

(189) representar las Personas, como que al presente viven en la relación las costumbres que en este mundo vivieron, es el principal elogio de la Historia. Este canon observa el Padre Maestro tan exacto, que en sus Anales, no parece que oymos, sino que vemos nuestros ilustres Fundadores; (Fray Fernando de Valverde, fragmento, 1656 [Bernardo de Torres, Crónica Agustina, 1657])

(190) Pues muy bien supieron los Eclesiasticos en punto del precio de la Sal, deducir embebia este en sì el tributo; y siendo cierto, que lo mismo sucede en lo que ellos venden, por embeber en sì el de la decima de Alcavala, y quatro unos, como les es de provecho el silencio, lo observaron exacto; y todo esto facilmente se resuelve, dando en los bienes de possession de cada unos lo correspondiente à su consumpcion: (Francisco Máximo de Moya Torres y Velasco, Manifiesto universal de los males envejecidos que España padece, 1730)

Por otro lado, exacto (adverbio) también aparece como adverbio de modo en el contexto de la reproducción exacta de las palabras:

(191) Espero que lo recuerde bien, para contarlo exacto. Voy a tratar de reconstruir sus palabras. (Miguel Ángel Asturias, El Papa Verde, 1954)

Aparte, exacto 'igual, semejante' también funciona ocasionalmente como modificador de sintagmas u oraciones subordinadas de comparación:

(192) ¡Pobre querido! ¡Como para no entregarse a la bebida y no querer a nadie más! Claro, ustedes, Cristina, es distinto. Porque en realidad ya son exacto como un teatro profesional, porque cobran tanto como si fueran profesionales. (Ernesto Sábato, Sobre héroes y tumbas [Argentina], 1961) 
(193) Para él no hay duda de que es la mujer más bella del mundo, ahí con su pose de sexo en la cama y el kevorkian-15 entre las piernas, exacto como ella lo quería. Sin embargo, ni el kevorkian-15 ni ninguna otra cosa a mano pudo evitar la descomposición eventual. (Alexánder Obando Bolaños, El más violento paraíso [Costa Rica], 2001)

Como muestran estos ejemplos, el uso de exacto como adverbio corto en el español actual parece estar limitado diatópicamente al español americano, a pesar de que antiguamente también aparecía en el español peninsular. Además, exacto aparece como adverbio flexionado en el español americano del siglo XX:

(194) Al fin, cuando todo parecía más que inútil, di casi por accidente con el paradero de una segunda estatua: a mediados de enero - cumplidos exactos tres meses de búsquedavino a visitarme un viejo amigo. (Ignacio Padilla, Imposibilidad de los cuervos, 1994)

(195) Ella se escapaba de la enorme cama quejumbrosa y tal vez ya eterna; se alejaba de los ronquidos nunca interrumpidos, podía decirse, durante las exactas ocho horas de sueño, y dejaba abierta la habitación del niño para continuar oyéndolos y poder mezclar tranquilamente sus lágrimas con las del hijo. (Juan Carlos Onetti, Dejemos hablar al viento, 1979)

Igual que en el caso de justo flexionado (apartado 3.1.7.1), la interpretación de exacto en estos ejemplos es ambigua entre adjetival y adverbial. Por un lado, podría tratarse de adjetivos antepuestos, esto es, en una posición sintáctica marcada. Por otro lado, también es posible una interpretación adverbial, ya que es factible conmutar exactos/exactas por exactamente en estos ejemplos. En el siguiente ejemplo, exactos se antepone al artículo del sintagma nominal, por lo cual tendemos a interpretar su posición claramente como la de un adverbio y no la de un adjetivo:

(196) De haber hablado cuando calló, se hubiera ahorrado exactos los cinco años que la amnistía le borraba de una plumada. (Antonio Skármeta, El baile de la Victoria, 2003)

Al parecer, el uso adverbial de exacto es más frecuente que el uso adverbial de preciso, pero menos que el de justo (adverbio). Como veremos más adelante (apartado 4.1.2), exacto es mucho más habitual en la lengua hablada que preciso. En este sentido, el uso adverbial de exacto apunta hacia la coloquialización o popularización de este lexema de origen culto - como hemos postulado también para justo-.

En cuanto a una posible locución adverbial, no encontramos ninguna frase preposicional que englobe exacto ( ${ }^{\star}$ al exacto, ${ }^{\star}$ de exacto, * ${ }^{*}$ por exacto). Probablemente, no surgieron soluciones perifrásticas de este tipo porque el uso de las locuciones adverbiales preposicionales históricamente decayó y perdió importancia 
después del siglo XVI (Hummel 2019). La difusión y consolidación de exacto/exactamente en la lengua popular quizás era demasiado tardía para ese desarrollo.

\subsubsection{Síntesis: la diacronía de exacto/exactamente}

Los tres usos más frecuentes de exacto y exactamente son variantes contextuales, ya que la relación semántica con el concepto base de exactitud es perfectamente transparente. No se trata de significados independientes que surgen a través de cambios semánticos (como en el caso de justo, cabal y preciso), sino que, en todos ellos, la idea básica de 'riguroso, estricto, diligente, correcto' se encuentra en la correspondencia exacta entre dos cosas: entre una norma y su cumplimento (uso 3), entre una copia y el original (uso 2) y entre lo que se mide, calcula o dice y la realidad extralingüística (uso 1). Estas variantes contextuales derivan del latín EXĀCTUS 'perfecto, completo', que calificaba a obras terminadas y acabadas y también hacía referencia a la exactitud en medidas y pesos, así como a personas 'perfectas, esmeradas'.

Como muestran los Gráficos 6 y 7, el uso de exacto se difunde algo más rápidamente que el de exactamente.

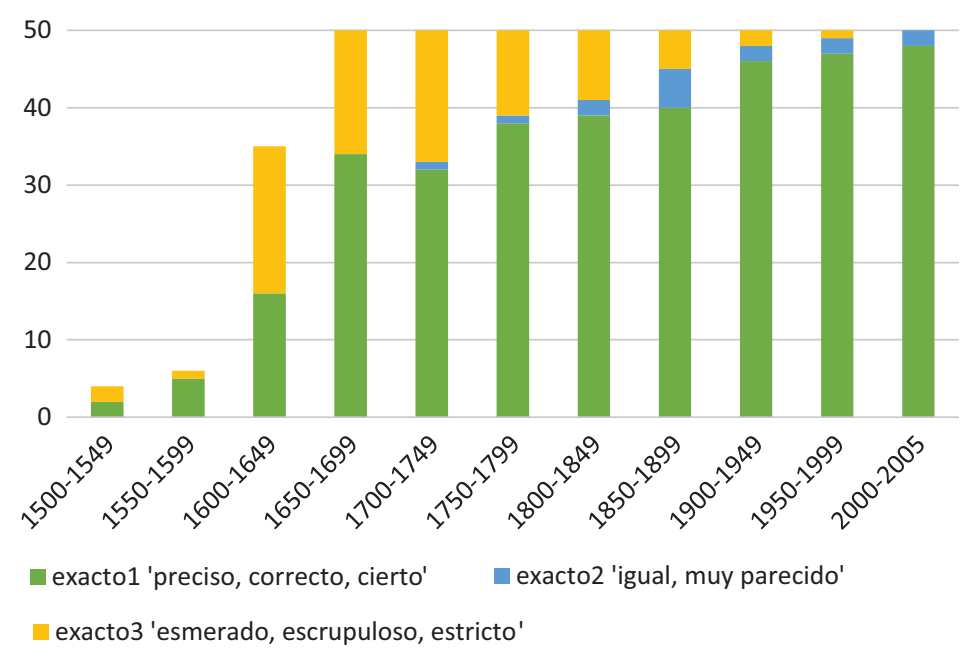

Gráfico 6: Dispersión diacrónica de exacto en la muestra base (máx. 50 ejemplos por medio siglo). 


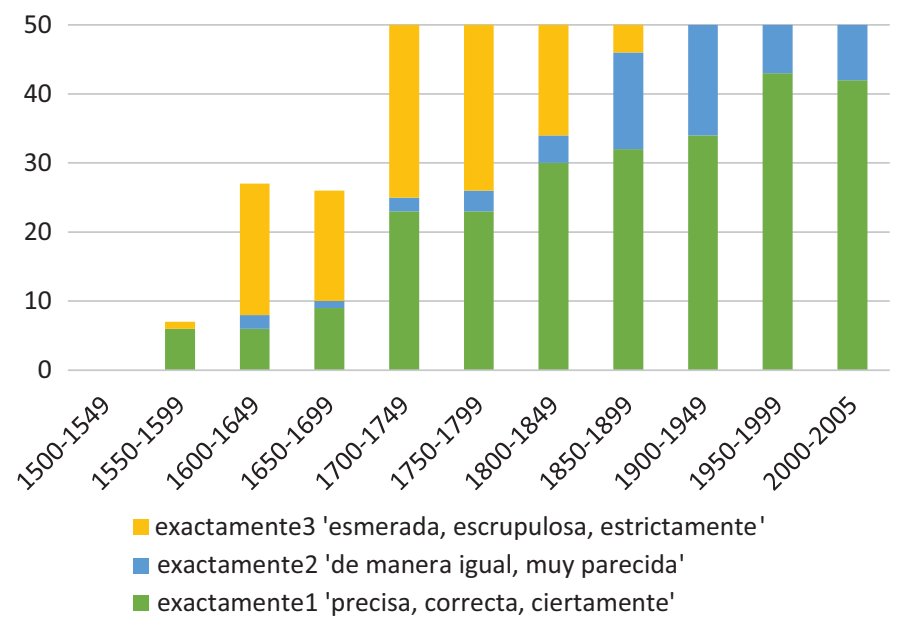

Gráfico 7: Dispersión diacrónica de los significados de exactamente en la muestra base (máx. 50 ejemplos por medio siglo).

En cuanto a las variantes contextuales, observamos una correspondencia bastante paralela entre el adjetivo y el adverbio: en ambos, el tercer uso ('esmerado, escrupuloso y puntual al cumplir una norma $u$ orden') se va perdiendo a favor de los demás usos. El uso 'preciso, correcto, cierto’ es el más frecuente tanto en el adjetivo como en el adverbio.

Entre los cuatro pares léxicos de adjetivos y adverbios analizados, encontramos la mayor correspondencia semántica en exacto y exactamente. Es decir, es el par más «simétrico» desde un punto de vista semántico. Tanto el adjetivo como el adverbio son monosémicos: solo conocen el significado base de exactitud, que desarrolla una serie de variantes contextuales paralelas en el adjetivo y el adverbio. En este caso, el adverbio parece seguir automáticamente al adjetivo. Por último, observamos de nuevo un desarrollo paralelo entre el español exacto/ exactamente y el francés exact/exactement, que adopta las mismas variantes contextuales en los mismos siglos (DHLF 2000, s.v. exact). 